Florida International University FIU Digital Commons

7-3-2014

\title{
Implications of FIN 46 for Accruals Quality and Investment Efficiency
}

Fang Zhao

Florida International University, fzhao002@fiu.edu

DOI: $10.25148 /$ etd.FI14071183

Follow this and additional works at: https://digitalcommons.fiu.edu/etd

\section{Recommended Citation}

Zhao, Fang, "Implications of FIN 46 for Accruals Quality and Investment Efficiency" (2014). FIU Electronic Theses and Dissertations. 1553.

https://digitalcommons.fiu.edu/etd/1553

This work is brought to you for free and open access by the University Graduate School at FIU Digital Commons. It has been accepted for inclusion in FIU Electronic Theses and Dissertations by an authorized administrator of FIU Digital Commons. For more information, please contact dcc@fiu.edu. 


\title{
FLORIDA INTERNATIONAL UNIVERSITY
}

\author{
Miami, Florida
}

\section{IMPLICATIONS OF FIN 46 FOR ACCRUALS QUALITY}

\section{AND INVESTMENT EFFICIENCY}

A dissertation submitted in partial fulfillment of the

requirements for the degree of

DOCTOR OF PHILOSOPHY

in

BUSINESS ADMINITRATION

by

Fang Zhao 
To: Dean David R. Klock

College of Business

This dissertation, written by Fang Zhao, and entitled Implication of FIN 46 for Accruals Quality and Investment Efficiency, having been approved in respect to style and intellectual content, is referred to you for judgment.

We have read this dissertation and recommend that it be approved.

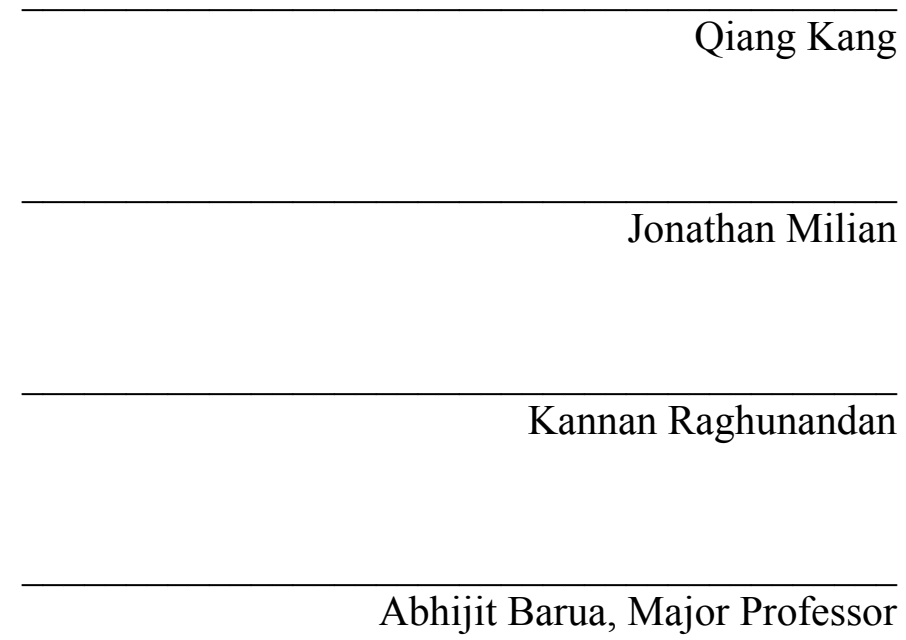

Date of Defense: July 3, 2014

The dissertation of Fang Zhao is approved.

Dean David R. Klock

College of Business

Dean Lakshmi N. Reddi

University Graduate School

Florida International University, 2014 
(C) Copyright 2014 by Fang Zhao

All rights reserved. 


\section{DEDICATION}

This dissertation is dedicated to my husband, Geliang Song, and my mother, Guiying Ye. Without their love and support, the completion of this work would not have been possible. 


\section{ACKNOWLEDGMENTS}

I would like to express my sincere appreciation to my major professor, Dr. Abhijit Barua, for his support throughout my Ph.D. study at Florida International University. Without his tireless guidance, supervision and inspiration, the timely goals of my dissertation would not have been achieved. I would also like to thank him for providing the funding support for the database $10 \mathrm{~K}$ Wizard.

I would like to thank my committee members Dr. Qiang Kang, Dr. Jonathan Milian, Dr. Kannan Raghunandan and Dr. Abhjit Barua for their precious time and valuable comments. I would also like to thank Dr. Jonathan Milian for his suggestions on my writing.

I would like to express my sincere gratitude to Dr. Ruth Ann Mc Ewen, Director of the School of Accounting at FIU, for her trust and support.

I would like to thank Dr. Jianbin (Vincent) Zhu, Statistical Consultant at the FIU Graduate School, for his statistical assistance. I would like to acknowledge Jeanette Garcia, Katie Pacheco and Jessica Pinon, the consultants at the FIU Center for Excellence in Writing, for their suggestions on my writing.

I would like to thank all my family and friends for their encouragement and support throughout the whole dissertation process and my Ph.D. study. 


\section{ABSTRACT OF THE DISSERTATION \\ IMPLICATIONS OF FIN 46 FOR ACCRUALS QUALITY \\ AND INVESTMENT EFFICIENCY}

by

Fang Zhao

Florida International University, 2014

Miami, Florida

Professor Abhijit Barua, Major Professor

The Financial Accounting Standards Board (FASB) issued Interpretation No. 46 (FIN 46), Consolidation of Variable Interest Entities - An Interpretation of ARB No. 51, in January 2003 and revised it in December 2003, with the objective to improve the transparency of financial information. Under FIN 46, companies are required to consolidate variable interest entities (VIEs) on financial statements if they are the primary beneficiaries of the VIEs. This dissertation empirically examines whether the implementation of this new financial reporting guidance affects firms' accruals quality and investment efficiency. A manually collected sample comprised of firms affected by FIN 46 and firms disclosing no material impact from FIN 46 is used in the empirical analyses.

The first part of the dissertation investigates the effects of FIN 46 on accruals quality. By using different accrual quality measures in prior studies, this study found that firms affected by FIN 46 experienced a decrease in accrual quality compared to firms reporting no material impact from FIN 46. Among the firms affected by FIN 46, firms consolidating VIEs were compared with firms terminating or restructuring VIEs. The 
accruals quality of firms consolidating VIEs was found to be lower than that of firms terminating or restructuring VIEs. These results are consistent in tests using alternative control samples.

The second part of this dissertation examines the effects of FIN 46 on investment efficiency. Mixed results were found from using two different proxies used in prior literature. Using the investment-cash flow sensitivity to proxy for investment efficiency, firms affected by FIN 46 experienced a decrease in investment efficiency compared to firms reporting no material impact. It was also found that higher investment-cash flow sensitivity for firms consolidating VIEs during post-FIN 46 periods compared to both the no-impact firms and the matched pair control sample. Contrasting results were found when the deviation from expected investment is used as another proxy for investment efficiency. Empirical analyses show that FIN 46 firms experienced improved investment efficiency measured by the deviation from expected investment after their adoption of FIN 46. This study also provides explanations for the opposite results from the two different proxies. 
CHAPTER

PAGE

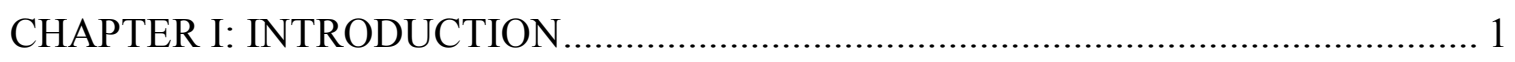

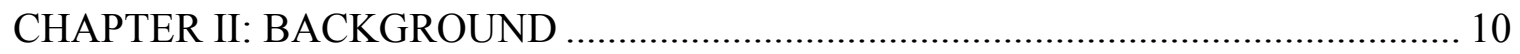

CHAPTER III: IMPLICATIONS OF FIN 46 FOR ACCRUALS QUALITY................ 13

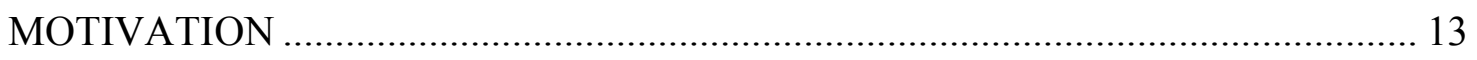

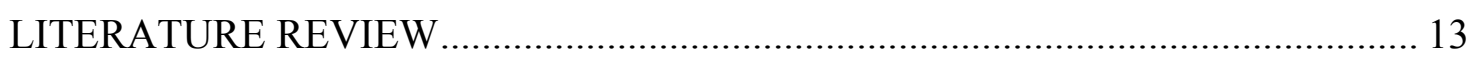

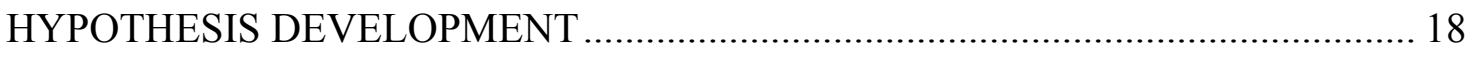

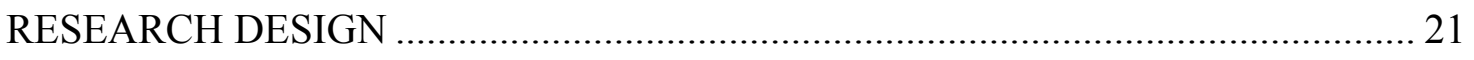

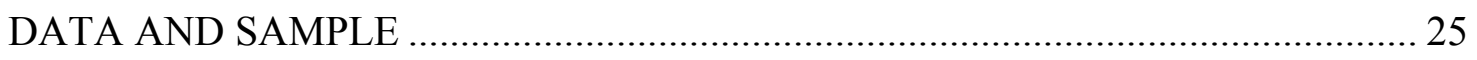

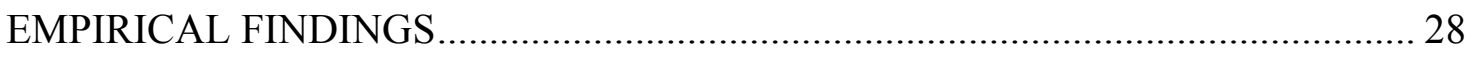

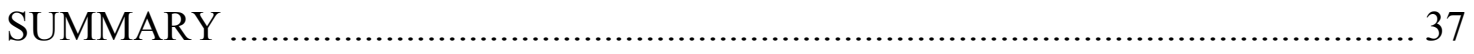

CHAPTER IV: IMPLICATIONS OF FIN 46 FOR INVESTMENT EFFICIENCY ....... 39

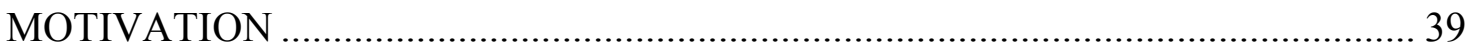

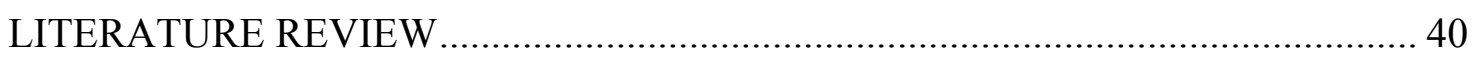

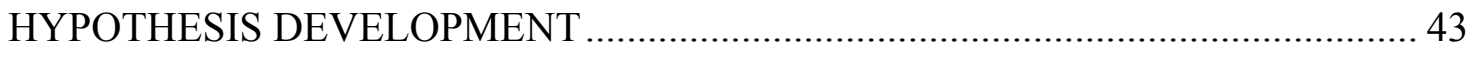

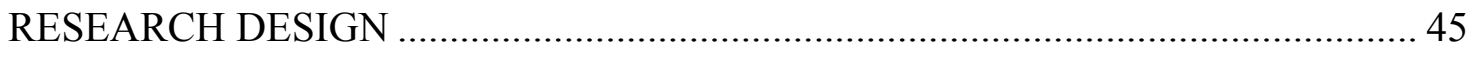

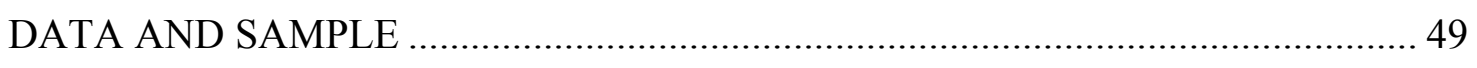

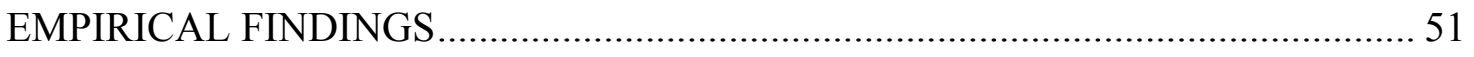

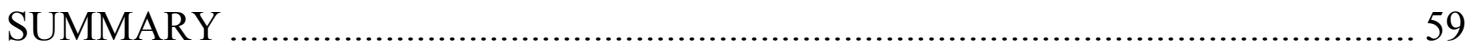

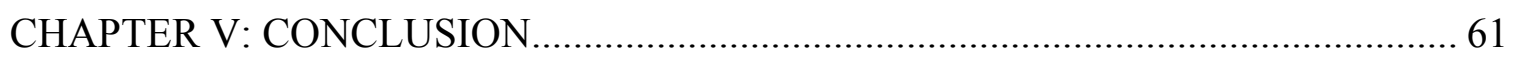

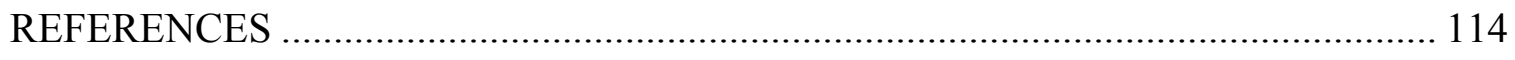

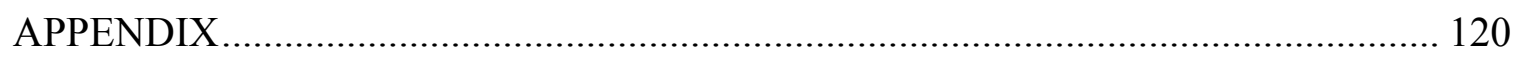

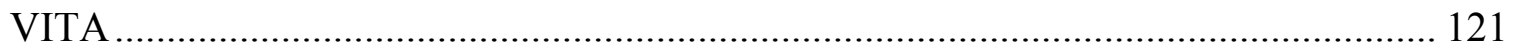




\section{LIST OF TABLES}

TABLE

PAGE

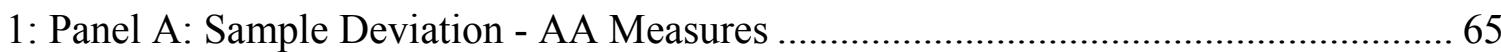

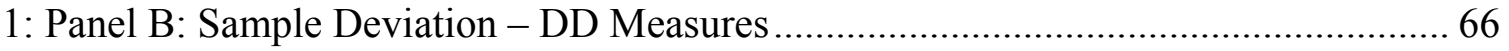

2: Panel A: Descriptive Statistics - Sample for AA Measures....................................... 67

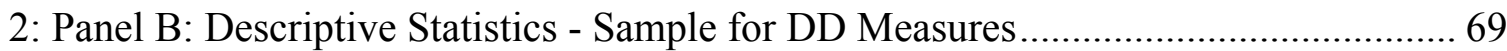

3: Regression of Absolute Value of Performance-Matched Abnormal Accruals (H1) .... 71

4: Regression of Accrual Estimation Errors (H1) ..................................................... 73

5: Regression of Standard Deviation of Accrual Estimation Errors (H1) ...................... 74

6: Regression of Absolute Value of Performance-Matched Abnormal Accruals (H2) .... 75

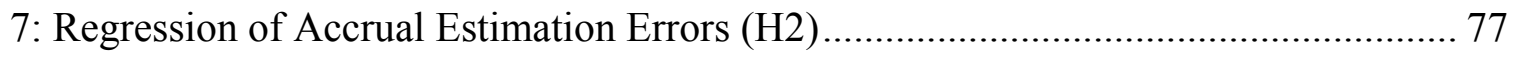

8: Regression of Standard Deviation of Accrual Estimation Errors (H2) ..................... 79

9: Panel A: Additional Analysis of H1 - FIN 46 Firms and Matched Pairs .................... 81

9: Panel B: Additional Analysis of H1 - FIN 46 Firms and Matched Pairs..................... 83

10: Additional Analysis of H2 - Group 1 and Matched Pairs........................................ 85

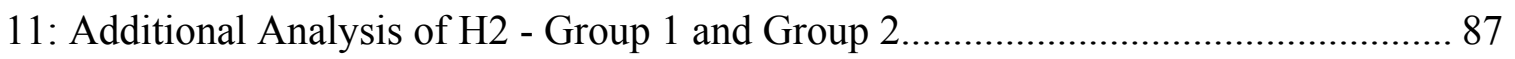

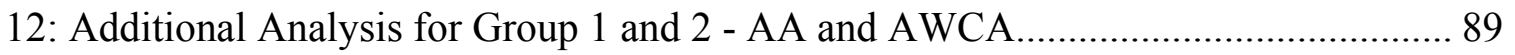

13: Additional Analysis for Group 1 and 2 - PMAA and PMAWCA ............................. 90

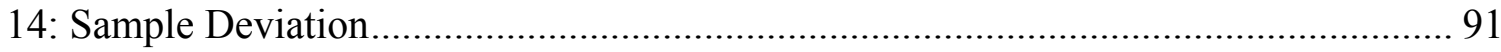

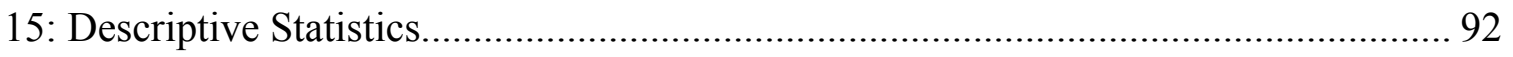


16: Multivariate Regression Results for Investment-Cash Flow Sensitivity

17: Regression Results for H3: Investment-Cash Flow Sensitivity - FIN 46 Firms and Matched Pairs 95

18: Deviation from Expected Investment Analyses: FIN 46 Firms and Matched Pairs ... 96

19: Additional Analysis of H3 - FIN 46 Firms and Matched Pairs 98

20: Regression Results for H4 Investment-Cash Flow Sensitivity - Group 1 vs.

Group 2 101

21: Investment Efficiency: Firms consolidating VIEs versus Firms

Terminating/Restructuring VIE H4 - Matched Pairs 102

22: Additional Analysis of H4 - Group 1 and Matched Pairs. 105

23: Additional Analysis of H4 - Group 1 and Matched Pairs. 107

24: Regression Results for H1 - Investment-Cash Flow Sensitivity - Constrained and Unconstrained Groups 110

25: Regression Results for H1 - Investment-Cash Flow Sensitivity - FIN 46 Firms and Matched Pairs 112 


\section{CHAPTER I: INTRODUCTION}

The Enron Scandal in 2001 uncovers the financial reporting problems related to off-balance sheet debts and undisclosed losses from income statements by using special purpose entities (SPEs). In response to the widespread misuse of the consolidation rules relating to SPEs, the Financial Accounting Standards Board (FASB) issued Interpretation No. 46 (FIN 46), Consolidation of Variable Interest Entities - An Interpretation of ARB No. 51, in January 2003 and revised it in December 2003, with the objective to improve the transparency of financial information. ${ }^{1}$ Under FIN 46, companies are required to consolidate SPEs on the financial statements if they are the primary beneficiaries of the SPEs, regardless of their voting interests in the entities. ${ }^{2}$ This study investigates whether the implementation of this new guide affects accruals quality and investment efficiency of firms impacted by FIN 46.

The first part of my dissertation examines the effects of FIN 46 on accruals quality. By using SPEs, firms gain more flexibility to manage reported earnings and debts since sponsoring firms control both entities. Prior studies provide evidence that firms manage earnings through off-balance sheet items (e.g., Dechow and Shakespeare 2009; Feng et al. 2009; Dechow et al. 2010). Dechow and Shakespeare (2009) find that firms manage earnings by timing securitizations of assets by using SPEs. Feng et al. (2009) document that SPEs created for financial reporting purposes are more likely to be used to manage earnings. Their tests all focus on the pre-FIN 46 periods. Since FIN 46 mandates new consolidation rules and disclosure provisions for firms with SPEs, resultant

\footnotetext{
${ }^{1}$ The revised version is FIN 46 (R). In this paper, I use FIN 46 to refer to both FIN 46 and FIN 46 (R).

${ }^{2}$ SPE is the general term for the off-balance sheet special purpose entities. SPEs subject to FIN 46 are named variable interest entities (VIEs) under FIN 46.
} 
enhanced transparency is expected to decrease opportunistic earnings management (Lobo and Zhou 2001; Hunton et al. 2006), thus improving the accrual quality. However, the accrual quality of firms impacted by FIN 46 may also deteriorate. Previous studies show that when one method of earnings management becomes costly or restrained, firms will resort to alternative ways to manage earnings (e.g., Zhang 2012; Chi et al. 2011). When firms are affected by FIN 46 and their VIEs are consolidated, they lose the reporting flexibilities that could be used to manage earnings. Impacted firms may resort to other methods, such as manipulating accounting accruals, in order to manipulate earnings on the consolidated financial statements. Thus, it is an empirically open question whether the implementation of FIN 46 has improved or deteriorated the accrual quality of affected firms.

To address this question, I compared accruals quality of firms affected by FIN 46 before and after the implementation of this accounting pronouncement. I used a manually identified sample of firms by examining their SEC filings (i.e., 10-K and 10-Q) and form three groups: (1) consolidation (on-book) group - consists of firms that have consolidated VIEs on their financial statements, (2) off-book group - consists of of firms that have restructured or terminated VIEs to avoid consolidation, and (3) no material impact group - consists of firms that have disclosed no material impact from FIN 46. In most analyses, I compared the accruals quality of consolidation group and off-book group while using no-material impact group as a control. In addition, I also used a matched pair control group to check the robustness of my results. I employed a difference-in-differences approach to test the difference in accruals quality between pre-and post-implementation of FIN 46. In pre-post tests, I used a sample period of four years before and four years 
after the implementation of FIN 46. I conducted tests using three different sets of accrual quality measures: the absolute value of abnormal accruals, accruals estimation errors, and the standard deviation of accruals estimation errors. For abnormal accrual measures, I measured performance-matched abnormal total accruals and working capital accruals following Kothari et al. (2005). In order to measure accrual estimation errors I used the Dechow and Dichev (2002, DD model hereinafter) model and the modified version of DD model suggested by McNichols (2002, modified DD model hereinafter) as applied by Francis et al. (2005).

I find that firms affected by FIN 46 (i.e., firms either consolidating VIEs or terminating/restructuring VIEs), compared to firms reporting no material impact from FIN 46, experienced lower quality of accruals, measured by the accrual estimation errors from the modified DD model, the standard deviation of the residuals from the DD model, and modified DD model. In the additional analysis, I replaced the control sample with a matched pair sample. I find consistent results using the accrual quality measured by absolute accrual estimation errors and the standard deviation of the residuals from the modified DD model.

When it comes to the differences between the two subgroups in the FIN 46 firms (firms consolidating VIEs and firms terminating or restructuring VIEs), the results consistently show that the accrual quality of firms consolidating VIEs (group 1) are lower compared to that of firms in group 2, no matter which control sample is used. The differential change in accrual quality between the two groups can be partially attributed to the facts that group 1 has pressure to manage earnings when the consolidation brings 
negative effects on earnings. This prediction is confirmed by the empirical tests using signed abnormal accrual measures.

The results of the first part of the dissertation help us understand the changes in accrual quality for firms impacted by FIN 46. Although the consolidation process and improved disclosure may constrain earnings management through previously used offbalance sheet SPEs, firms may resort to other methods that bypass VIEs to manipulate earnings, thus worsening the accrual quality in the post-FIN 46 periods.

Findings in the first part of this dissertation contribute to the literature in the following ways. First, my study adds to the literature on the impact of FIN 46 on financial reporting. Prior studies investigate the economic consequences of FIN 46 from the perspective of market participants' responsiveness such as cost of capital (Callahan et al. 2012), analyst forecast precision, and earnings response coefficients (Gurun et al. 2012). While these studies largely assume that the implementation of FIN 46 enhances financial reporting transparency and deters earnings management, no extant research examines the impact of the changes in SPE consolidation rules on the quality of reported accounting numbers. This study fills this void by examining the effects of FIN 46 on accrual quality. Second, this study contributes to the stream of studies on off-balance sheet items in general. While prior studies provide evidence that firms with SPEs manage earnings through off-balance sheet activities, this study extends prior research by testing whether the changes in rules related to SPEs affect the quality of accruals. Third, this study contributes to the literature that examines how mandatory changes in accounting standards affect financial reporting quality. 
In the second part of the dissertation, I focus on the effects of FIN 46 on investment decisions made by affected firms. More specifically I examine the investment efficiency of affected firms during the pre- and post-FIN46 periods. This particular question is important for several reasons. First, the implementation of FIN 46 may have significant influence on financial reporting quality that includes quality of reported accounting numbers (i.e., accruals quality) and quality of disclosures. Second, FIN 46 is likely to reduce affected firms' financial flexibility by eliminating the opportunity to use certain off-balance sheet items, thus creating financial constraints. Prior studies show that investment efficiency is associated with quality of financial reporting as well as with financial constraints (e.g., Biddle and Hilary 2006; Biddle et al. 2009). Thus, FIN 46 provides a unique setting to test how the implementation of the accounting guide affects investment efficiency.

An important determinant of firms' economic productivity and future performance is investment efficiency, which can be affected by accounting information quality. Poor accounting quality (such as the opaqueness of accounting information caused by the use of off-balance sheet items) exacerbates information asymmetry between firms and investors. Prior research suggests that information asymmetry can create either liquidity constraints or excess liquidity, both of which are associated with investment inefficiency (Biddle and Hilary 2006). While the implementation of FIN 46 likely affects financial information quality, it may also impose indirect restrictions on certain off-balance sheet financing, which in turn affects real investment activities (Bens and Monahan 2008). Thus, this study addresses an empirically open question of whether FIN 46 improves investment efficiency. 
To examine the effects of FIN 46 on investment efficiency, I compare firms affected by FIN 46 before and after the implementation of this accounting pronouncement by using the same sample and classifications for tests and control groups as used in the first part of the dissertation. More specifically, I compare investment efficiency of the consolidation group and the off-book group between pre-and postFIN46 periods, using no material impact group as the control. In addition, I use a matched-pair control sample to test the robustness of the results. I use two different sets of measures for investment efficiency that are applied in the literature. First, I use investment-cash flow sensitivity as a proxy for investment efficiency following Biddle and Hilary (2006). Although there are debates on the investment-cash flow sensitivity measure in the Finance literature (i.e.,Kaplan and Zingles 1997, Fazzari et al. 2000, etc.), I use this measure to explain a different dimension of investment efficiency. Second, I use the absolute value of deviations from expected level of investment as a measure of investment efficiency. The expectation models from prior literature (e.g., Chen et al. 2011) are used to derive this measure.

I find mixed results from using two different proxies for investment efficiency in this study. Using the investment-cash flow sensitivity measure to proxy for investment efficiency, where higher sensitivity implies lower efficiency, I find firms affected by FIN 46 experienced decreased investment efficiency indicated by increased investment sensitivity to cash flows. The control sample in the tests consists of firms reporting no material impact from FIN 46.The same results are found using matched pairs as another control sample of FIN 46 firms. I also find the investment of firms consolidating VIEs is 
more sensitive to cash flows after their adoption of FIN 46, compared to both the noimpact firms and matched pairs.

I find contrasting results when I use the deviation from expected investment as a proxy for investment efficiency. When comparing FIN 46 firms and their matched pairs, I find that FIN 46 firms experience improved investment efficiency measured by the deviation from expected investment after their adoption of FIN 46. Furthermore, I find firms consolidating VIEs experience improved investment efficiency measured by the deviation from expected investment after FIN 46, compared to their matched peers. However, firms restructuring or terminating their VIEs do not exhibit such improvement. The complete opposite results from using the two different proxies warrant further explanations. One possible explanation could be investment-cash flow sensitivity may be capturing different dimensions of investment decision compared to the deviation from expected investment. Another possible explanation could be the effects of the financial constraints faced by firms affected by FIN 46, because firms that are no longer allowed to use off-balance sheet financing may have less financing flexibility. To explore the possibility, I redo investment-cash flow sensitivity tests by splitting the test sample based on financial constraints and find evidence that the higher investment-cash flow sensitivity is driven by financial constraints.

The second study in the dissertation contributes to the literature by extending a relatively small but growing stream of research on how the quality of accounting information affects investment efficiency. It also contributes to the literature on the economic consequences of FIN 46. 
I organize the remaining sections as follows. Chapter II provides the background of this study. I introduce the definitions of special purpose entities (SPEs) and variable interest entities (VIEs). I also provide the descriptions of FIN 46 and FIN 46 (R) with its application scope, important terms, and effective dates.

Chapter III is the first study of the dissertation, which examines the effects of FIN 46 on accruals quality. I measure accruals quality using several extensively used proxies in the literature like Dechow and Dichev (2002), McNichols (2002) and Francis et al. (2005). I find that compared to firms reporting no material impact from FIN 46, firms impacted by FIN 46 experience worsened accruals quality after consolidating, terminating or restructuring VIEs. The accruals quality is measured by the accrual estimation errors in the modified DD 2002 model $\left(A B S \_M D D\right)$ and the standard deviation of the residuals in the DD 2002 model and its modified version (STD_DD and STD_MDD), Furthermore, among firms impacted by FIN 46, firms consolidating VIEs experience lower accrual quality proxied by these measures, compared to firms terminating or restructuring VIEs.

Chapter IV is the second study of my dissertation, which examines the effects of FIN 46 on investment efficiency. Measuring investment efficiency using the deviation from expected investment (Chen et al. 2011), the empirical results show that firms affected by FIN 46 experience improved investment efficiency after the adoption of FIN 46, compared to a sample of matched firms that are not affected by FIN 46. Among these FIN 46 firms, firms consolidating VIEs experience greater improvement than those restructuring or terminating VIEs. However, when measuring investment using investment-cash flow sensitivity, I find opposite results. 
Chapter V concludes this dissertation. In this chapter, I summarize the two studies in the dissertation, describe the contributions, and discuss potential limitations 


\section{CHAPTER II: BACKGROUND}

In this chapter, I discuss the background of accounting guidance relating to special purpose entities (SPEs) and variable interest entities (VIEs). I provide descriptions of FIN 46 and FIN 46 (R) with its application scope, important terms in the standard and its effective dates.

\section{Special Purpose Entities (SPEs)}

SPEs are subsidiaries created for a limited purpose, with a limited life and limited activities, and designed to benefit their sponsoring companies. SPEs were best known for their use in leasing and asset securitization transactions (SEC, 2005). Although used in accounting practice in the early 1980s, SPEs received very limited attention from the academic and professional accounting literature until Enron's scandal in 2001, which revealed many concerns related to SPEs (Hartgraves and Benston 2002). SPEs usually have the legal forms of partnership, trust, joint venture or corporation.

The main applications of SPEs in early years include off-balance sheet securitizations, long-term lease and research and development (R\&D) funds. Generally, special purpose entities have the following characteristics: thinly capitalized; no independent management or employees; a trustee serving as the intermediate between the SPE and the sponsoring company by performing administrative functions (Soroosh and Giesielski 2004).

Before the implementation of FIN 46, U.S. GAAP requires the consolidation of SPEs based solely on voting rights. Specifically, the sponsor of SPEs does not need to consolidate if a third party residual equity investment at risk is at least three percent of the SPE's total capital. 


\section{FIN 46 and FIN 46 (R)}

In 2003, FASB issued interpretation No. 46, Consolidation of Variable Interest Entities-An Interpretation of ARB No. 51 (FIN 46), in January and revised it in December. The revised version is FIN 46 (R). FIN 46 "clarifies the application of Accounting Research Bulletin No. 51, Consolidated Financial Statements, to certain entities in which equity investors do not have the characteristics of a controlling financial interest or do not have sufficient equity at risk for the entity to finance its activities without additional subordinated financial support” (FASB, 2003).

FIN 46 mandates consolidation by setting criteria on whether the sponsor is the primary beneficiary of the SPEs, instead of depending on the voting interest. Primary beneficiary is the party that absorbs the majority of the expected residual return or the expected losses of the SPE it sponsors. ${ }^{3}$ FIN 46 also increases the consolidation threshold of third party investments from three percent to ten percent.

The SPEs that are affected by FIN 46 are called Variable Interest Entities (VIEs), and should be consolidated by their primary beneficiaries. FIN 46 also mandates new disclosure requirements for sponsoring firms that have significant interests in VIEs (FASB, 2003).

\section{Variable Interest Entities (VIE)}

FIN 46 defines "variable interest" as "contractual, ownership, or other pecuniary interests in an entity that change with changes in the fair value of the entity's net assets

\footnotetext{
${ }^{3}$ The absorption of expected losses is a more important condition than the absorption of expected return when evaluating whether a party is the primary beneficiary. In the cases when one party absorb the majority of the expected return of a VIE, while another party absorb the majority of the expected losses, the lesser should be considered the primary beneficiary of the VIE and thus should consolidate the VIE (FASB, 2003).
} 
exclusive of variable interests" (FASB, 2003). This includes "equity interests, debt obligations, leases, royalties or other contracts, and monetary interests in an entity that changes as the entity's net assets value fluctuates" (PricewaterhouseCoopers, 2004). Variable interest entities are the SPEs that are subject to FIN 46 and need to be consolidated by their primary beneficiaries.

\section{Effective Dates}

FIN 46 (R) are applied to SPEs no later than as of the end of the first reporting period that ends after December 15, 2013 (as of December 31, 2013 for firms with calendar-year reporting periods) for public companies (FASB, 2003). For nonpublic companies, FIN $46(\mathrm{R})$ is applied to all the entities subject to this interpretation by the beginning of the first annual period beginning after December 15, 2004 (FASB, 2003).

In practice, some firms chose to early adopt FIN 46 when it was first issued in January 2003 (before the revision in December, 2013). 


\section{CHAPTER III: IMPLICATIONS OF FIN 46 FOR ACCRUALS QUALITY}

\section{MOTIVATION}

This study investigates whether the implementation of this new guidance affects accrual quality of firms impacted by FIN 46. By using SPEs, firms gain more flexibility to manage reported earnings and debts since sponsoring firms control both entities. Prior studies provide evidence that firms manage earnings by using off-balance sheet items (e.g., Dechow and Shakespeare 2009; Feng et al. 2009; Dechow et al. 2010). Dechow and Shakespeare (2009) find that firms manage earnings by timing securitizations of assets by using SPEs. Feng et al. (2009) document that SPEs created for financial reporting purpose are more likely to manage earnings. Their tests all focus on the pre-FIN 46 periods. Since FIN 46 mandates new consolidation rules and disclosure provisions for firms with SPEs, resultant enhanced transparency is expected to decrease opportunistic earnings management (Lobo and Zhou 2001; Hunton et al. 2006), thus improve the accrual quality. However, the accrual quality of firms impacted by FIN 46 may deteriorate. Previous studies show that when one method of earnings management becomes costly, firms will resort to alternative ways to manage earnings (e.g., Zhang, 2012; Chi et al. 2011). When VIEs are consolidated, firms may resort to other methods that bypass the VIEs to manipulate earnings to window-dress the accounting numbers on the consolidated financial statements. Therefore, it is worthwhile to disentangle how the accrual quality changes for firms impacted by FIN 46.

\section{LITERATURE REVIEW} Special Purpose Entities (SPEs) and Earnings Management 
SPEs that are kept off the financial statements can be used not only to hide debt, but also to manage earnings (SEC, 2005). Feng et al. (2009) identify the determinants of using SPEs in a large cross-temporal sample. SPEs can be set up for financial reporting, economic and tax purposes. They also find that SPEs arranged for financial reporting purposes are associated with earnings management. While their sample period ranges from 1997 to 2004, they do not examine whether the use of SPEs to manage earnings changes after the implementation of FIN 46. Dechow and Shakespeare (2009) investigate earnings management behavior by focusing on a particular group of SPEs that are used for asset securitizations. They document that a significantly higher volume of securitization transactions occur in the last few days of the quarter during the first three quarters taking advantage of relax disclosure requirements for the quarterly financial reporting. They find these transactions are associated with incentives for earnings management. Dechow et al. (2010) also provide evidence consistent with firms with SPEs managing earnings by using flexibility available in accounting rules.

\section{Impact of FIN 46}

Callahan, Smith and Spencer (2012) find that firms with VIEs affected by FIN 46 experience increases in the cost of equity capital compared to firms reporting no material impact from the standard. They also find that firms consolidating VIEs experience larger increases in cost of capital compared to those keeping VIEs off the financial statements through restructuring or termination.

Callahan and Spencer (2012) focus on firms that are not the primary beneficiary but hold a significant variable interest in a variable interest entity (VIE) to examine the value relevance of the disclosure made under FIN 46 of these firms. FIN 46 requires such 
firms to make additional disclosures about the off-balance sheet VIEs like firm's maximum amount at risk, even though they don't need to consolidate the VIEs. They find the maximum risk disclosures were only marginally priced. They also examine the differential impact of off-balance sheet disclosure required by FIN 46 and the Management's Discussion and Analysis (MD\&A) disclosure required by SOX. They find additional improvement in firm idiosyncratic risk for firms disclosing interests in VIEs under FIN 46. Dickinson et al. (2010) examine the market reaction of FIN 46 and find that from investors' perspective, the cost of complying with FIN 46 significantly outweighs the intended improvements in the accounting information quality. However, investors think that the information quality is improved for highly levered firms. Gurun et al. (2012) find that firms affected by FIN 46 are perceived by the market as having higher information risk. However, there is no such reaction for information users who have access to off-balance sheet debt structure information prior to 2001. Luo and Warfield (2014) examined the impact of FIN 46 on firms' earnings informativeness. They partition firms into two groups based on their likelihood to manipulate earnings before FIN 46. For firms that manipulated earnings less using SPEs before FIN 46, the perceived earnings informativeness measured by earnings response coefficient (ERC), while no such improvement is found for other firms. They also find that firms restructuring VIEs experience differential market reaction compared to other VIE firms. Bonsall and Bozanic (2012) find that consolidated VIEs are associated with less information asymmetry than unconsolidated VIEs, suggesting that there are potential hidden risks of the unconsolidated VIEs. The information asymmetry is reduced after consolidating VIEs through the adoption of FIN 46. 
Zhang (2009) examine the economic consequences of FIN 46. She finds that credit ratings for VIEs worsened after FIN 46 and that the pricing of information risk decreased for non-VIE firms, but not for VIE firms.

There are some prior studies that focus on certain categories of off-balance sheet items impacted by FIN 46. Synthetic leases are a common off-balance sheet item since they were qualified as operating lease before FIN 46. According to FIN 46, lessee companies should consolidate synthetic leases if they are held by SPEs classified as VIEs under the terms of FIN 46 (Danvers et al. 2003). Callahan, Smith and Spencer (2013) focus on firms with synthetic leases impacted by FIN 46 to examine the change in market valuation and related measurement reliability of these firms after FIN 46. They find that the synthetic lease liabilities recognized in the financial statements, as required by FIN 46 , are valued with greater weight by the market than are those disclosed in the notes before FIN 46. This differential valuation effect is associated with the perceived measurement reliability across the adoption of FIN 46.

Another common form of off-balance sheet SPEs are asset-backed commercial papers (ABCPs). They are backed by receivables of companies and then issued by banks to investors as a short-term investment vehicle. The financial statements of ABCPs were not reported by the sponsors before FIN 46. According to the FIN 46 definitions, many of the ABCPs are VIEs and their sponsors become the primary beneficiary, which are required to consolidate ABCPs on the financial statements. Bens and Monahan (2008) find that the use of asset-backed commercial paper (ABCP) declined after FIN 46 and the decline is caused by the decrease in the ABCP sponsors. Banks in North America engaged in restructuring to avoid consolidating $\mathrm{ABCPs}$ on the financial statements. 


\section{Accrual Quality}

One of the most widely used accrual quality metrics is proposed by Dechow and Dichev (2002), who suggested measuring accrual quality as the standard deviation of the residuals from firm-specific regressions of changes in working capital on past, present, and future operating cash flows. This measure is adjusted by McNichols (2002) and Francis et al. (2005) to include current year change in sales and current year property plant and equipment so that it is linked with the discretionary accruals model derived by Jones (1991). Accrual quality carries the information about the mapping of earnings and cash flows. The poorer the accrual quality is, the more information risk exists in the accounting information (Francis et al. 2005). This measure has been extensively used in accrual quality literature (e.g., Barua et al. 2010).

Prior studies also use other metrics to evaluate the quality of accruals. For example, the abnormal total accruals estimated using the modified Jones model (Dechow et al. 1995); performance-matched abnormal accruals (Francis et al. 2005). In this paper, I use all of these metrics to measure accrual quality to test the impact of FIN 46 on the accrual quality for firms adopted the standard.

Prior studies find that accrual quality is related to cost of equity. Francis et al. (2004) find that firms with the least favorable earnings attributes experience a higher cost of equity than firms with the most favorable earnings attributes. Among the seven attributes they examined, accrual quality is associated with the largest cost of equity effects. Francis et al. (2005) examine the market pricing of accrual quality and find that less favorable accrual quality is associated with higher cost of debt and equity, suggesting accrual quality captures the information risk perceived by investors. 


\section{HYPOTHESIS DEVELOPMENT}

Although SPEs are used by sponsoring firms predominantly to keep assets and obligations off-balance sheet for arranging external financing, they also provide managers with potential earnings management opportunities. For example, managers opportunistically time the recognition of gains on securitizations and use their discretion in the process of estimating gains or losses. Firms using SPEs to frame lease transactions can exercise discretion on fixing selling prices of assets, timing of asset transferring, recognition of depreciation and impairments etc. Similarly firms with research \& development partnership can manage reported $R \& D$ expenses.

Feng et al. (2009) use a relatively bigger sample and provide evidence that SPEs arranged for financial reporting purposes are associated with earnings management. Their data period is from 1997 to 2004 and they didn't examine whether the use of discretionary accruals to manage earnings changes for VIE firms after FIN 46. Dechow and Shakespeare (2009) investigate whether firms manage earnings by using gain on securitizations of assets by using SPEs. They document that a significantly higher volume of securitization transactions occur in the last few days of the quarter during the first three quarters taking advantage of relax disclosure requirements for the quarterly financial reporting. They find these transactions are associated with incentives for earnings management. Dechow et al. (2010) also provide evidence consistent with firms with SPEs manage earnings by using flexibility available in accounting rules.

Firms with VIEs subject to FIN 46 respond to the standard by consolidating VIEs on the financial statements, or restructuring VIEs to avoid consolidation or terminating VIEs. In each case, the earnings management using VIEs can be mitigated. Besides, 
increased disclosure improves accounting transparency and reduces information asymmetry, firms tend to engage in less earnings management and thus improve quality of accruals (Lobo and Zhou, 2001). However, the provision of FIN 46 can also be associated with more earnings management. The consolidation rules of VIEs result in not only increases in both assets and liabilities of the sponsoring firms, but also increases in the depreciation expenses of the fixed assets and interest expenses of the debts, which were previously kept away from the income statement. Thus consolidation of SPEs may lead to a decrease in net income. Due to the decrease in the accounting rate of returns, managers may have incentives to manage earnings upward.

Since the off-balance sheet SPEs were used to manage earnings, consolidating them on the financial statements or terminating them make firms lose such channels to manipulate earnings, thus the earnings may be manipulated in other ways that cannot be kept off the books any more. On the other hand, earnings management can be achieved using different methods including manipulating accruals or real activities, and there is a trade-off between these two methods, that is, if the costs of one method increase, firms may switch to another method to manage earnings (Zhang, 2012). If SPEs are used more for real-activity earnings management, firms consolidating or terminating previously offbook SPEs will lose the shelter for such earnings management, they may resort to more accrual-based earnings management.

Considering the discussion above on the possibility of decreasing or increasing earnings management, I expect FIN 46 may affect either direction of the change in accrual quality. More formally, my hypothesis is as follows: 


\section{H1: $\quad$ Firms with VIEs experience a change in accrual quality after FIN 46}

compared to firms reporting no material impact by the standard.

Among the firms with VIEs under FIN 46, some respond to the standard by consolidating their VIEs on the financial statements, while some respond by restructuring or disposing of the VIEs so that they can keep the VIEs off books. Callahan et al. (2012) find that firms consolidating VIEs experience a differential effect on cost of capital compared to those that restructure or divest VIEs. It is worthwhile to examine whether there are differential effects of FIN 46 on the accrual quality between the two groups.

Firms consolidating VIEs on their financial statements provide more detailed accounting information about the VIEs to the public than those keeping VIEs off the books. Feng et al. (2009) find that the use of SPEs is associated with earnings management using discretionary accruals. Consolidating VIEs that were previously kept off the balance sheet is expected to decrease the opportunities of accrual-based earnings management for the sponsoring firms.

Compared to the consolidating firms, firms keeping the VIEs off the books still have opportunities to manipulate earnings through VIEs. These firms normally incur restructuring charges that represent continuing costs since they need to provide continuous services for the third party to which the VIEs are shifted to (Bens and Monahan 2008), such ongoing costs may make firms have incentives to smooth earnings after FIN 46.

Therefore, different responses after the adoption of FIN 46 between the two groups may have different impacts on their accrual quality. My second hypothesis is: 
H2: $\quad$ Firms consolidating VIEs experience a differential change in accrual quality compared to firms keeping VIEs off books by restructuring or terminating.

\section{RESEARCH DESIGN}

\section{Accrual Quality Measures}

I use several different accrual quality measures used in prior studies to conduct my empirical analyses.

My first accrual quality measure is the absolute value of performance-matched abnormal accruals as suggested by Kothari et al. (2005) based on the modified Jones model (Dechow et al. 1995).

$$
T A_{t}=\alpha_{0}+\alpha_{1}\left(1 / A_{t-1}\right)+\alpha_{2}\left(\Delta R E V_{t}-\Delta R E C_{t}\right)+P P E_{t}+\varepsilon_{t}
$$

Where:

$T A_{t}=$ total accruals in year $\mathrm{t}$, measured as the difference between income before extraordinary items and operating cash flows, scaled by lagged total assets;

$A_{t-1}=$ total assets in year $\mathrm{t}-1$;

$\triangle R E C_{t}=$ current year change in receivables scaled by lagged total assets;

$\Delta R E V_{t}=$ current year change in sales scaled by lagged total assets;

$P P E_{t}=$ current year level of property, plant and equipment scaled by lagged total assets.

I estimate equation (1) by industry-year. The residual from equation (1) is the abnormal total accruals. Then I adjust the abnormal total accruals using the performance match method used in Francis et al. (2005). First, I form the ROA deciles (performance deciles) for each industry and year, then calculate median abnormal total accruals for each decile. 
The difference between abnormal total accruals and the median abnormal total accruals is the performance-matched abnormal total accruals. I use the absolute value of the performance matched abnormal total accruals $\left(A B S_{-} P M A A\right)$ as my first measure of accrual quality.

I also estimate the abnormal working capital accruals and use the absolute value of the performance matched abnormal working capital accruals $\left(A B S \_P M A W C A\right)$ as my second measure of accrual quality.

$$
W C_{t}=\alpha_{0}+\alpha_{1}\left(1 / A_{t-1}\right)+\alpha_{2}\left(\Delta R E V_{t}-\Delta R E C_{t}\right)+\varepsilon_{t}
$$

Where:

$$
\begin{aligned}
W C_{t}= & \text { working capital accruals, calculated as total accruals plus depreciation and } \\
& \text { amortization. }
\end{aligned}
$$

Other variables have been defined above. The residuals in equation (2) are the abnormal working capital accruals. I get the performance-matched abnormal working capital accruals $\left(A B S \_P M A W C A\right)$ following similar process as that of total accruals described before.

The next two sets of accrual quality measures are based on the accruals estimation error model developed by Dechow and Dichev (2002, DD Model hereinafter). Accruals estimation errors are derived from the following model that specifies working capital accruals as a function of previous, current and future period operating cash flow realizations.

$$
\Delta W C_{t}=\alpha_{0}+\alpha_{1} C F O_{t-1}+\alpha_{2} C F O_{t}+\alpha_{3} C F O_{t+1}+\varepsilon_{t}
$$

Where: 
$\Delta W C_{t}=$ change in working capital, calculated as: change in accounts payable + change in inventory- change in taxes payable + change in other assets (net);

$C F O=$ cash flow from operations;

Following McNichols (2002) and Francis et al. (2005), I also include the current year change in sales $(\triangle R E V)$ and the current year level of property, plant and equipment (PPE) as additional controls variables in Dechow and Dichev (2002)'s model (Modified DD Model hereinafter).

$$
\Delta W C_{t}=\alpha_{0}+\alpha_{1} C F O_{t-1}+\alpha_{2} C F O_{t}+\alpha_{3} C F O_{t+1}+\Delta R E V_{t}+P P E_{t}+\varepsilon_{t}
$$

Following Francis et al. (2005), I estimate both equation (3) and equation (4) cross-sectionally by year and by the two-digic SIC code. The absolute value of firmspecific residuals $\varepsilon_{\mathrm{t}}$ in equation (3) denoted as $A B S_{-} D D$ and in equation (4) as $A B S \_M D D$, which are the third and fourth measures for accrual quality used in this study.

My third set of accruals quality measures are based on the standard deviation of firm-and year-specific accrual estimation errors derived from equations (3) and (4). Smaller (larger) standard deviations of accrual estimation errors are relatively better (poorer) quality of accruals. I derive accruals quality measures by calculating standard deviations of firm-and year-specific residuals during the four years before and after the implementation of FIN 46. The fifth and sixth measures are respectively based on original model in equation (3) denoted as $S T D \_D D$ and on the modified model in equation (4) denoted as $S T D \_M D D$. 


\section{Empirical Models for Hypotheses Testing}

To test H1, I use a sample including both FIN 46 firms (firms affected by FIN 46) and No-Impact firms (firms reporting no material impact from the standard). I use following model that specifies accruals quality $(A Q)$ as a function of fundamental firm characteristics along with indicator variables for firms affected by FIN 46 and for the year of implementation of FIN 46, and interactions between them:

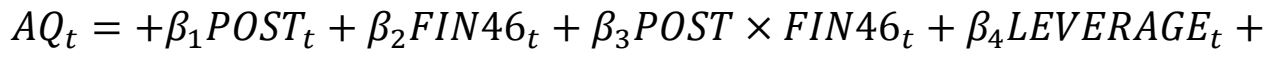

$$
\begin{aligned}
& \beta_{5} \text { GROWTH }_{t}+\beta_{6} \mathrm{SIZE}_{t}+\beta_{7} \text { ROA }_{t}+\beta_{8} O C F_{t}+\beta_{9} O C F 2_{t}+ \\
& \beta_{10} L O G_{-} C Y C L E_{t}+\varepsilon_{t}
\end{aligned}
$$

Where:

$A Q_{t}=$ six accrual quality measures as described above;

FIN46 $=1$ for firms affected by FIN 46, 0 otherwise;

LEVERAGE $E_{t}=$ book value of total debt divided by book value of total assets;

$G R O W T H_{t}=$ change in sales from year $\mathrm{t}-1$ to year $\mathrm{t}$ scaled by beginning total assets;

$R O A_{t}=$ return on assets;

$L O G_{-} C Y C L E_{t}=$ logarithm of the length of operating cycle;

$O C F_{t}=$ operating cash flow scaled by beginning total assets.

$O C F 2 t=$ the square of $O C F$.

POST=indicator variable for the post-adoption period of FIN 46

The variable of interest is the interaction variable POST $\times$ FIN46. The coefficient for the interaction term $\left(\beta_{3}\right)$ indicates whether the accrual quality changed for firms affected by 
FIN 46 during the post implementation period relative to firms reporting no material impact from the standard. A significant positive (negative) coefficient suggests that firms affected by FIN 46 are associated with poorer (better) quality of accruals during the postimplementation period compared firms not affected by FIN 46.

To test H2, I divide FIN 46 firms into two groups: firms consolidating VIEs (FIN46_CON) and firms keeping VIEs off the books (FIN46_OFF) following the approach used in Callahan et al. (2012), and test the change in accrual quality between these two groups. The sample includes all the three groups of firms.

$$
\begin{aligned}
& A Q_{t}=\beta_{0}+\beta_{1} \text { POST }_{t}+\delta_{1} \text { FIN46_CON }_{t}+\delta_{2} \text { FIN46_OFF } F_{t}+\delta_{3} \text { POST } \times \\
& \text { FIN46_CON }+\delta_{4} \text { POST } \times \text { FIN46_OFF } F_{t}+\beta_{4} L E V E R A G E_{t}+\beta_{5} G R O W T H_{t}+ \\
& \beta_{6} S I Z E_{t}+\beta_{7} R O A_{t}+\beta_{8} O C F_{t}+\beta_{9} O C F 2_{t}+\beta_{10} L O G_{-} C Y C L E_{t}+\varepsilon_{\mathrm{t}}
\end{aligned}
$$

The variable of interest is $P O S T^{*} F I N 46 \_C O N_{t}, \delta_{3}$ indicates the direction and magnitude of effects on accrual quality for firms consolidating VIEs relative to firms keeping VIEs off books during the post FIN 46 period.

For the tests of $A B S \_D D, A B S \_M D D, S T D \_D D$ and $S T D \_M D D, O C F$ and $O C F 2$ are not used as control variables since these measures are estimated from the regressions of working capital on cash flows.

\section{DATA AND SAMPLE}

Empirical analyses in this study are mainly conducted on a sample formed by manually identifying firms that are affected by FIN 46 and that disclose no material impact from FIN 46 in 10-K or 10-Q filings. To identify those firms I follow the 
approach used by Callahan et al. (2012). To test hypotheses I form three groups with sample firms depending on the effects of FIN 46 on those firms.

\section{Group 1: Consolidation Group (On-Book Group)}

I used 10-K wizard to identify a sample of firms that consolidated their variable interest entities (VIEs) in 2003 by searching 10-K and 10-Q forms reported in 2004. To ensure the accuracy of the search, I used different combinations of keywords that including the actual action of "consolidation" by the adoption of FIN 46, instead of the wording only describing the standard, like "have consolidated", "has consolidated", "we consolidated". 4 Some firms used passive voice, so I also used "was consolidated" and "were consolidated". In addition, some firms use "the company" to describe themselves so I also searched by "the company consolidated". These searching process identify 260 unique firms.

\section{Group 2: Off-Book Group}

I identify a sample of firms that keep their VIEs off the books. Some firms with VIEs try to avoid consolidation by terminating, restructuring, divesting or disposing the VIEs, therefore I searched 10-K and 10-Q forms using these four keywords combined with FIN 46. 113 unique firms are found through this searching method.

\footnotetext{
${ }^{4}$ If only searching by "FIN 46 "and "consolidated", the results will include any companies that describe the standard, for example: "FIN 46 requires a variable interest entity to be consolidated by a company", not the companies that actually did the consolidation.

${ }^{5}$ This keyword will also return results including "the company's consolidated", like "the company's consolidated financial statements". Therefore, I refined the keywords as "(FIN p/3 46 p/50 the company consolidated) AND NOT (FIN p/3 $46 \mathrm{p} / 50$ the company's consolidated)", then the results will exclude those searched by the latter group of key words.
} 
Feng et al. (2009) search likely VIEs in firms' exhibit 21 and consider entities

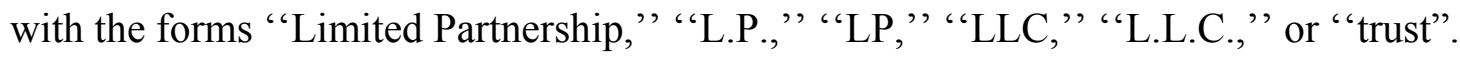
As they stated, this selection process will possibly exclude SPEs that don't have these organization forms or include SPEs that have been already consolidated in the financial statement. Since my research question focus on the impact of FIN 46, I find firms consolidating, terminating or restructuring VIEs (group 1 and group 2) by directly searching the words "VIE", "consolidated", "terminated", "restructured" in 10 forms. To ensure the accuracy of the test sample, I read each $10-\mathrm{K}$ form to find the description of such actions.

\section{Group 3: No Impact Group}

I find 1077 unique firms reporting "no impact" or "no material impact" from FIN 46 by searching in $10-\mathrm{K}$ forms. ${ }^{6}$

\section{Sample Derivation}

Table 1 Panel A provides the sample derivation for empirical analyses of abnormal accrual measures: abnormal total accruals $(A A)$, working capital accrual (AWCA), performance-matched abnormal total accrual (PM_AA) and working capital accruals $\left(P M \_A W C A\right)$. Searching using 10-K wizard, 260 firms consolidated VIEs through the adoption of FIN 46 (group 1). The sample is narrowed down to 184 firms after excluding firms with missing observations to estimate abnormal accruals. After deleting firms in financial industries (SIC 6000-6999), 144 firms are left. There are 2580 firm-year observations from 1988 - 2012 for group 1. Since my testing period is $1998-$ 2007, the final sample for group 1 includes 1225 firm-year observations.

\footnotetext{
${ }^{6}$ I excluded those firms overlapping with group 1 and group 2 from the initial searching results.
} 
Following the same sample deviation process, Group 2 and Group 3 have 592 and 5690 firm-year observations respectively from $1998-2007$.

Table 1 Panel B provides the sample derivation for the tests on accrual quality measured using the accrual estimation errors from the DD model. Using the similar filtering process, Group 1, 2, 3 have 509, 159 and 2690 firm-year observations respectively from 1998 - 2007. The pre-FIN 46 periods are defined as 1998-2001, the post-FIN 46 periods are defined as 2004-2007. The transition periods 2002-2003 are excluded from the analyses because accounting adjustments during this transition period may artificially affect the results. ${ }^{7}$

\section{EMPIRICAL FINDINGS}

\section{Descriptive Statistics}

Table 2 Panel A provides the descriptive statistics of the (performance-matched) abnormal total accruals, (performance-matched) working capital accruals and the control variables for the three groups of firms from 1998 - 2007. The mean absolute values of abnormal total accruals $\left(A B S \_A A\right)$ are 0.060 for firms consolidating VIEs (group 1), 0.060 for firms terminating or restructuring VIEs (group 2) and 0.116 for firms reporting no material impact from FIN 46 (group 3). The mean absolute value of abnormal working capital accruals $\left(A B S \_A W C A\right)$ are $0.057,0.051$ and 0.107 respectively for the three groups. The absolute values of performance-matched abnormal total accruals $\left(A B S \_P M A A\right)$ are $0.072,0.069$ and 0.121 respectively for the three groups. The absolute

\footnotetext{
${ }^{7}$ Initial development of FIN 46 started in early 2002 and adoption of the pronouncement could take several months over 2003. I expect full implementation of the pronouncement was completed by 2004 and financial statement for fiscal year 2004 onward would reflect the effect of FIN 46.

${ }^{8}$ In the regression analysis, I also require that same firms must be both in the pre- and post- FIN 46 periods.
} 
values of performance-matched working capital accruals $\left(A B S \_P M A W C A\right)$ are 0.062 , 0.055 and 0.109 respectively for the three groups.

The mean SIZE of group 1 and group 2 are 7.693 and 7.858 respectively, while the mean size of group 3 is 5.173. This is consistent with the fact that firms with SPEs (VIEs) are usually larger firms since they have better technical expertise to handle the complex financing arrangement (SEC 2005; Feng 2009). The mean LEVERAGE is 0.628 for group 1, 0.632 for group2, and 0.568 for group 3. This indicates that firms with SPEs (VIEs) usually have higher leverage than other firms. The mean $R O A$ of group 3 is 0.111, which is lower than group 1 (mean $R O A=0.005$ ) and group 2 (mean $R O A=0.014$ ). Table 2 Panel B reports the descriptive statistics for the accrual estimation errors from Dechow and Dichev (2002) model, the standard deviation for the accrual estimation errors developed by Dechow and Dichev (2002), and the control variables in the regression models. The mean absolute values of the accrual estimation errors $\left(A B S \_D D\right)$ are 0.043 for group $1,0.037$ for group 2 and 0.066 for group 3. $A B S \_M D D$ is the mean absolute value of the accrual estimation errors from the modified Dechow and Dichev (2002) model in McNichols (2002) and Francis et al. (2005). The mean $A B S \_M D D$ is 0.034 for group $1,0.031$ for group 2 and 0.058 for group 3. STD_DD is the standard deviation of the accrual estimation errors, which is the accrual quality measure in Dechow and Dichev (2002). STD_DD is 0.046 for group 1, 0.043 for group 2 and 0.078 for group 3. There is less variation in accrual estimation errors for firms with SPEs than those without SPEs. STD_MDD is the accrual quality measure used in McNichols (2002) and Francis et al. (2005). Group 1 has mean STD_MDD at 0.032, while group 2 has 0.037 
and group 3 has 0.065 . The descriptive statistics of the control variables are similar to those in Table 1 Panel A.

\section{Multiple Regression Analyses}

\section{Accruals Quality: Firms affected by FIN 46 versus No Impact Firms}

To test hypothesis 1 (H1) I estimate equation (3) by using three sets of proxies for accruals quality as dependent variables: (a) absolute value of performance matched abnormal total accruals - $A B S \_P M A A$, and performance matched abnormal working capital accruals - $A B S \_P M A W C A$, (b) absolute value of accruals estimations errors using the DD model- $-A B S \_D D$ and absolute value of accruals estimations errors from the Modified DD model $-A B S \_M D D$, and (c) accruals quality measures using the DD model and Modified DD Model.

\section{Absolute Value Performance-Matched Abnormal Accruals}

Table 3 provides the regression results of equation (3) using the performancematched abnormal total accruals $\left(A B S \_P M A A\right)$ and the performance-matched abnormal working capital accruals $\left(A B S \_P M A W C A\right)$. All three groups of firms in the sample are used in estimating regressions, where the test sample consists of observations in Groups 1 and 2, and control sample with observations in Group 3. For both measures, the coefficients of the variable of interest POST $^{*} F I N 46$ are not significant. ${ }^{9}$

The coefficients for the control variables are consistent with prior studies. The coefficient of $L E V E R A G E$ is positive and significant $(\mathrm{p}<0.0001)$, indicating that firms with high leverage are more likely to have higher abnormal accruals. The coefficient for

\footnotetext{
${ }^{9}$ I also use the non-performance matched measure, absolute value of abnormal total accruals $\left(A B S \_A A\right)$ and absolute value of abnormal working capital accruals $\left(A B S \_A W C A\right)$, for additional tests, the results are not significant either.
} 
SGROWTH is positive and significant $(\mathrm{p}<0.0001)$ since sales growth is associated with higher abnormal accruals. The coefficient for SIZE is negative and significant $(\mathrm{p}<0.0001)$ since larger firms tend to have lower abnormal accruals. $L O G \_C Y C L E$ is positively associated with abnormal accruals, suggesting firms with longer operating cycle have higher abnormal accruals. The adjusted $\mathrm{R}^{2}$ is $27.50 \%$ for the $A B S \_P M A A$ test and $29.28 \%$ for the $A B S \_P M A W C A$ test. The adjusted $\mathrm{R}^{2}$ is higher for the $A B S_{-} P M A W C A$ regression. Prior research argues that firms have more discretion on managing working capital accruals compared to long term accruals.

\section{Absolute Value of Accrual Estimation Errors}

I then estimate equation (3) by using absolute values of accruals estimation errors ( $A B S \_D D$ and $A B S \_M D D$ respectively) from the DD model and the Modified DD model. Results are presented in Table 4. Adjusted $\mathrm{R}^{2}$ for $A B S_{-} D D$ and $A B S_{-} M D D$ are 18 percent and 22 percent, respectively. Coefficients of all control variables are consistent with those reported in previous table with abnormal accruals measures. $R O A$ is negatively associated with $A B S_{-} D D$ and $A B S_{-} M D D$, consistent with firms with better performance have higher accrual quality. The correlation is negative since the accrual quality is taken the absolute value, and lower value of the dependent variable indicates higher accrual quality. The coefficients of the variable of interest POST*FIN46 are not significant for $A B S \_D D$ but positive and significant for $A B S \_M D D(\mathrm{p}=0.032)$, suggesting that firms impacted by FIN 46 are likely to experience lower level of accruals quality measured by $A B S \_M D D$ compared to firms reporting no impact from the standard during the post implementation periods. 


\section{Standard Deviation of Accruals Estimation Errors}

I then use a third set of proxies for accruals quality, which are measured as the standard deviation of firm-specific accruals estimation errors $\left(S T D \_D D\right.$ and $S T D \_M D D$ respectively) from the DD model and Modified DD model. Standard deviations are estimated by using firm specific accrual estimation errors from cross sectional regressions during four years pre-and post-FIN46 periods. Results are presented in Table 5.

The adjusted $\mathrm{R}^{2}$ is $22.23 \%$ for the regression with $S T D \_D D$ and $24.92 \%$ for STD_MDD as the dependent variable. An increase in adjusted R-square for the measure from the augmented model is consistent with the assertion made by Francis et al. (2005) that the modified model lead to "a better -specified stream of residuals". Control variables are consistent with prior studies. Sales growth and operating cycle are positively associated with the accruals quality suggesting that the higher the sales growth or the larger the operating cycle, it is more difficult to estimate accruals. On the other hand, the coefficients of size are significantly negative suggesting that larger firms have more stable operations and less difficult to estimate accruals. The variable of interest POST *FIN46 are consistently significant in both estimations $(\mathrm{p}=0.035, \mathrm{p}=0.075$ respectively). These findings are consistent with results with absolute value of accruals estimation errors $\left(A B S_{-} M D D\right)$ reported in the previous table.

Overall, by using three different set of proxies for accruals quality I find mixed results. For accrual quality measured by $A B S \_M D D, S T D_{-} D D$ and $S T D \_M D D$, the results are significant and consistent, suggesting that firms affected by FIN 46 are more 
likely to experience poorer accruals quality during the post-implementation period compared to firms that disclose no material impact by FIN 46 .

\section{Accruals Quality: Firms Consolidated versus Restructured or Terminated}

The second hypothesis predicts differential effects of FIN 46 on accruals quality for firms consolidating their VIEs on the book (group1) versus firms either restructure VIEs to keep them off the book or terminate VIEs (group 2). Similar to the analyses reported for hypothesis 1, I conduct three sets of analyses by using absolute value of abnormal accruals and accruals estimation errors and standard deviation of accrual estimation errors as the dependent variables in equation (6)

\section{Absolute Value Performance-Matched Abnormal Accruals}

Table 6 provides the regression results of equation (6) using the absolute value performance-matched abnormal total accruals $\left(A B S_{-} P M A A\right)$ and the performancematched abnormal working capital accruals (ABS_PMAWCA). All three groups of firms in the sample are used in estimating regressions, where the test sample consists of observations in Groups 1 and 2, and control sample with observations in Group 3. The variable of interests are interaction terms POST*FIN46_CON and POST*FIN46_OFF,

which reflect differential effects of FIN 46 implementation conditional upon whether the affected firm has consolidated VIEs with their financial statements, or restructured or terminated VIE to avoid consolidation.

Coefficients of all control variables are consistent with that reported in table 3.

The variable of interests, both interaction terms POST*FIN46_CON and POST*FIN46_OFF, are not significant. 


\section{Accruals Estimation Errors}

I then use two sets of accruals quality metrics based on accruals estimation errors. The first set is absolute values of accrual estimation errors from the DD model and Modified DD model and the second set is standard deviations of accrual estimation errors. Table 7 provides the regression results using absolute values of accrual estimation errors. Consistent with absolute value of accruals results, the variable of interests are the interaction terms POST*FIN46_CON and POST*FIN46_OFF. For the ABS_MDD test, the coefficient of POST*FIN46_CON is positive and significant while the coefficient of POST*FIN46_OFF is not significant. This is consistent with the hypothesis that firms consolidating VIEs experience decrease in accrual quality (measured by $A B S \_M D D$ ) compared to firms avoiding consolidation. All other control variables are consistent with previous analyses.

Table 8 reports regression results of equation (6) where dependent variables are standard deviation of accrual estimation errors. Coefficients of POST*FIN46_CON are positive and significant in both regressions ( $\mathrm{p}=0.026$ and $\mathrm{p}=0.051$ respectively). The other interaction term is not significant. This is consistent with the hypothesis that firms consolidating VIEs experience decrease in accrual quality (measured by $S T D \_D D$ and STD_MDD) compared to firms avoiding consolidation.

\section{Analyses with Matched Pair Control Groups}

\section{FIN 46 Firms (Group 1\&2) vs. Matched Pairs}

In the previous sections, all empirical analyses use Group 3 as the control group that comprises firms disclosing no material impact from FIN 46. Table 2 shows observations in this group are significantly smaller and poor performers compared to 
firms in Group 1 and 2. So I control for firms characteristics in all my preceding multivariate regressions. In this section, I provide complementary analyses by using a matched-pair sample as control group. I form this control sample by selecting matched observation for each FIN 46 firm-year observation. Specifically, for each firm-year observation in the test sample, I chose a matched pair from all the firms not affected by FIN 46, in the same year and same industry, requiring the closest ROA by restricting size difference less than $1 .^{10}$

Table 9 panel A provides the univariate test for the difference between the accrual quality measures in the pre- and post- FIN 46 periods for the FIN 46 firms and the matched pairs. For $A B S \_D D$, FIN 46 firms experience no significant change while the matched pairs experience significant decrease. There are same changes with regard to $A B S_{-} M D D$. For $S T D \_D D$, there is no significant change between the pre- and post- FIN 46 periods for both groups. For $S T D \_M D D$, FIN 46 firms experience significant increase while the matched pairs experience no significant change. For $A B S \_A A, A B S \_A W C A$, $A B S \_P M A A$ and $A B S \_P M A W C A$, the change between the pre- and post- FIN 46 periods is similar for both groups.

The regression results are shown in Table 9 panel B. By using the matched pairs as the new control group, only $A B S \_M D D$ and $S T D \_M D D$ are significant different between the test and control sample. The coefficient of POST*FIN46 are positive and significant for both measures ( $\mathrm{p}=0.015$ and 0.029 respectively). This is consistent as the results in Table 4 and table 5. The significant differences in $A B S \_M D D$ and STD_MDD

\footnotetext{
${ }^{10}$ The duplicate matches are deleted.
} 
between the test and different control samples shed some light to explain the accrual quality changes for the FIN 46 firms.

\section{Group 1 vs. Matched Pairs and Group 2 vs. Matched Pairs}

To see the differences between the changes in accrual quality for firms consolidating VIEs (group 1) and firms terminating or restructuring VIEs (group 2), I selected a matched pair for group 1 and group 2 respectively. There is no significant difference between group 2 and its matched pairs after FIN 46 (untabulated). However, the accrual quality measured by $A B S \_M D D$ and $S T D \_M D D$ for group 1 is decreased after the implementation of FIN 46 compared to the matched pairs, as shown in Table 10. The coefficients of POST $^{*} F I N 46$ are positive and significant $(\mathrm{p}=0.010$ and 0.027 respectively). This indicate that firms consolidating VIEs experiences worse accrual quality measured by $A B S \_M D D$ and $S T D \_M D D$ compared to the matched pairs.

\section{Group 1 vs. Group 2}

When using group 1 as the test sample and group 2 as the control sample, I find the accrual quality measured by $A B S_{-} M D D, S T D_{-} D D$ and $S T D_{-} M D D$ for group 1 decreases in the post-FIN 46 periods compared to group 2 (shown in Table 11), suggesting that the consolidation process affects accrual quality more than the termination or restructuring. The results are consistent with those in Table 7 and Table 8 , and provide further evidence suggesting that group 1 experiences decrease in accruals quality measured by $A B S \_M D D, S T D \_D D$ and $S T D \_M D D$ compared to group 2 .

\section{Analyses with Signed Abnormal Accrual Measures}

Although the decrease in accrual quality cannot be totally attributed to accrualbased earnings management (Dechow and Dichev 2002), it is worthwhile to examine 
whether the accruals management can explain the decrease in accrual quality in this study. I conduct tests for $\mathrm{H} 1$ and $\mathrm{H} 2$ using signed abnormal accrual measures and find no significant change for FIN 46 firms overall. However, among the FIN 46 firms, I find that

firms consolidating VIEs (group 1) experience increase in all the four abnormal accrual measures $(A A, A W C A, P M A A, P M A W C A)$ in the post-FIN 46 period compared to firms restructuring or terminating VIEs (group 2). As shown in Table 12 and Table 13, the coefficients of $P O S T^{*} F I N 46 \_C O N$ are positive and significant for all the four measures. This provides partial explanation for the results for H2. Firms consolidating VIEs experiences bigger loss after the consolidation, they may have more pressure and incentive to conduct income-increasing earnings management using accruals.

\section{Robustness Tests}

I also do the tests by excluding 2004 as transitory period and the results still hold. To be consistent with some previous studies, I also control for $O C F$ and $O C F 2$ for the $A B S \_D D, A B S \_M D D, S T D \_D D, S T D \_M D D$ tests, the results are consistent (untabulated).

\section{SUMMARY}

This study examines how the accruals quality for firms affected by FIN 46 changes in the post-implementation periods. I compare accruals quality of firms affected by FIN 46 before and after the implementation of this accounting pronouncement by using a number of proxies for accruals quality. I find that compared to firms reporting no material impact from FIN 46, firms adopting the new accounting guidance relating to SPEs experience lower quality of accruals, measured by the accrual estimation errors 
from the modified DD 2002 model $\left(A B S_{-} M D D\right)$ and the standard deviation of the residuals from the DD 2002 model and its modified version (STD_DD and $S T D \_M D D$ ). I then use matched pair control sample replacing "no material impact" group from the estimation and I find the accrual quality measured by $A B S_{-} M D D$ and $S T D \_M D D$ have consistent results as before.

When it comes to the differences between the two subgroups in the FIN 46 firms (firms consolidating VIEs and firms terminating or restructuring VIEs), the results consistently show that the accrual quality measured by $A B S \_M D D$ and $S T D \_M D D$ for firms consolidating VIEs (group 1) are consistently worsened compared to group 2, no matter which control sample is used. The differential change in accrual quality between the two groups can be partially attributed to the facts that group 1 have pressure to manage earnings when the consolidation bring negative effect on earnings. The empirical results of income-increasing earnings management confirm this point.

These results help us understand the changes in accrual quality for firms impacted by FIN 46. Although the consolidation process and improved disclosure may constrain earnings management through previously off-balance sheet SPEs, firms may resort to other methods that bypass VIEs to manipulate earnings, thus worsen the accrual quality in the post-FIN 46 periods.

My study is subject to limitations. First, the small sample size of the test sample affects the estimation accuracy of the regression analysis; second, the types of VIEs are not separated in the analysis. It is possible that the results are driven by certain category of VIEs, but not all. 


\section{CHAPTER IV: IMPLICATIONS OF FIN 46 FOR INVESTMENT EFFICIENCY}

\section{MOTIVATION}

The first part of this dissertation research shows how the financial reporting quality changes with the implementation of the Financial Accounting Standards Board (FASB) issued Interpretation No. 46 (FIN 46 hereinafter), Consolidation of Variable Interest Entities- An Interpretation of ARB No. 51. I now focus on effects of FIN 46 on investment decisions made by affected firms. More specifically I examine the investment efficiency of affected firms during the pre- and post-FIN46 periods. This particular question is important because of the following reasons. First, the implementation of FIN 46 may have significant influence on financial reporting quality that includes quality of reported accounting numbers (i.e., accruals quality) and quality of disclosures. Second, FIN 46 likely to reduce affected firms' financial flexibility by eliminating the opportunity to use certain off-balance sheet items and thus create financial constraints. Prior studies show that investment efficiency is associated with quality of financial reporting as well as with financial constraints (e.g., Biddle and Hilary 2006, Biddle et al. 2009 etc.). Thus, FIN 46 provides a unique setting to test how the implementation of the accounting guidance affects investment efficiency.

Since the stated objectives of FIN 46 are to improve the transparency of financial reporting of firms with VIEs and to reduce the information asymmetry between firms and investors, the investment efficiency of firms affected by FIN 46 is expected to improve after the adoption of the standard. However, as the empirical findings of the first part of the dissertation suggest, the accruals quality of firms affected by FIN 46 becomes poorer 
after the adoption of FIN 46 compared to firms not affected by the standard. Prior studies show that there is a positive relation between accruals quality and investment efficiency (e.g., Biddle and Hilary 2006). From such perspective, the investment efficiency of firms affected by FIN 46 may decrease during the post-implementation periods since the quality of accruals for affected firms deteriorates. On the other hand, provisions in FIN

46 mandate enhanced disclosures relating to VIEs, which may help improve information flow relating off-balance sheet activities through special purpose entities, which can mitigate information asymmetry and thus, may have positive effects on investment decisions. Therefore, it is worthwhile to investigate how FIN 46 affects investment efficiency of firms affected by the standard.

\section{LITERATURE REVIEW}

Firms' investment is influenced by the marginal q and marginal cost of capital increase (Yoshikawa 1980; Hayashi 1982). Investment is efficient when firms choose projects that have positive net present value and when firms continue to invest efficiently until the marginal rate of return to investment become zero (Biddle et al. 2009). Prior research suggests that information asymmetries between firms' management and investors can influence investment efficiency by creating economic frictions such as moral hazard and adverse selection, which can each lead to inefficient investment (Stein 2003). The Moral hazard models suggest managers could choose to invest in projects that do not necessarily maximize the value of the firm when their incentives are incongruent with those of the investors (Berle and Means 1932; Williamson 1974; Jensen and Meckling, 1976). Adverse selection occurs when managers have more information about the firm than investors, managers tend to act in favor of their own benefits (Myers and 
Majluf, 1984). The level of investment is also affected by the availability of financial resources. Financial-constrained firms are more likely to under-invest and financialunconstrained firms are more likely to over-invest (e.g., Jensen 1986; Myers 1997; Opler et al. 1999; Richardson 2006).

Prior studies have shown that accounting quality is associated with investment efficiency (e.g., Bushman and Smith 2001; Healy and Palepu 2001; Bens and Monahan 2004; Lambert et al. 2007; Beatty et al. 2008; McNichols and Stubben 2008; Francis and Martin 2010; Bushman et al. 2011). Higher financial reporting quality can reduce moral hazard and adverse selection, thus mitigate information asymmetry and increase investment efficiency (e.g., Leuz and Verrecchia 2000; Verrecchia 2001). Biddle and Hilary (2006) find higher accounting information quality enhances investment efficiency measured by investment-cash flow sensitivity, since the information asymmetry between managers and investors is reduced by higher-quality financial information. Biddle et al. (2009) provide further evidence that higher quality accounting information improves investment efficiency by reducing both over-investment and under-investment. Cheng et al. (2013) use a sample of firms disclosing internal control weakness (ICW) and find that these firms experience reduced under- (over-) investment after the disclosing of ICWs. The information problem signaled by ICWs should be fixed after the disclosure, thus the financial reporting quality is enhanced in the post-disclosure period.

The relation of financial accounting quality and investment efficiency is also investigated in international context. By focusing a sample of Spanish firms, Gomariz et al. (2014) investigate how investment efficiency is affected by financial reporting quality and debt maturity. They find over-investment is reduced by higher financial reporting 
quality, and find both over- and under- investment can be reduced by lower debt maturity. Chen et al. (2011) focus private firms in emerging market to investigate the relation between financial reporting quality and investment efficiency. They find a positive relation between financial reporting quality and investment efficiency, and the relation is affected by bank financing and tax saving incentives. Shroff et al. (2014) examine how the investment decisions of multinational corporations (MNCs) are affected by the information environment of the country-industry where the foreign subsidiary is located. They find the external information environment reduces the information frictions for the MNCs. In the country-industry where the information environment is more transparent, the investment decisions of the foreign subsidiaries are more related to the growth opportunities.

Some other factors also affect investment efficiency. The gap between the executive compensation leverage ratio and the firm leverage ratio is associated with managers' likelihood of either under-investment or over-investment, thus affect investment efficiency (Eisdorfer et al. 2013). Beatty et al. (2013) examine how the investment of the peer companies of the fraud firms is affected the fraud committed. They find peer companies increase investment during the fraud period, and increase investment in "industries with higher investor sentiment, lower cost of capital and higher private benefit of control".

Investment efficiency is affected by financial accounting standards, which usually improve the disclosure. Biddle et al. (2011) find the mandatory adoption of IFRS helps increase investment efficiency since IFRS increases the disclosure and comparability of financial information, thus mitigate the information asymmetry. They measure 
investment efficiency not only using the investment cash-flow sensitivity, but value enhancing-risk taking.

An extensively used measure for investment efficiency is investment - cash flow sensitivity. Fazzari et al. (1988) estimate investment - cash flow sensitivity by regressing investment on cash flows by controlling for Tobin's Q, which is proxied by market-tobook ratio. They find that financially constrained firms have investment that is more sensitive to cash flows than unconstrained firms. Kaplan and Zingales (1997) find opposite results by using different method to partition the constrained and unconstrained firms. These conflicted results are reconciled by Moyen (2004), who find consistent results for either study by using different models.

\section{HYPOTHESIS DEVELOPMENT}

Before FIN 46, SPEs are kept off the financial statements, causing information asymmetry between company's internal management and external investors. Information asymmetry between managers and investors creates economic frictions resulting in inefficient investment decisions. FIN 46 improves disclosure and likely to reduce information asymmetry, which may mitigate problems of moral hazard and adverse selection. Specifically, firms with VIEs affected by FIN 46 respond to the standard by consolidating, terminating, or restructuring their VIEs. Irrespective of responses by firms whether consolidating or restructuring VIEs, affected firms need to disclose detailed information about the nature, type and magnitude of transactions carried by those subsidiaries. Since more information is made available to investors after the implementation of FIN 46 by the affected firms, the information asymmetry between 
managers and investors likely to reduce, thus the moral hazard caused by information asymmetry is mitigated. The decrease in the economic frictions due to the improvement in financial information disclosures is expected to result in increased investment efficiency.

However, as it is shown by the empirical results in the first part of the dissertation, the accrual quality of firms affected by FIN 46 decreases in the post-FIN 46 periods compared to firms not affected by the standards. The lower quality of accruals after the implementation of FIN 46 is likely to have an adverse effects on the quality of investment decisions made by the affected firms.

Thus the implementation of FIN 46 may have either positive or adverse effects on investment efficiency of firms depending upon which effect dominates. Considering the two perspectives above, I formulate a non-directional hypothesis, stated as follows: H3: $\quad$ After FIN 46, firms with VIEs experience a change in investment efficiency compared to firms not affected by the standard.

Among the firms having VIEs and affected by FIN 46, some firms consolidated their VIEs while others avoid consolidation by restructuring or terminating the VIEs. Callahan et al. (2012) find that there is deferential effect on cost of capital between these two groups of firms. Firms consolidating their VIEs may have adverse effects on their leverage and profitability ratios, which create pressures on firms' ability and flexibility in financing options and thus influence investment decisions. On the other hand, firms restructuring or terminating VIEs (group 2) have the flexibility or ability to avoid consolidation. Different features for the two groups can be reflected in the consequences from the empirical regularities relating to FIN 46. Furthermore, Bonsall IV and Bozanic 
(2012) find that there is less information asymmetry related to consolidated VIEs than unconsolidated VIEs. Since reduced information asymmetry is associated with enhanced investment efficiency, firms consolidating VIEs are expected to experience greater improvement in investment efficiency than firms bypassing the consolidation by restructuring or terminating VIEs.

However, the first part of the dissertation shows that firms consolidating VIEs experience decreased accruals quality after the adoption of FIN 46 compared with firms keeping VIEs off the financial statements by terminating or restructuring these entities. Considering the opposite perspectives, the fourth hypothesis is stated as follows:

H4: After FIN 46, firms consolidating VIEs experience a change in investment efficiency compared to firms that terminate or restructure VIEs to avoid consolidation.

\section{RESEARCH DESIGN}

\section{Investment Efficiency Measures}

I use two complementary measures of investment efficiency, which are used in the extant Accounting and Finance literature.

\section{Cash Flow Sensitivity of Investment (CFSI)}

I use cash flow sensitivity of investment $(C F S I)$ as a proxy for investment efficiency following Biddle and Hilary (2006). Underlying rationale of this measure as a proxy for investment efficiency is that the current level of investments should not be associated with the cash flows generated by the operation. In the absence of any economic frictions that trigger capital rationing or investing beyond optimum level, 
investment decisions should be based on the expected rate of marginal returns from the investment projects, thus any association between investments and cash flows after controlling for growth opportunities is a reflection of inefficient investment. This measure is used extensively in prior literature (e.g., Fazzari et al. 1988; Hoshi et al. 1991).

$$
\text { Investment } \mathrm{i}_{\mathrm{i}, \mathrm{t}}=\beta_{0}+\beta_{1} O C F_{t}+\beta_{2} M B_{\mathrm{i}, \mathrm{t}}+\xi_{\mathrm{i}, \mathrm{t}}
$$

Investment is the sum of research and development expenditure, capital expenditure, and acquisition expenditure less cash receipts from sale of property, plant, and equipment scaled by lagged total assets. $O C F$ is operating cash flow scaled by lagged total assets. $M B$ is market value of equity divided by total assets, which is a proxy for Tobin's Q. $\beta_{1}$ is the measure of investment-cash flow sensitivity.

\section{Deviation from Expected Investment}

Another measure of investment efficiency is the deviation from expected investment used by Biddle et al. (2009). Investment efficiency is measured based on the likelihood that a firm deviates from the expected investment level. They use a firmspecific model of investment as a function of growth opportunities (as measured by sales growth) and use the residuals as a firm-specific proxy for deviations from expected investment. Considering the relation between investment and sales growth is related to the increase or decrease of the sales, Chen et al. (2011) also include an indicator variable of negative sales growth and its interaction with sales growth in the model to estimate the deviation from expected investment. I used the absolute value of the residuals of the following model (INVEFF) as used in Chen et al. (2011) for my second measure of investment efficiency. 
Investment $_{\mathrm{i}, \mathrm{t}}=\lambda_{0}+\lambda_{1} N E G_{i, t-1}+\lambda_{2}$ SalesGrowth $_{\mathrm{i}, \mathrm{t}-1}+\lambda_{3} N E G^{*}$ SalesGrowth $_{\mathrm{i},-1-1}+\xi_{\mathrm{i}, \mathrm{t}}$

Investment $_{t}$ is the sum of research and development expenditure, capital expenditure, and acquisition expenditure less cash receipts from sale of property, plant, and equipment scaled by lagged total assets. Sales Growth $_{t-1}$ is the percentage change in sales in year $t-1 . N E G_{t-1}$ is an indicator variable for negative sales growth in year $\mathrm{t}-1$. Equation (8) is estimated for each industry-year based on the Fama and French 48industry classification for all industries with at least 20 observations in a given year from a sample of all observations in the Compustat database with available data. The absolute value of the residuals (INVEFF1) is the investment efficiency measure.

I also use two additional measures of investment efficiency, as used in Chen et al. (2011). The first one is estimated by adding lagged investment in Equation (8) (as shown in equation (9). The second one is estimated by replacing revenue growth with asset growth in Equation (8) (as shown in equation (10)) as the proxy for investment opportunities (first used by McNichols and Stubben, 2008).

$$
\begin{aligned}
\text { Investment }_{i, t}= & \lambda_{0}+\lambda_{1} \text { NEG }_{t-1}+\lambda_{2} \text { SalesGrowt }_{i, t-1}+\lambda_{3} N E G^{*} \text { SalesGrowth }_{i, t-1} \\
& +\lambda_{4} \text { Investment }_{i, t-1}+\xi_{i, t+1} \\
\text { Investment }_{i, t}= & \lambda_{0}+\lambda_{1} N E G_{t-1}+\lambda_{2} \text { AssetGrowth }_{i, t-1}+\lambda_{3} N E G^{*} \text { AssetGrowth }_{i, t-1} \\
& +\xi_{i, t}
\end{aligned}
$$

The absolute values of the residuals from these regressions are $I N V E F F_{2}$ and $I_{N V E F F}$ respectively.

\section{Regression Models for Testing Hypotheses}

To provide support for $\mathrm{H} 3$, I examine the change in cash flow sensitivity of investment for firms affected by FIN 46 and firms reporting no material impact by the 
standard. I extend equation (7) by adding two indicator variables and interacting those indicator variables with the cash flow variable in the following model:

$$
\begin{aligned}
& \text { Investment }_{i, t}=b+\eta_{1} P O S T+\eta_{2} \text { FIN } 46+b_{1} O C F_{i, t}+\eta_{3} \text { FIN46 }^{*} O C F_{i, t} \\
& +\eta_{3} \text { POST }^{*} O C F_{i, t}+\eta 3 P O S T^{*} \text { FIN }_{4} * O C F_{i, t}+b_{2} M B_{i, t} \\
& +b_{3} S_{i z e_{i, t}}+\varepsilon_{i, t,}
\end{aligned}
$$

The variables are as described in previous equations. The variable of interest is

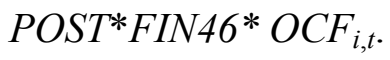

The absolute values of firm-specific residuals from Equation (8) and the two additional regressions described above are another set of investment efficiency measures (INVEFF1, INVEFF2, INVEFF3) that I use as dependent variables in the following model:

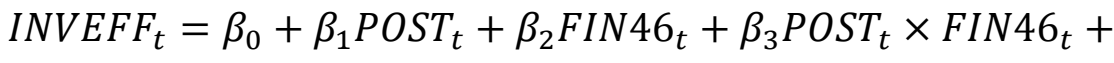

$$
\begin{aligned}
& \sum \gamma \text { Control }+\varepsilon_{t}
\end{aligned}
$$

The control variables in equation (12) include the following: SIZE, logarithm of lagged total assets; Leverage, measured as total liability divided by total assets; ROA, income before extraordinary items divided by lagged total assets; $M B$, the market value of equity divided by total assets; Tangibility, measured as property, plant and equipment divided by total assets; $K$-structure, measured as long-term debt divided by the sum of long-term debt and the market value of equity; CFOsale, operating cash flow divided by sales; Slack is cash divided by property, plant and equipment; Dividend is an indicator variable for firm paid a dividend; OPCycle, operating cycle measured as the sum of 365 divided by inventory turnover and 365 divided by receivable turnover. 


\section{Alternative Tests}

I also did a set of alternative tests by combining the estimation of deviation from expected investment and the regression in the same equation.

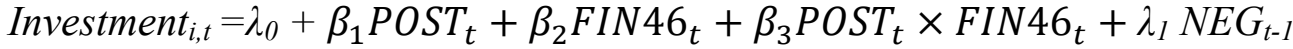

$$
\begin{aligned}
& +\lambda_{2} \text { SalesGrowth }_{i, t-1}+\lambda_{3} N E G^{*} \text { SalesGrowth }_{i, t-1}+\sum \gamma \text { Control } \xi_{i, t}
\end{aligned}
$$

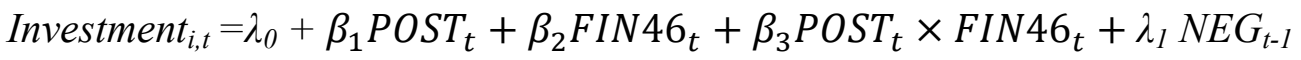

$$
\begin{aligned}
& +\lambda_{2} \text { Sales Growth }_{i, t-1}+\lambda_{3} N E G^{*} \text { SalesGrowth }_{i, t}+\lambda_{4} \text { Investment }_{i, t-1} \\
& +\Sigma \gamma \text { Control }+\xi_{i, t}
\end{aligned}
$$

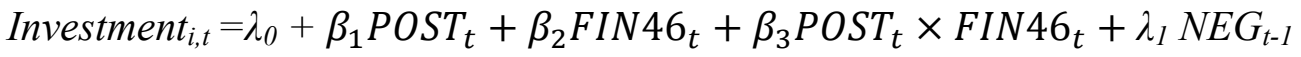

$$
\begin{aligned}
& +\lambda_{2} \text { AssetGrowth }_{i, t-1}+\lambda_{3} N E G^{*} \text { AssetGrowth }_{i, t-1}+\sum \gamma \text { Control }+\xi_{i, t}
\end{aligned}
$$

To test H4, I use group 2 as the control sample for group 1 to directly test the

difference between them. I also use the same models above by adding indicator variables $O N B O O K$ for firms consolidating VIEs and $O F F B O O K$ for firms restructuring or terminating VIEs and their interaction with $P O S T$ respectively $\left(P O S T^{*} O N B O O K\right.$ and POST*OFFBOOK).

\section{DATA AND SAMPLE}

Empirical analyses in this study are mainly conducted on a sample formed by manually identifying firms that are affected by FIN 46 and that disclose no material impact from FIN 46 in 10-K or 10-Q filings. To identify those firms I follow the 
approach used by Callahan et al. (2012). To test hypotheses, I form three groups with sample firms depending on the effects of FIN 46 on those firms.

\section{Group 1: Consolidation Group (On-Book Group)}

I used 10-K wizard to identify a sample of firms that consolidated their variable interest entities (VIEs) in 2003 by searching 10-K and 10-Q forms reported in 2004. To ensure the accuracy of the search, I used different combinations of key words that including the actual action of "consolidation" by the adoption of FIN 46, instead of the wording only describing the standard, like "have consolidated", "has consolidated", "we consolidated". Some firms used passive voice, so I also used "was consolidated" and "were consolidated". In addition, some firms use "the company" to describe themselves so I also searched by "the company consolidated". These searching methods returned 260 unique firms.

\section{Group 2: Off-Book Group}

I identified a sample of firms which keep their VIEs off books. Some firms with VIEs try to avoid consolidation by terminating, restructuring, divesting or disposing the VIEs, therefore I searched $10-\mathrm{K}$ and $10-\mathrm{Q}$ forms using these four key words combining with FIN 46. 113 unique firms are found through this searching method.

Feng et al. (2009) search likely VIEs in firms' exhibit 21 and consider entities

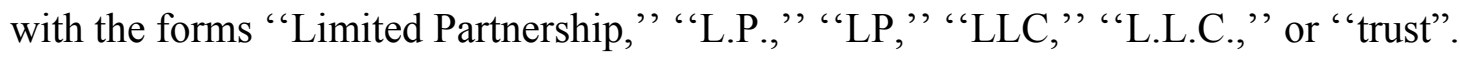
As they stated, this selection process will possibly exclude SPEs that don't have these organization forms or include SPEs that have been already consolidated in the financial statement. Since my research question focus on the impact of FIN 46, I find firms consolidating, terminating or restructuring VIEs (group 1 and group 2) by directly 
searching the words "VIE", "consolidated", "terminated", "restructured" in 10 forms. To ensure the accuracy of the test sample, I read each $10-\mathrm{K}$ form to find the description of such actions.

\section{Group 3: No Impact Group}

I found 1077 unique firms reporting "no impact" or "no material impact" from FIN 46 by searching in 10-K forms.

\section{Sample Derivation}

Table 14 provides the sample selection process. Through the searching process using $10-\mathrm{K}$ wizard and manually verifying $10-\mathrm{K}$ and 10-Q, I find 260 firms that have adopted FIN 46 and consolidated VIEs in their financial statements (group 1). After eliminating firms with missing value to estimate variables used in empirical analyses and deleting firms in financial industries (SIC 6000-6999), this group is left with 135 firms. There are 1791 firm-year observations from 1988 - 2012 for group 1 . Since my testing period is 1998 - 2007, the final sample for group 1 includes 784 firm-year observations.

Following the same sample deviation process, Group 2 and Group 3 have 361 and 4728 firm-year observations respectively from $1998-2007$.

The pre-FIN 46 periods are defined as 1998-2001, the post-FIN 46 periods are defined as 2004-2007. The transition periods 2002-2003 are excluded from the testing period.

\section{EMPIRICAL FINDINGS}

\section{Descriptive Statistics}


Table 15 presents the descriptive statistics for FIN 46 firms (group $1 \& 2$ ) and firms not impacted by FIN 46 (group 3) from 1998 to 2007. The mean of INVEFF1, the absolute value of the residual of Chen et al. 2011 model, is 0.116 for the FIN 46 firms and 0.193 for the no impact firms. The mean of INVEFF2, the absolute value of residuals from equation (9), is 0.099 and 0.156 respectively for the two groups. The mean of INVEFF 3 , the absolute value of residuals from equation (10), is 0.119 and 0.174 for the test sample and the control sample respectively. Firms in group 3 "no impact group" that is used as control sample in empirical analyses are characterized with relatively smaller in size, less profitable in terms of ROA and proportion of firms reporting losses, longer operating cycle and lower operating cash flows compared to firms in group 1 and 2, firms affected by FIN 46. Since firm characteristics of control group differ nontrivially from the test samples, I control for all firm characteristics in multiple regression models. In addition to controlling for the firm characteristics, I also use matched pair control sample to ensure the robustness of the results.

\section{Multiple Regression Analyses}

\section{Investment Efficiency: Firms affected by FIN 46 versus Firms not Materially Impacted}

\section{Investment Cash-Flow Sensitivity Tests}

I test investment-cash flow sensitivity of firms affected by FIN 46 by using equation (11) and estimating it with two sets of control groups-firms disclosing no material impact (group 3) and matched pair control sample. 


\section{Group 3 as Control Sample}

The regression results for the test of investment-cash flow sensitivity are presented in Table 16. Here test sample includes firms having VIEs affected by FIN 46 (group 1 and 2). The control sample includes firms reporting no (material) impact from FIN 46 (group 3). The coefficient for market-to-book (MB) ratio is positive and highly significant $(\mathrm{p}<.0001)$ suggesting the level of investment is increasing in the firm's growth opportunity. The coefficients for $O C F$ and interaction variable $F I N 46^{*} O C F$ are both negative and the coefficient for $P O S T^{*} O C F$ positive, which are all highly significant $(\mathrm{p}<.0001)$. These results suggest the investment-cash flow association is negative for the whole sample of firms either affected or disclosed no impact by FIN 46 and the investment-cash flow sensitivity increased significantly after the implementation FIN 46 for all firms.

The variable of interest is a three way interaction term $P O S T^{*} F I N 46^{*} O C F$, which tests the difference-in-differences for investment-cash flow sensitivity between pre-and post-implementation period comparing firms affected by FIN 46 versus firms reporting no material impact. The coefficient of $P O S T^{*} F I N 46^{*} O C F$ is positive and highly significant $(p<0.0001)$ which suggests that the investment of firms affected by FIN 46 is more sensitive to their cash flows after their adoption for FIN 46. While the investmentcash flow sensitivity increased during the post implementation period for all firms included in the test, firms affected by FIN 46 have highly significant incremental effects. An increase in sensitivity of investment to cash flow for is an evidence of deterioration investment efficiency for firms affected by FIN 46. 


\section{Matched Pairs as Control Sample}

As discussed in descriptive statistics, fundamental characteristics (viz. size, profitability, cash flow etc.) of firms group 3 that is used as control sample are significantly different from those of firms in test sample (group 1 and2). To address this concern, I also use a matched pair control sample that is formed by identifying a matched firms for each firm in test sample by using industry, size and ROA as matching variables.. Specifically, for each firm-year observation in the test sample, I chose a matched pair from all the firms not affected by FIN 46, in the same year and same industry, requiring the closest ROA by restricting size difference less than 1 .

I estimate investment-cash flow sensitivity equation (11) with all observations in group 1 and 2 and matched pair sample. Results reported in Table 17 are consistent with those presented in the previous table, from the analyses using group 3 as control, with one exception that $F I N 46^{*} O C F$ become insignificant. The coefficient of POST ${ }^{*} F I N 46^{*} O C F$ is positive and highly significant $(\mathrm{p}<0.0001)$. Taken together, these findings suggests during the pre-implementation period firms subject to FIN 46 exhibit nontrivial sensitivity, which become incrementally significant during the postimplementation period.

\section{Deviation from Expected Investment Analyses}

In this subsection, I use three measures of investment efficiency, which are based on the deviation from the expected level of investments following prior studies (i.e., Biddle et al. 2009; Chen et al. 2011 etc.). These three measures, labeled as INVEFF1, INVEFF2 and INVEFF3, absolute values of residuals from equation (8), (9) and (10) respectively, which are used as proxies for how the investment level is deviated from the 
expected level in both directions. Using these three proxies for investment efficiency, I estimate equation (12) to test $\mathrm{H} 3$ by using the matched pairs as the control sample and results are reported in Table 18. The coefficients for FIN46 are positive and significant at p-value below 5\% level in all three estimations, suggesting that firms subject to FIN 46 are less inefficient in investment decisions compared to matched pair control firms. The coefficient of POST*FIN46 is negative and significant for all the three measures $(\mathrm{p}=0.096$ for $I N V E F F 1 ; \mathrm{p}=0.017$ for $I N V E F F 2 ; \mathrm{p}=0.052$ for $I N V E F F 3)$. These results suggest that the investment association are likely to improve for firms that are affected by FIN 46 (either consolidate VIEs or terminate/ restructure) and support hypothesis - H3. I then equations (13-15) that use a specification combining both expectation models (eq. 9-11) and testing model (eq. 12). The results of these alternative tests for $\mathrm{H} 3$ by using matched pairs as the control sample are presented in Table 19. The coefficients of $P O S T^{*} F I N 46$ are negative and significant for all the three models $(\mathrm{p}=0.071,0.024$ and 0.008 respectively). These results suggest that FIN 46 firms experience improved investment efficiency measured by deviation from expected investment compared to their matched pairs.

\section{Investment Efficiency: Firms Consolidated VIEs versus Firms Avoided}

\section{Consolidation (H4)}

Hypothesis 4 predicts firms consolidating VIEs are subject to a change in investment efficiency compared to firms that restructure or terminate VIEs to avoid consolidation. Consistent with previous section, I use two sets of measures- Investmentcash flow sensitivity and deviation from expected level of investments. 


\section{Investment-Cash Flow Sensitivity Tests}

The regression results for the test of investment-cash flow sensitivity are presented in Table 20. Here test sample includes firms consolidating VIEs (group 1) and the control sample includes firms that either terminate or restructure VIEs to avoid consolidation (group 2). The coefficient for market-to-book (MB) ratio is positive and highly significant $(\mathrm{p}<.0001)$ suggesting the level of investment is increasing in the firm's growth opportunity. The coefficients for $O C F$ is not significant however the interaction variable $F I N 46^{*} O C F$ is negative and significant $(\mathrm{p}=.028)$. The coefficient for $P O S T^{*}$ OCF positive and significant $(\mathrm{p}=.053)$. These results suggest that the investment-cash flow association is negative for the consolidating firms before FIN 46 and the sensitivity increases significantly after the implementation FIN 46 for both groups of firms.

The variable of interest is a three way interaction term $P O S T^{*} F I N 46^{*} O C F$, which tests the difference-in-differences for investment-cash flow sensitivity between pre-and post-implementation period comparing firms consolidating VIEs versus firms avoid consolidating. The coefficient of $P O S T^{*} F I N 46^{*} O C F$ is positive and marginally significant $(\mathrm{p}=.084$ two tailed test $)$ which suggests that the investment of firms consolidating VIEs is more sensitive to their cash flows after their adoption for FIN 46 compared firms that restructure or terminate VIEs. An increase in sensitivity of investment to cash flow for is an evidence of deterioration investment efficiency for firms affected by FIN 46.

\section{Deviation from Expected Investment Analyses}

I modify equations $(13,14$ and 15$)$ by replacing indicator variable FIN46 by two indicator variables $O N B O O K$ (takes value of 1 if firms consolidate VIEs in their financial 
statements) and $O F F B O O K$ (takes value of 1 if firms restructure or terminate VIEs to avoid consolidation) to test how the investment efficiency change in firms consolidating VIEs are different from those firms restructuring or terminating VIEs. I use matched pair firms as the control sample to estimate these models and results are presented in Table 21. The coefficients of POST*FIN46 are negative and significant for all the three models $(p=0.071,0.024$ and 0.008 respectively). These results suggest that FIN 46 firms experience improved investment efficiency measured by deviation from expected investment compared to their matched pairs. The coefficients for $P O S T^{*} O N B O O K$ are negative and significant ( $\mathrm{p}$ values are $0.054,0.019$ and 0.019 respectively) for all the three models and $P O S T^{*} O F F B O O K$ is negative and marginally significant in one measure only. This result supports my hypothesis H4.

However, for the other test (INVEFF) for $\mathrm{H} 4$, the same sample construction yields no results.

\section{Additional Tests: Group 1 vs. Matched Pairs}

Table 22 and Table 23 provide the results of the tests about the difference between group 1 and its matched pairs. The coefficient of POST*FIN46 is negative and significant for all the models. The same tests for group 2 and its matched pairs have no significant results. This represents the difference between group 1 and 2 from another perspective, suggesting that the investment efficiency for firms consolidating VIEs improves after FIN 46 compared to their peer firms, while firms restructuring or terminating VIEs don't experience such improvement compared to their peers. However, when measuring investment efficiency using investment - cash flow sensitivity, I find opposite results (untabulated). 


\section{Explanation for Opposite Results using Investment - Cash Flow Sensitivity}

I use two empirical proxies for investment efficiency, which are used in the extant literature, however, find completely opposite results. This subsection provides some explanations for the opposite results using investment-cash flow sensitivity. Prior literature shows that the extent to which firms are financial constrained affects investment - cash flow sensitivity (e.g., Fazzari et al. 2000). One possible explanation is that the higher investment-cash flow sensitivity for firms affected by FIN 46 could be due to the effect of financial constraints. Therefore, I partition the test sample into a financial constrained group and a financial unconstrained group to further examine the change of investment - cash flow sensitivity for FIN 46 firms in the pre- and post- FIN 46 periods. I construct an index following Kaplan and Zingales (1997) and Lamont et al. (2001) by using the following model:

$$
\begin{aligned}
\text { KZindex }= & -1.002 * \text { CashFlow }+0.283 * Q+3.139 * \text { Leverage }-39.368 * \text { Dividends } \\
& -1.315^{*} \text { CashHoldings }
\end{aligned}
$$

I assign the top (bottom) two quartiles as the financial constrained (unconstrained) group.

Table 24 present the regression results of H3 using no-impact firms as the control sample. For the financial constrained group, the coefficient of $P O S T^{*} F I N 46^{*} O C F$ is positive and highly significant $(p<0.0001)$. On the other hand, the coefficient of $P O S T^{*} F I N 46^{*} O C F$ for unconstraint group is marginally significant and smaller than that of constraint group.. The results of the same test using matched pairs as the control sample is reported in Table 25. The coefficient of POST_FIN46_OCF for the constrained group is positive and significant $(\mathrm{p}=0.001)$, while that for the unconstrained group is not significant $(\mathrm{p}=0.319)$. 
Thus, finding from this analysis provide explanation that higher investment-cash flow sensitivity for firms affected by FIN 46 is driven due to the financial constraints, which also suggest that this proxy measures different dimension of investment decision.

\section{SUMMARY}

This study examines the change in investment efficiency for firms affected by FIN 46. The results are mixed based on different proxies of investment efficiency. When using the investment - cash flow sensitivity to proxy for investment efficiency, I find firms affected by FIN 46 experience decreased investment efficiency indicated by increased investment sensitivity to cash flows, compared to firms reporting no material impact from FIN 46. The same results are found using matched pairs as the control sample of FIN 46 firms. I also find the investment of firms consolidating is more sensitive to cash flows after their adoption of FIN 46, compared to both the no-impact firms and matched pairs.

However, opposite results are found when using the deviation from expected investment as the proxy for investment efficiency. When comparing FIN 46 firms and their matched pairs, I find that FIN 46 firms experience improved investment efficiency measured by the deviation from expected investment after their adoption of FIN 46. Furthermore, I find firms consolidating VIEs experience improved investment efficiency measured by the deviation from expected investment after FIN 46 compared to their matched peers, while firms restructuring or terminating their VIEs don's exhibit such improvement. 
This study contributes the literature about the economic consequence of FIN 46. It also adds to a growing stream of literature about investment efficiency. Nevertheless, there are some limitations in this study. First, the small sample size affects the generalization of the empirical results. Second, the mixed results are based on different models. Third, the models to estimate investment efficiency is still evolving, thus the interpretation of the results is subject to the validity of different models. 


\section{CHAPTER V: CONCLUSION}

The Financial Accounting Standards Board (FASB) issued Interpretation No. 46 (FIN 46), Consolidation of Variable Interest Entities- An Interpretation of ARB No. 51, in January 2003 and revised it in December 2003, with an objective to improve the transparency of financial information. Under FIN 46, companies are required to consolidate special purpose entities (SPEs) on the financial statements if they are the primary beneficiaries of the SPEs, regardless of their voting interests in the entities. This study investigates whether the implementation of this new guidance affects accruals quality and investment efficiency of firms impacted by FIN 46.

The first part of my dissertation examines the effects of FIN 46 on accruals quality. I conduct tests using several different measures of accrual quality: the absolute value of performance-matched abnormal total accruals and working capital accruals suggested by Kothari et al. (2005); the accrual estimation errors of the DD 2002 model and its modified version suggested by McNichols (2002); the original DD 2002 accrual quality measures and its modified version suggested by McNichols (2002) and applied in Francis et al. (2005). I find that compared to firms reporting no material impact from FIN 46, firms impacted by FIN 46 experience worsened accrual quality, measured by the accrual estimation errors in the modified DD 2002 model (ABS_MDD) and the standard deviation of the residuals in the DD 2002 model and its modified version (STD_DD and $\left.S T D \_M D D\right)$, after consolidating, terminating or restructuring their VIEs. In additional analysis, I replace the control sample with a matched pair sample. The accrual quality measured by $A B S \_M D D$ and $S T D \_M D D$ have consistent results as before. 
I also examine the differences between the two subgroups in the FIN 46 firms (firms consolidating VIEs and firms terminating or restructuring VIEs). The results of the tests consistently show that the accrual quality measured by $A B S \_M D D$ and $S T D \_M D D$ for firms consolidating VIEs (group 1) are consistently lower compared to firms terminating or restructuring VIEs (group 2), no matter which control sample is used. The differential change in accrual quality between the two groups can be partially attributed to the facts that group 1 have pressure to manage earnings when the consolidation brings negative effects on earnings, which are confirmed by the empirical tests using signed abnormal accrual measures.

In the second part of the dissertation, I focus on the effects of FIN 46 on investment decisions made by affected firms. More specifically, I examine the investment efficiency of affected firms during the pre- and post-FIN46 periods. An important determinant of firms' economic productivity and future performance is the investment efficiency, which can be affected by accounting information quality. Poor accounting quality (such as the opaqueness of accounting information caused by the use of offbalance sheet items) exacerbates information asymmetry between firms and investors. Prior research suggests that information asymmetry can create either liquidity constraints or excess liquidity, both of which are associated with investment inefficiency (Biddle and Hilary 2006). Measuring investment efficiency using the deviation from expected investment (Chen et al. 2011), the empirical results show that firms affected by FIN 46 experience improved investment efficiency after the adoption of FIN 46, compared to a sample of matched firms that are not affected by FIN 46. Among these FIN 46 firms, firms consolidating VIEs experience greater improvement than those restructuring or 
terminating VIEs. However, when measuring investment efficiency using the investment - cash flow sensitivity, I find opposite results. The investment of firms affected by FIN 46 becomes more sensitive to cash flows after the adoption of FIN 46, compared to both no-impact firms and matched pairs. The investment of firms consolidating VIEs is more sensitive to cash flows compared to firms terminating or restructuring VIEs after their adoption of FIN 46.

The findings in my study are subject to some limitations. First, the small sample size of the test sample affects the estimation accuracy of the regression analysis. Second, the types of VIEs are not separated in the analysis. It is possible that the results are driven by certain category of VIEs, but not all. Third, the results are based on the measures of investment efficiency estimated from several models. The models to estimate investment efficiency are still evolving, thus the interpretation of the results is subject to the validity of different models.

My dissertation contributes to the literature in the following ways. First, it adds to the literature on impact of FIN 46. Prior studies investigate the economic consequences of FIN 46 from the perspective of market participants' responsiveness such as cost of capital (Callahan et al. 2012), analyst forecast precision and earnings response coefficients (Gurun et al. 2012). No extant research tests the impact of the changes in SPE consolidation rules on the quality of reported accounting numbers. This study fills this void by examining the effects of FIN 46 on accrual quality. Second, this study contributes to the stream of studies about off-balance sheet items in general. While prior studies provide evidence that firms with SPEs manage earnings through off-balance sheet activities, this study extends prior research by testing whether the changes in rules related 
to SPEs affect the quality of accruals. Third, this study contributes to the literature that examines how mandatory changes in accounting standards affect financial reporting quality. Fourth, it contributes to the literature by extending a relatively smaller but growing stream of research on how the quality of accounting information affects investment efficiency. 
TABLE 1 Panel A: Sample Deviation - AA Measures

\section{Group 1:}

Number of firms found in 10-K wizard 260

Number of firms that have non-missing values for AA measures $\quad 184$

After excluding financial firms 144

Number of observations for non-financial firms for year 1988-2012 2580

Number of observations for non-financial firms for year 1998-2007 1225

\section{Group 2:}

Number of firms found in 10-K wizard 113

Number of firms that have non-missing values for AA measures $\quad 85$

$\begin{array}{ll}\text { After excluding financial firms } & 69\end{array}$

Number of observations for non-financial firms for year 1988-2012 1301

Number of observations for non-financial firms for year 1998-2007 592

\section{Group 3:}

Number of firms found in 10-K wizard 1077

Number of firms that have non-missing values for AA measures $\quad 775$

$\begin{array}{ll}\text { After excluding financial firms } & 719\end{array}$

Number of observations for non-financial firms for year 1988-2012 10632

Number of observations for non-financial firms for year 1998-2007 5690

Table 1 panel A provides the sample derivation for empirical analyses of abnormal accrual measures: abnormal total accruals $(A A)$, working capital accrual (AWCA), performance-matched abnormal total accrual $\left(P M \_A A\right)$ and working capital accruals ( $\left.P M \_A W C A\right)$. Group 1 is defined for firms consolidating VIEs. Group 2 is defined for firms restructuring or terminating VIES to avoid consolidating. Group 3 is defined for firms reporting no (material) impact from FIN 46. Searching using $10-\mathrm{K}$ wizard, 260 firms are found in group 1 . The sample is narrowed down to 184 firms after excluding firms with missing observations to estimate abnormal accruals. After deleting firms in financial industries (SIC 6000-6999), 144 firms left. There are 2580 firm-year observations from $1988-2012$ for group 1 . Since my testing period is $1998-2007$, the final sample for group 1 includes 1225 firm-year observations. Following the same sample deviation process, Group 2 and Group 3 have 592 and 5690 firm-year observations respectively from 1998 -2007 . 
TABLE 1 Panel B: Sample Deviation - DD Measures

\section{Group 1:}

Number of firms found in 10-K wizard 260

Number of firms that have non-missing values for DD, MDD 121

After excluding financial firms 104

Number of observations for non-financial firms for year 1988 - 2012 1074

Number of observations for non-financial firms for year 1998-2007 509

\section{Group 2:}

Number of firms found in 10-K wizard 113

Number of firms that have non-missing values for DD, MDD 49

After excluding financial firms $\quad 45$

Number of observations for non-financial firms for year 1988-2012 360

Number of observations for non-financial firms for year 1998 - 2007 159

\section{Group 3:}

$\begin{array}{ll}\text { Number of firms found in 10-K wizard } & 1077\end{array}$

Number of firms that have non-missing values for DD, MDD 593

After excluding financial firms $\quad 562$

Number of observations for non-financial firms for year 1988-2012 4672

Number of observations for non-financial firms for year 1998-2007 2690

Table 1 panel B provides the sample derivation for the tests on accrual quality measured using the accrual estimation errors from the DD model. Group 1 is defined for firms consolidating VIEs.

Group 2 is defined for firms restructuring or terminating VIES to avoid consolidating. Group 3 is defined for firms reporting no (material) impact from FIN 46. Searching using 10-K wizard, 260 firms are found in group 1. The sample is narrowed down to 121 firms after excluding firms with missing observations to estimate DD and MDD. After deleting firms in financial industries (SIC 6000-6999), 104 firms left. There are 1074 firm-year observations from 1988 - 2012 for group 1. Since my testing period is 1998 - 2007, the final sample for group 1 includes 509 firm-year observations. Following the same sample deviation process, Group 2 and Group 3 have 159 and 2690 firm-year observations respectively from $1998-2007$. 
TABLE 2 Panel A: Descriptive Statistics - Sample for AA Measures

\begin{tabular}{|c|c|c|c|c|c|}
\hline \multicolumn{6}{|l|}{ Group 1} \\
\hline & Mean & Q1 & Median & Q3 & SD \\
\hline Size & 7.693 & 6.488 & 7.931 & 9.243 & 2.116 \\
\hline Leverage & 0.628 & 0.491 & 0.663 & 0.761 & 0.224 \\
\hline OCF & 0.064 & 0.039 & 0.076 & 0.122 & 0.147 \\
\hline SGROWTH & 0.122 & -0.004 & 0.050 & 0.159 & 0.385 \\
\hline ROA & 0.005 & 0.008 & 0.033 & 0.059 & 0.149 \\
\hline LOG_CYCLE & 4.533 & 4.059 & 4.561 & 5.001 & 0.837 \\
\hline$A A$ & -0.007 & -0.034 & -0.001 & 0.028 & 0.097 \\
\hline$A W C A$ & -0.003 & -0.028 & -0.002 & 0.026 & 0.093 \\
\hline PMAA & 0.032 & 0.006 & 0.039 & 0.068 & 0.097 \\
\hline PMAWCA & 0.021 & -0.004 & 0.023 & 0.050 & 0.093 \\
\hline$A B S \_A A$ & 0.060 & 0.014 & 0.031 & 0.069 & 0.089 \\
\hline$A B S \_A W C A$ & 0.057 & 0.012 & 0.027 & 0.060 & 0.091 \\
\hline$A B S \_P M A A$ & 0.072 & 0.027 & 0.049 & 0.083 & 0.084 \\
\hline ABS_PMAWCA & 0.062 & 0.017 & 0.035 & 0.068 & 0.091 \\
\hline \# of firms & 144 & & & & \\
\hline \# of observations & 1225 & & & & \\
\hline
\end{tabular}

Group 2

Size

Leverage

OCF

SGROWTH

ROA

LOG_CYCLE

$A A$

AWCA

PMAA

PMAWCA

ABS_AA

ABS_AWCA

ABS_PMAA

ABS_PMAWCA

\# of firms

\# of observations

\begin{tabular}{ccccc} 
Mean & Q1 & Median & Q3 & SD \\
\hline 7.858 & 6.446 & 7.673 & 9.266 & 1.959 \\
0.632 & 0.487 & 0.642 & 0.773 & 0.242 \\
0.084 & 0.041 & 0.077 & 0.122 & 0.090 \\
0.114 & -0.014 & 0.042 & 0.148 & 0.305 \\
0.014 & 0.000 & 0.028 & 0.055 & 0.104 \\
4.547 & 4.092 & 4.599 & 4.937 & 0.702 \\
-0.010 & -0.043 & -0.005 & 0.027 & 0.088 \\
-0.008 & -0.031 & -0.005 & 0.020 & 0.080 \\
0.030 & -0.004 & 0.034 & 0.066 & 0.088 \\
0.016 & -0.006 & 0.019 & 0.045 & 0.080 \\
0.060 & 0.015 & 0.036 & 0.074 & 0.079 \\
0.051 & 0.011 & 0.025 & 0.060 & 0.078 \\
0.069 & 0.025 & 0.046 & 0.083 & 0.080 \\
0.055 & 0.015 & 0.032 & 0.063 & 0.078
\end{tabular}

69

592

Group 3 


\begin{tabular}{|c|c|c|c|c|c|}
\hline Size & 5.173 & 3.701 & 5.179 & 6.581 & 2.142 \\
\hline Leverage & 0.568 & 0.278 & 0.498 & 0.701 & 0.470 \\
\hline OCF & -0.023 & -0.056 & 0.058 & 0.127 & 0.323 \\
\hline SGROWTH & 0.132 & -0.019 & 0.068 & 0.222 & 0.406 \\
\hline$R O A$ & -0.111 & -0.140 & 0.014 & 0.067 & 0.359 \\
\hline LOG_CYCLE & 4.763 & 4.369 & 4.766 & 5.173 & 0.715 \\
\hline$A \boldsymbol{A}$ & -0.028 & -0.070 & -0.008 & 0.045 & 0.191 \\
\hline$A W C A$ & -0.020 & -0.058 & -0.006 & 0.041 & 0.180 \\
\hline PMAA & 0.012 & -0.030 & 0.031 & 0.085 & 0.191 \\
\hline PMAWCA & 0.004 & -0.034 & 0.018 & 0.065 & 0.180 \\
\hline$A B S \_A A$ & 0.116 & 0.024 & 0.058 & 0.134 & 0.160 \\
\hline$A B S \_A W C A$ & 0.107 & 0.020 & 0.049 & 0.121 & 0.153 \\
\hline$A B S \_P M A A$ & 0.121 & 0.031 & 0.067 & 0.139 & 0.156 \\
\hline$A B S \_P M A W C A$ & 0.109 & 0.023 & 0.054 & 0.123 & 0.151 \\
\hline \# of firms & 719 & & & & \\
\hline \# of observations & 5690 & & & & \\
\hline
\end{tabular}

Table 2 panel A provides the descriptive statistics of the (performance-matched) abnormal total accruals, (performance-matched) working capital accruals and the control variables for the three groups of firms from 1998 -2007. Variable descriptions are as follows: $A B S \_A A$ is the absolute values of abnormal total accruals; $A B S \_A W C A$ is the absolute value of abnormal working capital accruals; $A B S \_P M A A$ is the absolute values of performance-matched abnormal total accruals; $A B S \_P M A W C A$ is the absolute values of performance-matched working capital accruals; SIZE is logarithm of lagged total assets; Leverage is measured as total liability divided by total assets; $O C F$ is measured as operating cash flow divided by lagged total assets; SGROWTH is measured as the change in sales divided by lagged total assets; $R O A$ is the income before extraordinary items divided by lagged total assets; $L O G \_C Y C L E$ is logarithm of operating cycle, which is measured as the sum of average days of accounts receivable and average days of inventory. 
TABLE 2 Panel B: Descriptive Statistics - Sample for DD Measures

\begin{tabular}{|c|c|c|c|c|c|}
\hline \multicolumn{6}{|l|}{ Group 1} \\
\hline & Mean & Q1 & Median & Q3 & SD \\
\hline Size & 7.301 & 6.335 & 7.550 & 8.800 & 2.060 \\
\hline Leverage & 0.632 & 0.463 & 0.674 & 0.757 & 0.242 \\
\hline OCF & 0.058 & 0.034 & 0.071 & 0.116 & 0.141 \\
\hline SGROWTH & 0.109 & -0.007 & 0.048 & 0.179 & 0.341 \\
\hline ROA & -0.004 & 0.007 & 0.030 & 0.055 & 0.164 \\
\hline LOG_CYCLE & 4.519 & 4.179 & 4.534 & 4.925 & 0.744 \\
\hline$A B S \_D D$ & 0.043 & 0.010 & 0.024 & 0.048 & 0.060 \\
\hline ABS_MDD & 0.034 & 0.008 & 0.020 & 0.041 & 0.045 \\
\hline STD_DD & 0.046 & 0.018 & 0.031 & 0.052 & 0.058 \\
\hline STD_MDD & 0.032 & 0.014 & 0.023 & 0.037 & 0.037 \\
\hline \# of firms & 104 & & & & \\
\hline \# of observations & 509 & & & & \\
\hline
\end{tabular}

Group 2

Size

Leverage

OCF

SGROWTH

ROA

LOG_CYCLE

ABS_DD

ABS_MDD

STD_DD

STD_MDD

\# of firms

\# of observations

\begin{tabular}{ccccc} 
Mean & Q1 & Median & Q3 & SD \\
\hline 6.836 & 5.936 & 7.013 & 7.836 & 1.597 \\
0.524 & 0.279 & 0.529 & 0.672 & 0.260 \\
0.070 & 0.020 & 0.078 & 0.120 & 0.108 \\
0.192 & -0.020 & 0.060 & 0.220 & 0.442 \\
-0.012 & -0.015 & 0.030 & 0.060 & 0.191 \\
4.690 & 4.298 & 4.723 & 5.132 & 0.555 \\
0.037 & 0.012 & 0.028 & 0.051 & 0.033 \\
0.031 & 0.013 & 0.023 & 0.042 & 0.027 \\
0.043 & 0.021 & 0.038 & 0.059 & 0.027 \\
0.037 & 0.021 & 0.032 & 0.045 & 0.025
\end{tabular}

45

159

Group 3

\begin{tabular}{lccccc} 
& Mean & Q1 & Median & Q3 & SD \\
\cline { 2 - 5 } Size & 4.767 & 3.297 & 4.720 & 6.187 & 2.098 \\
Leverage & 0.525 & 0.236 & 0.446 & 0.683 & 0.418 \\
OCF & -0.049 & -0.099 & 0.043 & 0.120 & 0.328 \\
SGROWTH & 0.139 & -0.032 & 0.069 & 0.235 & 0.428 \\
ROA & -0.149 & -0.212 & 0.005 & 0.067 & 0.425 \\
LOG_CYCLE & 4.851 & 4.453 & 4.844 & 5.223 & 0.738 \\
ABS_DD & 0.066 & 0.018 & 0.041 & 0.083 & 0.076 \\
ABS_MDD & 0.058 & 0.015 & 0.034 & 0.071 & 0.071
\end{tabular}




\begin{tabular}{lllllll} 
STD_DD & & 0.078 & 0.030 & 0.054 & 0.097 & 0.080 \\
STD_MDD & & 0.065 & 0.023 & 0.041 & 0.082 & 0.069 \\
\# of firms & 562 & & & & & \\
\# of observations & 2690 & & & & & \\
\hline
\end{tabular}

Table 2 panel B reports the descriptive statistics for the accrual estimation errors from Dechow and Dichev (2002) model, the standard deviation for the accrual estimation errors developed by Dechow and Dichev (2002), and the control variables in the regression models. $A B S \_D D$ is the absolute value of the estimation errors from DD 2002 model; $A B S \_M D D$ is the absolute value of the estimation errors from modified DD 2002 model; STD_DD is the standard deviation of the estimation errors from DD 2002 model; STD_MDD is the standard deviation of the estimation error from modified DD 2002 model; SIZE is logarithm of lagged total assets; Leverage is measured as total liability divided by total assets; $O C F$ is measured as operating cash flow divided by lagged total assets; $S G R O W T H$ is measured as the change in sales divided by lagged total assets; $R O A$ is the income before extraordinary items divided by lagged total assets; $L O G_{-} C Y C L E$ is logarithm of operating cycle, which is measured as the sum of average days of accounts receivable and average days of inventory. 
TABLE 3: Regression of Absolute Value of Performance-Matched Abnormal Accruals (H1)

\begin{tabular}{|c|c|c|c|c|}
\hline \multirow[b]{2}{*}{ Variable } & \multicolumn{2}{|c|}{$\underline{A B S \_P M A A}$} & \multicolumn{2}{|c|}{ ABS_PMAWCA } \\
\hline & Coefficient & p-value & Coefficient & p-value \\
\hline Intercept & 0.072 & $<0.0001$ & 0.059 & $<0.0001$ \\
\hline POST & -0.006 & 0.097 & -0.004 & 0.187 \\
\hline FIN46 & 0.000 & 0.970 & -0.004 & 0.378 \\
\hline POST*FIN46 & 0.007 & 0.304 & 0.010 & 0.142 \\
\hline Leverage & 0.046 & $<0.0001$ & 0.043 & $<0.0001$ \\
\hline SGROWTH & 0.058 & $<0.0001$ & 0.057 & $<0.0001$ \\
\hline ROA & -0.101 & $<0.0001$ & -0.094 & $<0.0001$ \\
\hline SIZE & -0.012 & $<0.0001$ & -0.012 & $<0.0001$ \\
\hline OCF & -0.063 & $<0.0001$ & -0.063 & $<0.0001$ \\
\hline OCF2 & 0.010 & $<0.0001$ & 0.013 & $<0.0001$ \\
\hline LOG_CYCLE & 0.014 & $<0.0001$ & 0.014 & $<0.0001$ \\
\hline $\operatorname{Adj} . R^{2}$ & $27.50 \%$ & & $29.28 \%$ & \\
\hline $\mathbf{N}$ & 4670 & & 4670 & \\
\hline
\end{tabular}

Table 3 provides the regression results of the following model:

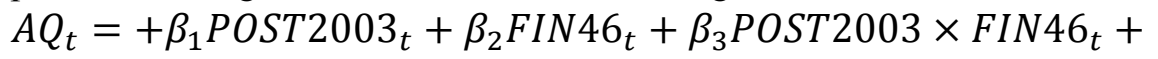

$$
\begin{aligned}
& \beta_{4} L E V E R A G E_{t}+\beta_{5} \text { GROWTH }_{t}+\beta_{6} S I Z E_{t}+\beta_{7} R O A_{t}+\beta_{8} O C F_{t}+ \\
& \beta_{9} O C F 2_{t}+\beta_{10} L O G_{-} C Y C L E_{t}+\varepsilon_{t}
\end{aligned}
$$

$A Q$ here are the performance-matched abnormal total accruals ( $\left.A B S \_P M A A\right)$ and the performance-matched abnormal working capital accruals (ABS_PMA $\bar{A} C A)$. ABS_PMAA is the absolute values of performance-matched abnormal total accruals; $A B S \_P M A W C A$ is the absolute values of performance-matched working capital accruals. POST is an indicator variable for testing years after 2003; FIN46 is an indicator variable for firms affected by FIN 46, that is, firms having VIEs subject to consolidation requirement. These firms chose either consolidated VIEs or 
keeping VIEs off the financial statement by restructuring or terminating VIEs; SIZE is logarithm of lagged total assets; Leverage is measured as total liability divided by total assets; $O C F$ is measured as operating cash flow divided by lagged total assets; $O C F 2$ is the quadratic term of $O C F$; SGROWTH is measured as the change in sales divided by lagged total assets; ROA is the income before extraordinary items divided by lagged total assets; $L O G \_C Y C L E$ is logarithm of operating cycle, which is measured as the sum of average days of accounts receivable and average days of inventory. All three groups of firms in the sample are used in estimating regressions, where the test sample consists of observations in Groups 1 and 2, and control sample with observations in Group 3. 
TABLE 4: Regression of Accrual Estimation Errors (H1)

\begin{tabular}{|c|c|c|c|c|}
\hline \multirow[b]{2}{*}{ Variable } & \multicolumn{2}{|c|}{$\underline{A B S \_D D}$} & \multicolumn{2}{|c|}{$\underline{A B S \_M D D}$} \\
\hline & Coefficient & p-value & Coefficient & p-value \\
\hline Intercept & 0.047 & 0.007 & 0.030 & 0.047 \\
\hline POST & -0.004 & 0.406 & 0.000 & 0.972 \\
\hline FIN46 & 0.000 & 0.960 & -0.004 & 0.479 \\
\hline POST ${ }^{*} F I N 46$ & 0.012 & 0.205 & 0.017 & 0.032 \\
\hline Leverage & 0.039 & $<0.0001$ & 0.037 & $<0.0001$ \\
\hline SGROWTH & 0.025 & $<0.0001$ & 0.025 & $<0.0001$ \\
\hline SIZE & -0.010 & $<0.0001$ & -0.009 & $<0.0001$ \\
\hline ROA & -0.045 & $<0.0001$ & -0.050 & $<0.0001$ \\
\hline LOG_CYCLE & 0.01 & 0.002 & 0.010 & 0.000 \\
\hline Adj. $\mathbf{R}^{2}$ & $18.32 \%$ & & $22.00 \%$ & \\
\hline $\mathbf{N}$ & 1557 & & 1557 & \\
\hline
\end{tabular}

Table 4 provides the regression results of the following model:

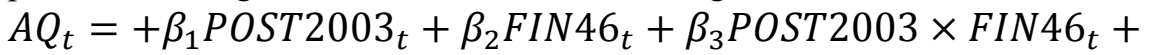

$$
\begin{aligned}
& \beta_{4} L E V E R A G E_{t}+\beta_{5} G R O W T H_{t}+\beta_{6} S I Z E_{t}+\beta_{7} R O A_{t}+\beta_{8} O C F_{t}+ \\
& \beta_{9} O C F 2_{t}+\beta_{10} L O G_{-} C Y C L E_{t}+\varepsilon_{t}
\end{aligned}
$$

$A Q$ here are $A B S \_D D$ and $A B S \_M D D$. $A B S \_D D$ is the absolute value of the estimation errors from DD 2002 model; $A B S \_M \bar{D} D$ is the absolute value of the estimation errors from modified DD 2002 model; POST is an indicator variable for testing years after 2003; FIN46 is an indicator variable for firms affected by FIN 46, that is, firms having VIEs subject to consolidation requirement. These firms chose either consolidated VIEs or keeping VIEs off the financial statement by restructuring or terminating VIEs; SIZE is logarithm of lagged total assets; Leverage is measured as total liability divided by total assets; SGROWTH is measured as the change in sales divided by lagged total assets; $R O A$ is the income before extraordinary items divided by lagged total assets; $L O G_{-} C Y C L E$ is logarithm of operating cycle, which is measured as the sum of average days of accounts receivable and average days of inventory. All three groups of firms in the sample are used in estimating regressions, where the test sample consists of observations in Groups 1 and 2, and control sample with observations in Group 3. 


\section{TABLE 5: Regression of Standard Deviation of Accrual Estimation Errors (H1)}

\begin{tabular}{|c|c|c|c|c|}
\hline \multirow[b]{2}{*}{ Variable } & \multicolumn{2}{|c|}{$\underline{S T D \_D D}$} & \multicolumn{2}{|c|}{$\underline{S T D \_M D D}$} \\
\hline & Coefficient & p-value & Coefficient & p-value \\
\hline Intercept & 0.016 & 0.036 & 0.025 & 0.049 \\
\hline POST & -0.018 & $<0.0001$ & -0.007 & 0.026 \\
\hline FIN46 & -0.007 & 0.337 & -0.005 & 0.321 \\
\hline POST*FIN46 & 0.019 & 0.035 & 0.012 & 0.075 \\
\hline Leverage & 0.025 & 0.001 & 0.020 & 0.000 \\
\hline SGROWTH & 0.026 & $<0.0001$ & 0.021 & $<0.0001$ \\
\hline SIZE & -0.012 & $<0.0001$ & -0.010 & $<0.0001$ \\
\hline ROA & -0.024 & 0.006 & -0.022 & 0.000 \\
\hline LOG_CYCLE & 0.024 & $<0.0001$ & 0.016 & $<0.0001$ \\
\hline Adj. $R^{2}$ & $22.23 \%$ & & $24.92 \%$ & \\
\hline $\mathbf{N}$ & 1321 & & 1320 & \\
\hline
\end{tabular}

Table 5 provides the regression results of the following model:

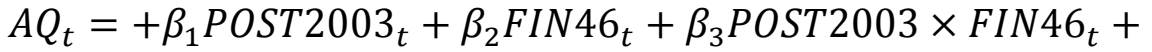

$$
\begin{aligned}
& \beta_{4} L E V E R A G E_{t}+\beta_{5} G R O W T H_{t}+\beta_{6} S I Z E_{t}+\beta_{7} R O A_{t}+\beta_{8} O C F_{t}+ \\
& \beta_{9} O C F 2_{t}+\beta_{10} L O G_{-} C Y C L E_{t}+\varepsilon_{t}
\end{aligned}
$$

$A Q$ here are $S T D \_D D$ and $S T D \_M D D$. $S T D_{-} D D$ is the standard deviation of the estimation errors from DD 2002 model; $S T D \_M \bar{D} D$ is the standard deviation of the estimation error from modified DD 2002 model; POST is an indicator variable for testing years after 2003; FIN46 is an indicator variable for firms affected by FIN 46, that is, firms having VIEs subject to consolidation requirement. These firms chose either consolidated VIEs or keeping VIEs off the financial statement by restructuring or terminating VIEs; SIZE is logarithm of lagged total assets; Leverage is measured as total liability divided by total assets; SGROWTH is measured as the change in sales divided by lagged total assets; $R O A$ is the income before extraordinary items divided by lagged total assets; $L O G \_C Y C L E$ is logarithm of operating cycle, which is measured as the sum of average days of accounts receivable and average days of inventory. All three groups of firms in the sample are used in estimating regressions, where the test sample consists of observations in Groups 1 and 2, and control sample with observations in Group 3. 
TABLE 6: Regression of Absolute Value of Performance-Matched Abnormal Accruals (H2)

\begin{tabular}{|c|c|c|c|c|}
\hline \multirow[b]{2}{*}{ Variable } & \multicolumn{2}{|c|}{ ABS PMAA } & \multicolumn{2}{|c|}{ ABS PMAWCA } \\
\hline & Coefficient & p-value & Coefficient & p-value \\
\hline Intercept & 0.072 & $<0.0001$ & 0.059 & $<0.0001$ \\
\hline POST & -0.006 & 0.097 & -0.004 & 0.187 \\
\hline FIN46_CON & -0.001 & 0.894 & -0.002 & 0.699 \\
\hline FIN46_OFF & 0.002 & 0.781 & -0.009 & 0.238 \\
\hline POST*FIN46_CON & 0.006 & 0.420 & 0.008 & 0.309 \\
\hline POST*FIN46_OFF & 0.008 & 0.465 & 0.013 & 0.191 \\
\hline Leverage & 0.046 & $<0.0001$ & 0.042 & $<0.0001$ \\
\hline SGROWTH & 0.058 & $<0.0001$ & 0.058 & $<0.0001$ \\
\hline ROA & -0.101 & $<0.0001$ & -0.094 & $<0.0001$ \\
\hline SIZE & -0.012 & $<0.0001$ & -0.012 & $<0.0001$ \\
\hline OCF & -0.063 & $<0.0001$ & -0.063 & $<0.0001$ \\
\hline OCF2 & 0.010 & $<0.0001$ & 0.013 & $<0.0001$ \\
\hline LOG_CYCLE & 0.014 & $<0.0001$ & 0.014 & $<0.0001$ \\
\hline Adj. $R^{2}$ & $27.47 \%$ & & $29.26 \%$ & \\
\hline $\mathbf{N}$ & 4670 & & 4670 & \\
\hline
\end{tabular}

Table 6 provides the regression results of the following model:

$A Q_{t}=\beta_{0}+\beta_{1}$ POST $2003_{t}+\delta_{1}$ FIN 46_CON $_{t}+\delta_{2}$ FIN46_OFF $t+\delta_{3}$ POST2003 $\times$

FIN46_CON ${ }_{t}+\delta_{4}$ POST2003 $\times$ FIN46_OFF $F_{t}+\beta_{4} L E V E R A G E_{t}+\beta_{5}$ GROWTH $_{t}+$

$\beta_{6} S I Z E_{t}+\beta_{7} R O A_{t}+\beta_{8} O C F_{t}+\beta_{9} O C F 2_{t}+\beta_{10} L O G_{-} C Y C L E_{t}+\varepsilon_{\mathrm{t}}$

$A Q$ here are $A B S \_P M A A$ and $A B S \_P M A W C A$. $A B S \_P M A A$ is the absolute values of performance-matched abnormal total accruals; $A B \bar{S} P M A W C A$ is the absolute values of performance-matched working capital accruals; $P O \bar{S} T$ is an indicator variable for testing years 
after 2003; FIN46_CON is an indicator variable for firms in groups 1- firms consolidating VIEs; FIN46_OFF is an indicator variable for firms in group 2- firms avoiding consolidating by keeping VIEs off the financial statement. They terminated or restructured VIEs; SIZE is logarithm of lagged total assets; Leverage is measured as total liability divided by total assets; $O C F$ is measured as operating cash flow divided by lagged total assets; $O C F 2$ is the quadratic term of $O C F$; $S G R O W T H$ is measured as the change in sales divided by lagged total assets; $R O A$ is the income before extraordinary items divided by lagged total assets; $L O G_{-} C Y C L E$ is logarithm of operating cycle, which is measured as the sum of average days of accounts receivable and average days of inventory. All three groups of firms in the sample are used in estimating regressions, where the test sample consists of observations in Groups 1 and 2, and control sample with observations in Group 3. 


\begin{tabular}{|c|c|c|c|c|}
\hline \multirow[b]{2}{*}{ Variable } & \multicolumn{2}{|c|}{$\underline{A B S \quad D D}$} & \multicolumn{2}{|c|}{$\underline{A B S \quad M D D}$} \\
\hline & $\underline{\text { Coefficient }}$ & p-value & Coefficient & p-value \\
\hline Intercept & 0.046 & 0.008 & 0.030 & 0.048 \\
\hline POST & -0.003 & 0.419 & 0.000 & 0.960 \\
\hline FIN46_CON & 0.003 & 0.692 & -0.002 & 0.765 \\
\hline FIN46_OFF & -0.008 & 0.500 & -0.009 & 0.365 \\
\hline POST*FIN46_CON & 0.014 & 0.170 & 0.018 & 0.042 \\
\hline POST*FIN46_OFF & 0.003 & 0.837 & 0.013 & 0.372 \\
\hline Leverage & 0.038 & $<0.0001$ & 0.036 & $<0.0001$ \\
\hline SGROWTH & 0.026 & $<0.0001$ & 0.025 & $<0.0001$ \\
\hline SIZE & -0.011 & $<0.0001$ & -0.010 & $<0.0001$ \\
\hline ROA & -0.045 & $<0.0001$ & -0.050 & $<0.0001$ \\
\hline$L O G \_C Y C L E$ & 0.010 & 0.001 & 0.010 & 0.000 \\
\hline Adj. $R^{2}$ & $18.40 \%$ & & $21.98 \%$ & \\
\hline $\mathbf{N}$ & 1557 & & 1557 & \\
\hline
\end{tabular}

Table 7 provides the regression results of the following model:

$A Q_{t}=\beta_{0}+\beta_{1}$ POST 2003 $_{t}+\delta_{1}$ FIN 46_CON $_{t}+\delta_{2}$ FIN46_OFF $t+\delta_{3}$ POST $2003 \times$ FIN46_CON $+\delta_{4}$ POST2003 $\times$ FIN46_OFF ${ }_{t}+\beta_{4} L E V E R A G E_{t}+\beta_{5}$ GROWTH $H_{t}+$ $\beta_{6} S I Z E_{t}+\beta_{7} R O A_{t}+\beta_{8} O C F_{t}+\beta_{9} O C F 2_{t}+\beta_{10} L O G_{-} C Y C L E_{t}+\varepsilon_{\mathrm{t}}$

$A Q$ here are $A B S \_D D$ and $A B S \_M D D$. $A B S \_D D$ is the absolute value of the estimation errors from DD 2002 model; $A B S \_M \bar{D} D$ is the absolute value of the estimation errors from modified DD 2002 model; POST is an indicator variable for testing years after 2003; FIN46_CON is an indicator variable for firms in groups 1- firms consolidating VIEs; FIN46_OFF is an indicator variable for firms in group 2- firms avoiding consolidating by keeping VIEs off the financial statement. They terminated or restructured VIEs; SIZE is logarithm of lagged total assets; Leverage is measured as total liability divided by total assets; SGROWTH is measured as the change in sales divided by lagged total assets; $R O A$ is the income before extraordinary items 
divided by lagged total assets; $L O G \_C Y C L E$ is logarithm of operating cycle, which is measured as the sum of average days of accounts receivable and average days of inventory. All three groups of firms in the sample are used in estimating regressions, where the test sample consists of observations in Groups 1 and 2, and control sample with observations in Group 3. 


\section{TABLE 8: Regression of Standard Deviation of Accrual Estimation Errors (H2)}

\begin{tabular}{|c|c|c|c|c|}
\hline \multirow[b]{2}{*}{ Variable } & \multicolumn{2}{|c|}{$\underline{S T D D D}$} & \multicolumn{2}{|c|}{$\underline{S T D} M D D$} \\
\hline & $\underline{\text { Coefficient }}$ & p-value & $\underline{\text { Coefficient }}$ & p-value \\
\hline Intercept & 0.016 & 0.370 & 0.025 & 0.048 \\
\hline POST & -0.018 & $<0.0001$ & -0.007 & 0.026 \\
\hline FIN46_CON & -0.004 & 0.668 & -0.005 & 0.437 \\
\hline FIN46_OFF & -0.013 & 0.264 & -0.006 & 0.516 \\
\hline POST*FIN46_CON & 0.023 & 0.026 & 0.014 & 0.051 \\
\hline POST*FIN46_OFF & 0.008 & 0.624 & 0.003 & 0.768 \\
\hline Leverage & 0.024 & 0.001 & 0.020 & 0.000 \\
\hline SGROWTH & 0.026 & $<0.0001$ & 0.021 & $<0.0001$ \\
\hline SIZE & -0.012 & $<0.0001$ & -0.010 & $<0.0001$ \\
\hline ROA & -0.024 & 0.005 & -0.022 & 0.000 \\
\hline LOG_CYCLE & 0.025 & $<0.0001$ & 0.016 & $<0.0001$ \\
\hline $\operatorname{Adj} \cdot \mathbf{R}^{2}$ & $22.37 \%$ & & $24.91 \%$ & \\
\hline $\mathbf{N}$ & 1321 & & 1320 & \\
\hline
\end{tabular}

Table 8 provides the regression results of the following model:

$A Q_{t}=\beta_{0}+\beta_{1}$ POST2003 $t+\delta_{1}$ FIN46_CON $+\delta_{2}$ FIN46_OFF $F_{t}+\delta_{3}$ POST2003 $\times$ FIN46_CON ${ }_{t}+\delta_{4}$ POST2003 $\times$ FIN46_OFF $F_{t}+\beta_{4}$ LEVERAGE $_{t}+\beta_{5}$ GROWTH $_{t}+$ $\beta_{6} S I Z E_{t}+\beta_{7} R O A_{t}+\beta_{8} O C F_{t}+\beta_{9} O C F 2_{t}+\beta_{10} L O G_{-} C Y C L E_{t}+\varepsilon_{\mathrm{t}}$

$A Q$ here are $S T D \_D D$ and $S T D \_M D D$. $S T D_{-} D D$ is the standard deviation of the estimation errors from DD 2002 model; $S T D_{-} M \bar{D} D$ is the standard deviation of the estimation error from modified DD 2002 model; POST is an indicator variable for testing years after 2003; FIN46_CON is an indicator variable for firms in groups 1- firms consolidating VIEs; FIN46_OFF is an indicator variable for firms in group 2- firms avoiding consolidating by keeping VIEs off the financial statement. They terminated or restructured VIEs; SIZE is logarithm of lagged total assets; Leverage is measured as total liability divided by total assets; SGROWTH is measured as the 
change in sales divided by lagged total assets; $R O A$ is the income before extraordinary items divided by lagged total assets; $L O G_{-} C Y C L E$ is logarithm of operating cycle, which is measured as the sum of average days of accounts receivable and average days of inventory. All three groups of firms in the sample are used in estimating regressions, where the test sample consists of observations in Groups 1 and 2, and control sample with observations in Group 3. 
Table 9 Panel A: Additional Analysis of H1

- FIN 46 Firms and Matched Pairs

\begin{tabular}{|c|c|c|c|c|c|c|c|}
\hline & \multicolumn{3}{|c|}{ FIN46=1 (Group 1\&2) } & \multicolumn{3}{|c|}{ FIN46=0 (matched pair) } & \multirow{2}{*}{$\begin{array}{c}\text { Difference- } \\
\text { in } \\
\text { differences }\end{array}$} \\
\hline & $\begin{array}{l}\text { pre- } \\
\underline{2003}\end{array}$ & $\begin{array}{l}\text { post- } \\
\underline{2003}\end{array}$ & Change & pre-2003 & $\begin{array}{l}\text { post- } \\
\underline{2003}\end{array}$ & Change & \\
\hline \multicolumn{8}{|l|}{ Accrual Quality } \\
\hline ABS_DD & 0.040 & 0.039 & 0.001 & 0.037 & 0.028 & $(0.009)^{* * *}$ & $0.011 * *$ \\
\hline$N$ & 991 & 443 & & 865 & 401 & & \\
\hline ABS_MDD & 0.030 & 0.032 & 0.002 & 0.030 & 0.024 & $(0.006)^{* * *}$ & $0.008 * *$ \\
\hline$N$ & 991 & 443 & & 865 & 401 & & \\
\hline STD_DD & 0.040 & 0.044 & 0.004 & 0.036 & 0.034 & $(0.002)$ & $0.010 * *$ \\
\hline$N$ & 551 & 360 & & 459 & 325 & & \\
\hline STD_MDD & 0.029 & 0.036 & $0.007 * *$ & 0.029 & 0.029 & 0.000 & $0.007 * *$ \\
\hline$N$ & 551 & 360 & & 459 & 325 & & \\
\hline$A B S \_A A$ & 0.072 & 0.057 & $(0.015)^{* * *}$ & 0.066 & 0.056 & $(0.010)^{*}$ & 0.001 \\
\hline$N$ & 735 & 686 & & 643 & 594 & & \\
\hline$A B S \_A W C A$ & 0.065 & 0.052 & $(0.013)^{* *}$ & 0.059 & 0.048 & $(0.011)^{* *}$ & 0.004 \\
\hline$N$ & 735 & 686 & & 643 & 594 & & \\
\hline$A B S \_P M A A$ & 0.083 & 0.068 & $(0.015)^{* * *}$ & 0.078 & 0.063 & $(0.015)^{* * *}$ & 0.005 \\
\hline$N$ & 735 & 686 & & 643 & 594 & & \\
\hline ABS_PMAWCA & 0.069 & 0.059 & $(0.010)^{*}$ & 0.065 & 0.052 & $(0.013)^{* *}$ & 0.007 \\
\hline$N$ & 735 & 686 & & 643 & 594 & & \\
\hline
\end{tabular}

Table 9 panel A provides the univariate test for the difference between the accrual quality measures in the pre- and post- FIN 46 periods for the FIN 46 firms and the matched pairs. $A B S \_A A$ is the absolute values of abnormal total accruals; $A B S \_A W C A$ is the absolute value of abnormal working capital accruals; $A B S P M A A$ is the absolute values of performance-matched abnormal total accruals; $A B S P M A W C A$ is 
the absolute values of performance-matched working capital accruals; $A B S D D$ is the absolute value of the estimation errors from DD 2002 model; $A B S \_M D D$ is the absolute value of the estimation errors from modified DD 2002 model; STD_DD is the standard deviation of the estimation errors from DD 2002 model; STD_MDD is the standard deviation of the estimation error from modified DD 2002 model. 
Table 9 Panel B: Additional Analysis of H1

- FIN 46 Firms and Matched Pairs

\begin{tabular}{|c|c|c|c|c|c|c|c|c|}
\hline \multirow[b]{2}{*}{ Variable } & \multicolumn{2}{|c|}{$\underline{A B S \quad M D D}$} & \multicolumn{2}{|c|}{$\underline{S T D} M D D$} & \multicolumn{2}{|c|}{$\underline{A B S \quad D D}$} & \multicolumn{2}{|c|}{$\underline{S T D D D}$} \\
\hline & Coefficient & p-value & Coefficient & p-value & $\underline{\text { Coefficient }}$ & p-value & Coefficient & p-value \\
\hline Intercept & 0.017 & 0.014 & 0.020 & 0.020 & 0.014 & 0.112 & 0.005 & 0.658 \\
\hline POST & 0.002 & 0.471 & 0.004 & 0.127 & 0.001 & 0.643 & 0.006 & 0.096 \\
\hline FIN46 & -0.002 & 0.366 & -0.001 & 0.721 & 0.000 & 0.985 & 0.003 & 0.311 \\
\hline POST*FIN46 & 0.008 & 0.015 & 0.008 & 0.029 & 0.006 & 0.165 & 0.006 & 0.195 \\
\hline Leverage & 0.002 & 0.575 & -0.004 & 0.448 & 0.013 & 0.027 & 0.005 & 0.387 \\
\hline SGROWTH & 0.021 & $<0.0001$ & 0.018 & $<0.0001$ & 0.035 & $<0.0001$ & 0.030 & $<0.0001$ \\
\hline SIZE & -0.005 & $<0.0001$ & -0.006 & $<0.0001$ & -0.008 & $<0.0001$ & -0.008 & $<0.0001$ \\
\hline ROA & -0.043 & $<0.0001$ & -0.057 & $<0.0001$ & -0.027 & 0.018 & -0.074 & $<0.0001$ \\
\hline LOG_CYCLE & 0.010 & $<0.0001$ & 0.012 & $<0.0001$ & 0.014 & $<0.0001$ & 0.019 & $<0.0001$ \\
\hline Adj. $\mathbf{R}^{2}$ & $12.82 \%$ & & $14.73 \%$ & & $15.03 \%$ & & $19.40 \%$ & \\
\hline $\mathbf{N}$ & 2296 & & 1462 & & 2296 & & 1462 & \\
\hline
\end{tabular}

Table 9 Panel B provides the regression results of the following model: 


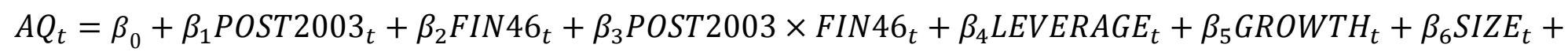

$$
\begin{aligned}
& \beta_{7} R O A_{t}+\beta_{8} O C F_{t}+\beta_{9} O C F 2_{t}+\beta_{10} L O G_{-} C Y C L E_{t}+\varepsilon_{t}
\end{aligned}
$$

$A Q$ here are $A B S \_D D, A B S \_M D D, S T D \_D D$ and $S T D \_M D D$. $A B S \_D D$ is the absolute value of the estimation errors from DD 2002 model; $A B S \_M D D$ is the absolute value of the estimation errors from modified DD 2002 model; $S T D \_D D$ is the standard deviation of the estimation errors from DD 2002 model; STD_MDD is the standard deviation of the estimation error from modified DD 2002 model; POST is an indicator variable for testing years after 2003; FIN46 is an indicator variable for firms affected by FIN 46, that is, firms having VIEs subject to consolidation requirement. These firms chose either consolidated VIEs or keeping VIEs off the financial statement by restructuring or terminating VIEs; SIZE is logarithm of lagged total assets; Leverage is measured as total liability divided by total assets; SGROWTH is measured as the change in sales divided by lagged total assets; $R O A$ is the income before extraordinary items divided by lagged total assets; $L O G \_C Y C L E$ is logarithm of operating cycle, which is measured as the sum of average days of accounts receivable and average days of inventory. 
Table 10: Additional Analysis of $\mathbf{H 2}$ -Group 1 and Matched Pairs

\begin{tabular}{|c|c|c|c|c|c|c|c|c|}
\hline \multirow[b]{2}{*}{ Variable } & \multicolumn{2}{|c|}{$\underline{A B S \quad M D D}$} & \multicolumn{2}{|c|}{ STD MDD } & \multicolumn{2}{|c|}{$\underline{A B S \quad D D}$} & \multicolumn{2}{|c|}{$\underline{S T D \quad D D}$} \\
\hline & $\underline{\text { Coefficient }}$ & p-value & Coefficient & p-value & $\underline{\text { Coefficient }}$ & p-value & $\underline{\text { Coefficient }}$ & p-value \\
\hline Intercept & 0.019 & 0.010 & 0.020 & 0.039 & 0.024 & 0.013 & 0.009 & 0.452 \\
\hline POST & 0.002 & 0.424 & 0.007 & 0.043 & 0.004 & 0.336 & 0.009 & 0.022 \\
\hline FIN46 & -0.002 & 0.256 & -0.002 & 0.499 & 0.000 & 0.916 & 0.002 & 0.492 \\
\hline POST*FIN46 & 0.010 & 0.010 & 0.010 & 0.027 & 0.007 & 0.148 & 0.007 & 0.220 \\
\hline Leverage & 0.003 & 0.602 & 0.003 & 0.680 & 0.008 & 0.233 & 0.010 & 0.194 \\
\hline SGROWTH & 0.017 & $<0.0001$ & 0.013 & 0.000 & 0.026 & $<0.0001$ & 0.016 & 0.000 \\
\hline SIZE & -0.006 & $<0.0001$ & -0.007 & $<0.0001$ & -0.008 & $<0.0001$ & -0.010 & $<0.0001$ \\
\hline ROA & -0.034 & $<0.0001$ & -0.025 & 0.068 & -0.033 & 0.010 & -0.021 & 0.238 \\
\hline LOG_CYCLE & 0.013 & $<0.0001$ & 0.013 & $<0.0001$ & 0.014 & $<0.0001$ & 0.021 & $<0.0001$ \\
\hline Adj. $R^{2}$ & $13.91 \%$ & & $15.63 \%$ & & $15.05 \%$ & & $19.67 \%$ & \\
\hline $\mathbf{N}$ & 1798 & & 1158 & & 1798 & & 1158 & \\
\hline
\end{tabular}

Table 10 provides the regression results of the following model: 


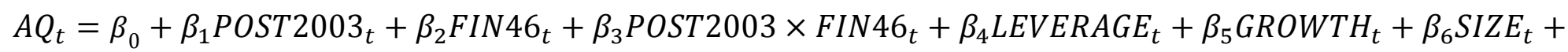

$$
\begin{aligned}
& \beta_{7} R O A_{t}+\beta_{8} O C F_{t}+\beta_{9} O C F 2_{t}+\beta_{10} L O G_{-} C Y C L E_{t}+\varepsilon_{t}
\end{aligned}
$$

$A Q$ here are $A B S \_D D, A B S \_M D D, S T D \_D D$ and $S T D \_M D D$. The test sample includes firms consolidating VIEs (group 1), the control sample includes group 1 firms' matched pairs. $A B S_{-} D D$ is the absolute value of the estimation errors from DD 2002 model; $A B S_{-} M D D$ is the absolute value of the estimation errors from modified DD 2002 model; STD DD is the standard deviation of the estimation errors from DD 2002 model; STD_MDD is the standard deviation of the estimation error from modified DD 2002 model; POST is an indicator variable for testing years after 2003; FIN46 is an indicator variable for firms consolidating VIEs (group 1); SIZE is logarithm of lagged total assets; Leverage is measured as total liability divided by total assets; SGROWTH is measured as the change in sales divided by lagged total assets; $R O A$ is the income before extraordinary items divided by lagged total assets; LOG_CYCLE is logarithm of operating cycle, which is measured as the sum of average days of accounts receivable and average days of inventory. 
Table 11: Additional Analysis of $\mathbf{H} 2$

- Group 1 and Group 2

\begin{tabular}{|c|c|c|c|c|c|c|c|c|}
\hline \multirow[b]{2}{*}{ Variable } & \multicolumn{2}{|c|}{$\underline{A B S \quad D D}$} & \multicolumn{2}{|c|}{$A B S M D D$} & \multicolumn{2}{|c|}{$\underline{S T D} D D$} & \multicolumn{2}{|c|}{$\underline{S T D M D D}$} \\
\hline & Coefficient & p-value & Coefficient & p-value & Coefficient & p-value & Coefficient & p-value \\
\hline Intercept & 0.047 & 0.007 & 0.030 & 0.049 & 0.016 & 0.364 & 0.025 & 0.047 \\
\hline POST & -0.003 & 0.459 & 0.001 & 0.759 & -0.017 & $<0.0001$ & -0.007 & 0.029 \\
\hline FIN46_CON & 0.004 & 0.607 & -0.001 & 0.857 & -0.002 & 0.808 & -0.004 & 0.498 \\
\hline POST*FIN46_CON & 0.014 & 0.176 & 0.018 & 0.051 & 0.022 & 0.031 & 0.014 & 0.055 \\
\hline Leverage & 0.038 & $<0.0001$ & 0.036 & $<0.0001$ & 0.024 & 0.001 & 0.020 & 0.000 \\
\hline SGROWTH & 0.025 & $<0.0001$ & 0.025 & $<0.0001$ & 0.027 & $<0.0001$ & 0.021 & $<0.0001$ \\
\hline SIZE & -0.011 & $<0.0001$ & -0.010 & $<0.0001$ & -0.013 & $<0.0001$ & -0.010 & $<0.0001$ \\
\hline$R O A$ & -0.045 & $<0.0001$ & -0.050 & $<0.0001$ & -0.024 & 0.006 & -0.022 & 0.000 \\
\hline LOG_CYCLE & 0.010 & 0.001 & 0.010 & 0.000 & 0.025 & $<0.0001$ & 0.016 & $<0.0001$ \\
\hline $\operatorname{Adj.} R^{2}$ & $18.47 \%$ & & $22.04 \%$ & & $22.40 \%$ & & $25.00 \%$ & \\
\hline $\mathbf{N}$ & 1557 & & 1557 & & 1321 & & 1320 & \\
\hline
\end{tabular}

Table 11 provides the regression results of the following model:

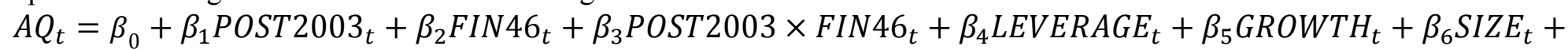

$$
\beta_{7} R O A_{t}+\beta_{8} O C F_{t}+\beta_{9} O C F 2_{t}+\beta_{10} L O G_{-} C Y C L E_{t}+\varepsilon_{t}
$$


$A Q$ here are $A B S \_D D, A B S \_M D D, S T D \_D D$ and $S T D \_M D D$. The test sample includes firms consolidating VIEs (group 1), the control sample includes firms terminating or restructuring VIEs (group 2). $A B S \_M D D$ is the absolute value of the estimation errors from modified DD 2002 model; STD DD is the standard deviation of the estimation errors from DD 2002 model; STD MDD is the standard deviation of the estimation error from modified DD 2002 model; POST is an indicator variable for testing years after 2003; FIN46 is an indicator variable for firms consolidating VIEs (group 1); SIZE is logarithm of lagged total assets; Leverage is measured as total liability divided by total assets; $S G R O W T H$ is measured as the change in sales divided by lagged total assets; $R O A$ is the income before extraordinary items divided by lagged total assets; $L O G \_C Y C L E$ is logarithm of operating cycle, which is measured as the sum of average days of accounts receivable and average days of inventory. 


\section{Table 12: Additional Analysis for Group 1 and 2}

- AA and AWCA

\begin{tabular}{|c|c|c|c|c|}
\hline \multirow[b]{2}{*}{ Variable } & \multicolumn{2}{|c|}{$\underline{A A}$} & \multicolumn{2}{|c|}{$\underline{A W C A}$} \\
\hline & Coefficient & p-value & Coefficient & p-value \\
\hline Intercept & 0.079 & $<0.0001$ & 0.079 & $<0.0001$ \\
\hline POST & -0.018 & 0.000 & -0.011 & 0.013 \\
\hline FIN46_CON & -0.009 & 0.048 & -0.001 & 0.862 \\
\hline POST*FIN46_CON & 0.012 & 0.049 & 0.010 & 0.072 \\
\hline Leverage & 0.018 & 0.030 & -0.012 & 0.101 \\
\hline SGROWTH & -0.030 & $<0.0001$ & -0.015 & $<0.0001$ \\
\hline SIZE & -0.004 & $<0.0001$ & -0.003 & $<0.0001$ \\
\hline ROA & 0.800 & $<0.0001$ & 0.696 & $<0.0001$ \\
\hline OCF & -0.588 & $<0.0001$ & -0.608 & $<0.0001$ \\
\hline LOG_CYCLE & -0.003 & 0.168 & -0.002 & 0.177 \\
\hline Adj. $\mathbf{R}^{2}$ & $62.43 \%$ & & $64.14 \%$ & \\
\hline $\mathbf{N}$ & 1174 & & 1174 & \\
\hline
\end{tabular}

Table 12 provides the regression results of the following model:

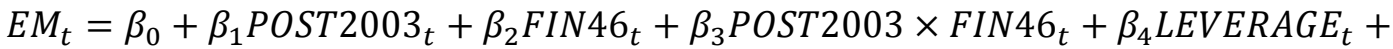

$$
\begin{aligned}
& \beta_{5} \text { GROWTH }_{t}+\beta_{6} \text { SIZE }_{t}+\beta_{7} \text { ROA }_{t}+\beta_{8} O C F_{t}+\beta_{9} O C F 2_{t}+\beta_{10} L O G_{-} C Y C L E_{t}+\varepsilon_{t}
\end{aligned}
$$

$E M$ is earnings management measured by $A A$ and $A W C A$. The test sample includes firms consolidating VIEs (group 1), the control sample includes firms terminating or restructuring VIEs (group 2). $A A$ is abnormal total accruals; $A W C A$ is abnormal working capital accruals; $P O S T$ is an indicator variable for testing years after 2003; FIN46_CON is an indicator variable for firms consolidating VIEs (group 1); SIZE is logarithm of lagged total assets; Leverage is measured as total liability divided by total assets; $O C F$ is measured as operating cash flow divided by lagged total assets; SGROWTH is measured as the change in sales divided by lagged total assets; ROA is the income before extraordinary items divided by lagged total assets; $L O G_{-} C Y C L E$ is logarithm of operating cycle, which is measured as the sum of average days of accounts receivable and average days of inventory. 


\section{Table 13: Additional Analysis for Group 1 and 2 \\ - PMAA and PMAWCA}

\begin{tabular}{|c|c|c|c|c|}
\hline \multirow[b]{2}{*}{ Variable } & \multicolumn{2}{|c|}{$\underline{P M A A}$} & \multicolumn{2}{|c|}{ PMAWCA } \\
\hline & Coefficient & p-value & Coefficient & p-value \\
\hline Intercept & 0.118 & $<0.0001$ & 0.103 & $<0.0001$ \\
\hline POST & -0.018 & 0.000 & -0.011 & 0.013 \\
\hline FIN46_CON & -0.009 & 0.048 & -0.001 & 0.862 \\
\hline POST*FIN46_CON & 0.012 & 0.049 & 0.010 & 0.072 \\
\hline Leverage & 0.018 & 0.030 & -0.012 & 0.101 \\
\hline SGROWTH & -0.030 & $<0.0001$ & -0.015 & $<0.0001$ \\
\hline SIZE & -0.004 & $<0.0001$ & -0.003 & $<0.0001$ \\
\hline ROA & 0.800 & $<0.0001$ & 0.696 & $<0.0001$ \\
\hline OCF & -0.588 & $<0.0001$ & -0.608 & $<0.0001$ \\
\hline LOG_CYCLE & -0.003 & 0.168 & -0.002 & 0.177 \\
\hline $\operatorname{Adj} . \mathrm{R}^{2}$ & $62.43 \%$ & & $64.14 \%$ & \\
\hline $\mathbf{N}$ & 1174 & & 1174 & \\
\hline
\end{tabular}

Table 13 provides the regression results of the following model:

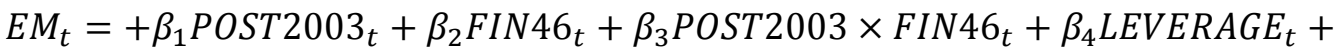
$\beta_{5}$ GROWTH $_{t}+\beta_{6}$ SIZE $_{t}+\beta_{7} R O A_{t}+\beta_{8} O C F_{t}+\beta_{9} O C F 2_{t}+\beta_{10} L O G_{-} C Y C L E_{t}+\varepsilon_{t}$

$E M$ is earnings management measured by $P M A A$ and $P M A W C A$. The test sample includes firms consolidating VIEs (group 1), the control sample includes firms terminating or restructuring VIEs (group 2). PMAA is performance-matched abnormal total accruals; PMAWCA is the absolute values of performance-matched working capital accruals; $P O S T$ is an indicator variable for testing years after 2003; FIN46_CON is an indicator variable for firms consolidating VIEs (group 1); SIZE is logarithm of lagged total assets; Leverage is measured as total liability divided by total assets; $O C F$ is measured as operating cash flow divided by lagged total assets; SGROWTH is measured as the change in sales divided by lagged total assets; $R O A$ is the income before extraordinary items divided by lagged total assets; $L O G \_C Y C L E$ is logarithm of operating cycle, which is measured as the sum of average days of accounts receivable and average days of inventory. 
TABLE 14: Sample Deviation

\section{Group 1:}

Number of firms found in 10-K wizard

Number of non-financial firms that have non-missing values

Number of observations for non-financial firms for year 1988-2012

1791

Number of observations for non-financial firms for year 1998 - 2007

\section{Group}

2:

Number of firms found in $10-\mathrm{K}$ wizard

Number of non-financial firms that have non-missing values

Number of observations for non-financial firms for year 1988-2012

Number of observations for non-financial firms for year 1998- 2007

\section{Group 3:}

Number of firms found in 10-K wizard

Number of non-financial firms that have non-missing values

Number of observations for non-financial firms for year 1988-2012

Number of observations for non-financial firms for year $1998-2007$

Note: this table provides the sample deviation for the tests on investment efficiency measured by the deviation from expected investment. Group 1 is defined for firms consolidating VIEs. Group 2 is defined for firms restructuring or terminating VIES to avoid consolidating. Group 3 is defined for firms reporting no (material) impact from FIN 46. 260 firms are found for group 1 through $10 \mathrm{~K}$ wizard. After deleting firms with missing values to estimating variables and firms in financial industries, 135 firms left. There are 1791 firm-year observations from 1988 to 2012. There are 784 firm-year observations in the final sample for group 1 from 1998 to 2007. Using similar filtering process, group 2, 3 have 361 and 4728 firm-year observations respectively from $1998-2007$. 
TABLE 15: Descriptive Statistics

\begin{tabular}{lccccc}
\hline FIN 46 firms & Mean & Q1 & Median & Q3 & SD \\
\cline { 2 - 5 } INVEFF1 & 0.116 & 0.032 & 0.071 & 0.128 & 0.187 \\
INVEFF2 & 0.099 & 0.024 & 0.051 & 0.109 & 0.187 \\
INVEFF3 & 0.119 & 0.032 & 0.075 & 0.138 & 0.195 \\
ROA & -0.009 & 0.004 & 0.032 & 0.060 & 0.210 \\
SIZE & 7.109 & 5.897 & 7.246 & 8.517 & 1.974 \\
MB & 1.380 & 0.427 & 0.775 & 1.485 & 2.129 \\
Tangibility & 0.331 & 0.103 & 0.259 & 0.510 & 0.260 \\
Kstructure & 0.247 & 0.038 & 0.176 & 0.402 & 0.240 \\
CFOsale & -0.275 & 0.025 & 0.088 & 0.174 & 3.773 \\
Slack & 1.811 & 0.031 & 0.155 & 0.792 & 6.366 \\
Dividend & 0.527 & 0.000 & 1.000 & 1.000 & 0.500 \\
OPCycle & 136.694 & 58.910 & 91.839 & 152.063 & 154.597 \\
Loss & 0.231 & 0.000 & 0.000 & 0.000 & 0.422 \\
N & 893 & & & &
\end{tabular}

No Impact Firms

\begin{tabular}{lccccc} 
INVEFF1 & 0.193 & 0.048 & 0.112 & 0.209 & 0.299 \\
INVEFF2 & 0.156 & 0.038 & 0.085 & 0.167 & 0.252 \\
INVEFF3 & 0.174 & 0.046 & 0.107 & 0.197 & 0.267 \\
ROA & -0.147 & -0.161 & 0.015 & 0.068 & 0.471 \\
SIZE & 4.308 & 3.122 & 4.337 & 5.546 & 2.099 \\
MB & 1.813 & 0.482 & 0.902 & 1.768 & 3.033 \\
Tangibility & 0.352 & 0.096 & 0.284 & 0.559 & 0.290 \\
Kstructure & 0.159 & 0.000 & 0.059 & 0.253 & 0.213 \\
CFOsale & -1.428 & -0.083 & 0.053 & 0.170 & 7.648 \\
Slack & 2.347 & 0.009 & 0.149 & 1.052 & 7.751 \\
Dividend & 0.275 & 0.000 & 0.000 & 1.000 & 0.447 \\
OPCycle & 169.849 & 80.872 & 123.771 & 193.050 & 177.712 \\
Loss & 0.441 & 0.000 & 0.000 & 1.000 & 0.497 \\
N & 4263 & & & & \\
\hline
\end{tabular}

Note: this table presents the descriptive statistics for FIN 46 firms (group 1 and 2) and no impact firms (group 3). INVEFF 1 is the absolute value of the residuals from equation (8). INVEFF2 is the absolute value of the residuals from equation (9). INVEFF3 is the absolute value of the residuals from equation (10). SIZE is logarithm of lagged total assets; Leverage is measured as total liability divided by total assets; $R O A$ is the income before extraordinary items divided by 
lagged total assets; $M B$ is the market value of equity divided by total assets; Tangibility is measured as property, plant and equipment divided by total assets; $K$-structure is measured as long-term debt divided by the sum of long-term debt and the market value of equity; CFOsale is operating cash flow divided by sales; Slack is cash divided by property, plant and equipment; Dividend is an indicator variable for firm paid a dividend; OPCycle is operating cycle measured as the sum of 365 divided by inventory turnover and 365 divided by receivable turnover. 
TABLE 16: Multivariate Regression Results for Investment-Cash Flow Sensitivity

\begin{tabular}{|c|c|c|}
\hline \multirow[b]{2}{*}{ Variable } & \multicolumn{2}{|c|}{ Investment } \\
\hline & Coefficient & p-value \\
\hline Intercept & 0.166 & $<0.0001$ \\
\hline POST & -0.042 & $<0.0001$ \\
\hline FIN46 & -0.024 & 0.105 \\
\hline$O C F$ & -0.177 & $<0.0001$ \\
\hline FIN46*OCF & -0.299 & $<0.0001$ \\
\hline POST ${ }^{*} O C F$ & 0.156 & $<0.0001$ \\
\hline POST ${ }^{*} F I N 46 * O C F$ & 0.591 & $<0.0001$ \\
\hline SIZE & 0.001 & 0.762 \\
\hline$M B$ & 0.027 & $<0.0001$ \\
\hline Adj. $R^{2}$ & $21.82 \%$ & \\
\hline $\mathbf{N}$ & 4188 & \\
\hline
\end{tabular}

Table 16 provides the regression results of the following model:

$$
\begin{aligned}
& \text { Investment }_{i, t}=b+\eta_{1} \text { POST }+\eta_{2}{\text { FIN } 46+b_{1} O C F_{i, t}+\eta_{3}{\text { FIN } 46 * O C F_{i, t}}^{*} \eta_{3} \text { POST }}_{*} \text { OCF }_{i, t} \\
& +\eta 3 \text { POST*FIN46* OCF } F_{i, t}+b_{2} \text { MB }_{i, t}+b_{3} \text { Size }_{i, t}+\varepsilon_{i, t,}
\end{aligned}
$$

The test sample includes firms having VIEs affected by FIN 46 (group 1 and 2). The control sample includes firms reporting no (material) impact from FIN 46 (group 3).

The dependent variable is Investment measured as the sum of research and development expenditure, capital expenditure, and acquisition expenditure less cash receipts from sale of property, plant, and equipment scaled by lagged total assets. $O C F$ is operating cash flow scaled by lagged total assets. $M B$ is market value of equity divided by total assets, which is a proxy for Tobin's Q. 
TABLE 17 Regression Results for H3

Investment-Cash Flow Sensitivity - FIN 46 Firms and Matched Pairs

\begin{tabular}{|c|c|c|}
\hline \multirow[b]{2}{*}{ Variable } & \multicolumn{2}{|c|}{ Investment } \\
\hline & Coefficient & p-value \\
\hline Intercept & 0.212 & $<0.0001$ \\
\hline POST & -0.051 & $<0.0001$ \\
\hline FIN46 & -0.010 & 0.421 \\
\hline OCF & -0.406 & $<0.0001$ \\
\hline FIN46*OCF & -0.056 & 0.247 \\
\hline $\mathrm{POST}^{*} \mathrm{OCF}$ & 0.351 & $<0.0001$ \\
\hline POST $*$ FIN46*OCF & 0.400 & $<0.0001$ \\
\hline SIZE & -0.010 & 0.001 \\
\hline$M B$ & 0.044 & $<0.0001$ \\
\hline $\operatorname{Adj.} \mathbf{R}^{2}$ & $27.86 \%$ & \\
\hline $\mathbf{N}$ & 1456 & \\
\hline
\end{tabular}

Table 17 provides the regression results of the following model:

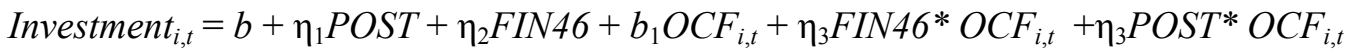

$$
\begin{aligned}
& +\eta 3 \text { POST }^{*} \text { FIN } 46 * ~^{*} \mathrm{OCF}_{i, t}+b_{2} \mathrm{MB}_{i, t}+b_{3} \text { Size }_{i, t}+\varepsilon_{i, t},
\end{aligned}
$$

The test sample includes firms having VIEs affected by FIN 46 (group 1 and 2). The control sample includes the matched pairs of FIN 46 firms. The dependent variable is Investment measured as the sum of research and development expenditure, capital expenditure, and acquisition expenditure less cash receipts from sale of property, plant, and equipment scaled by lagged total assets. $O C F$ is operating cash flow scaled by lagged total assets. $M B$ is market value of equity divided by total assets, which is a proxy for Tobin's Q. 
TABLE 18:

Deviation from Expected Investment Analyses: FIN 46 Firms and Matched Pairs

\begin{tabular}{|c|c|c|c|c|c|c|}
\hline \multirow[b]{2}{*}{ Variable } & \multicolumn{2}{|c|}{$\begin{array}{c}\text { Model } 1 \\
\text { INVEFF1 } \\
\end{array}$} & \multicolumn{2}{|c|}{$\begin{array}{c}\text { Model } 2 \\
\text { INVEFF2 } \\
\end{array}$} & \multicolumn{2}{|c|}{$\begin{array}{c}\text { Model } 3 \\
\text { INVEFF3 } \\
\end{array}$} \\
\hline & $\underline{\text { Coefficient }}$ & p-value & Coefficient & p-value & Coefficient & p-value \\
\hline Intercept & 0.082 & 0.000 & 0.089 & $<0.0001$ & 0.072 & 0.001 \\
\hline POST & 0.020 & 0.114 & 0.032 & 0.010 & 0.029 & 0.019 \\
\hline FIN46 & 0.026 & 0.024 & 0.030 & 0.006 & 0.027 & 0.014 \\
\hline POST*FIN46 & -0.029 & 0.096 & -0.039 & 0.017 & -0.031 & 0.052 \\
\hline ROA & -0.214 & $<0.0001$ & -0.218 & $<0.0001$ & -0.239 & $<0.0001$ \\
\hline SIZE & 0.000 & 0.918 & -0.005 & 0.036 & 0.000 & 0.975 \\
\hline MB & 0.014 & $<0.0001$ & 0.015 & $<0.0001$ & 0.015 & $<0.0001$ \\
\hline Tangibility & 0.023 & 0.266 & 0.016 & 0.421 & 0.024 & 0.218 \\
\hline Kstructure & -0.014 & 0.561 & 0.008 & 0.730 & -0.014 & 0.546 \\
\hline CFOsale & -0.002 & 0.837 & 0.025 & 0.023 & 0.019 & 0.077 \\
\hline Slack & -0.002 & 0.153 & -0.001 & 0.561 & 0.000 & 0.950 \\
\hline
\end{tabular}




\begin{tabular}{|c|c|c|c|c|c|c|}
\hline Dividend & -0.006 & 0.497 & -0.001 & 0.914 & -0.004 & 0.648 \\
\hline OPCYCLE & 0.000 & 0.023 & 0.000 & 0.052 & 0.000 & 0.664 \\
\hline LOSS & -0.011 & 0.432 & -0.004 & 0.794 & -0.021 & 0.129 \\
\hline Adj. $R^{2}$ & $6.52 \%$ & & $7.15 \%$ & & $6.37 \%$ & \\
\hline $\mathbf{N}$ & 970 & & 884 & & 884 & \\
\hline
\end{tabular}

Table 18 presents the regression results of the following models:

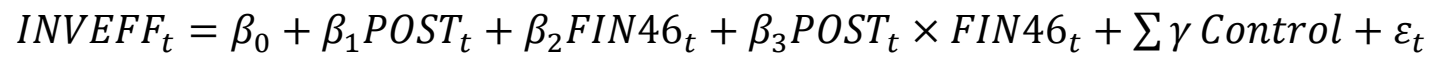

The test sample includes firms affected by FIN 46. The control sample includes the matched pairs of FIN 46 firms. The dependent variables INVEFF1, INVEFF2, INVEFF3 are the absolute values of the residuals from equation (8), (9) and (10) respectively.

$$
\begin{aligned}
& \text { Investment }_{\mathrm{i}, \mathrm{t}}=\lambda_{0}+\lambda_{1} N E G_{i, t-1}+\lambda_{2} \text { SalesGrowth }_{\mathrm{i}, \mathrm{t}-1}+\lambda_{3} N E G^{*} \text { SalesGrowth }_{\mathrm{i}, \mathrm{t}-1}+\xi_{\mathrm{i}, \mathrm{t}} \\
& \text { Investment }_{i, t}=\lambda_{0}+\lambda_{1} N E G_{t-1}+\lambda_{2} \text { SalesGrowth }_{i, t-1}+\lambda_{3} N E G^{*} \text { SalesGrowth }_{i, t-1}+\lambda_{4} \text { Investment }_{i, t-1}+\xi_{i, t+1} \\
& \text { Investment }_{i, t}=\lambda_{0}+\lambda_{1} N E G_{t-1}+\lambda_{2} \text { AssetGrowth }_{i, t-1}+\lambda_{3} N E G^{*} \text { AssetGrowth }_{i, t-1}+\xi_{i, t}
\end{aligned}
$$

FIN46 is an indicator variable, 1 for firms with VIEs and affected by FIN 46, 0 for the matched pairs; POST is an indicator variable for testing years after 2003. The control variables are defined as the following: SIZE is logarithm of lagged total assets; Leverage is measured as total liability divided by total assets; $R O A$ is the income before extraordinary items divided by lagged total assets; $M B$ is the market value of equity divided by total assets; Tangibility is measured as property, plant and equipment divided by total assets; K-structure is measured as long-term debt divided by the sum of long-term debt and the market value of equity; CFOsale is operating cash flow divided by sales; Slack is cash divided by property, plant and equipment; Dividend is an indicator variable for firm paid a dividend; OPCycle is operating cycle measured as the sum of 365 divided by inventory turnover and 365 divided by receivable turnover. 
Table 19: Additional Analysis of $\mathbf{H 3}$

FIN 46 Firms and Matched Pairs

\begin{tabular}{|c|c|c|c|c|c|c|}
\hline \multirow[b]{2}{*}{ Variable } & \multicolumn{2}{|c|}{$\begin{array}{c}\text { Alternative Model } 1 \\
\text { Investment }\end{array}$} & \multicolumn{2}{|c|}{$\begin{array}{c}\text { Alternative Model } 2 \\
\text { Investment }\end{array}$} & \multicolumn{2}{|c|}{$\begin{array}{c}\text { Alternative Model } 3 \\
\text { Investment }\end{array}$} \\
\hline & Coefficient & p-value & Coefficient & p-value & Coefficient & p-value \\
\hline Intercept & 0.064 & 0.047 & 0.057 & 0.082 & 0.066 & 0.098 \\
\hline POST & 0.036 & 0.056 & 0.046 & 0.015 & 0.044 & 0.046 \\
\hline FIN46 & 0.027 & 0.102 & 0.034 & 0.043 & 0.055 & 0.004 \\
\hline POST*FIN46 & -0.044 & 0.071 & -0.056 & 0.024 & -0.076 & 0.008 \\
\hline ROA & -0.345 & $<0.0001$ & -0.364 & $<0.0001$ & -0.520 & $<0.0001$ \\
\hline SIZE & -0.001 & 0.896 & -0.002 & 0.636 & 0.001 & 0.846 \\
\hline МB & 0.033 & $<0.0001$ & 0.027 & $<0.0001$ & 0.044 & $<0.0001$ \\
\hline Tangibility & 0.117 & 0.000 & 0.102 & 0.001 & 0.106 & 0.003 \\
\hline Kstructure & -0.026 & 0.438 & -0.034 & 0.337 & -0.034 & 0.401 \\
\hline CFOsale & -0.003 & 0.837 & 0.018 & 0.303 & 0.048 & 0.017 \\
\hline Slack & -0.006 & 0.001 & -0.006 & 0.005 & -0.005 & 0.034 \\
\hline
\end{tabular}




\begin{tabular}{|c|c|c|c|c|c|c|}
\hline Dividend & -0.024 & 0.070 & -0.016 & 0.241 & -0.005 & 0.766 \\
\hline OPCYCLE & 0.000 & 0.066 & 0.000 & 0.144 & 0.000 & 0.139 \\
\hline LOSS & -0.021 & 0.327 & -0.030 & 0.164 & -0.019 & 0.449 \\
\hline$N E G$ & -0.015 & 0.402 & -0.025 & 0.172 & -0.078 & 0.000 \\
\hline RevGrowth & 0.172 & $<0.0001$ & 0.154 & $<0.0001$ & & \\
\hline NEG*RevGrowth & -0.152 & 0.043 & -0.204 & 0.012 & & \\
\hline Lag_Invest & & & 0.138 & $<0.0001$ & & \\
\hline AssetGrowth & & & & & 0.418 & $<0.0001$ \\
\hline NEG*AssetGrowth & & & & & -0.026 & 0.779 \\
\hline Adj. $R^{2}$ & $43.67 \%$ & & $39.59 \%$ & & $18.76 \%$ & \\
\hline $\mathbf{N}$ & 970 & & 884 & & 884 & \\
\hline \multicolumn{7}{|c|}{$\begin{array}{l}\text { Table } 19 \text { presents the regression results of the following models: } \\
\begin{aligned} \text { Investment }_{i, t}= & \lambda_{0}+\beta_{1} \text { POST }_{t}+\beta_{2} \text { FIN }_{4} 6_{t}+\beta_{3} \text { POST }_{t} \times \text { FIN } 6_{t}+\lambda_{1} N E G_{t-1}+\lambda_{2} \text { SalesGrowth }_{i, t-1} \\
& +\lambda_{3} N E G^{*} \text { SalesGrowt }_{i, t-1}+\sum \gamma \text { Control }+\xi_{i, t}\end{aligned}\end{array}$} \\
\hline \multicolumn{7}{|c|}{ 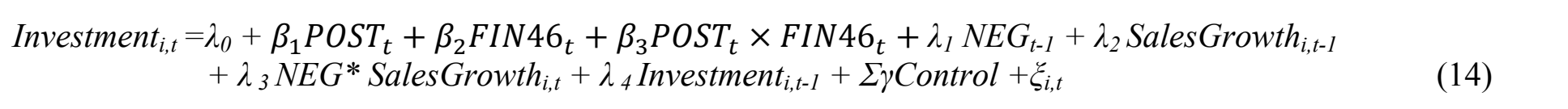 } \\
\hline \multicolumn{6}{|c|}{ 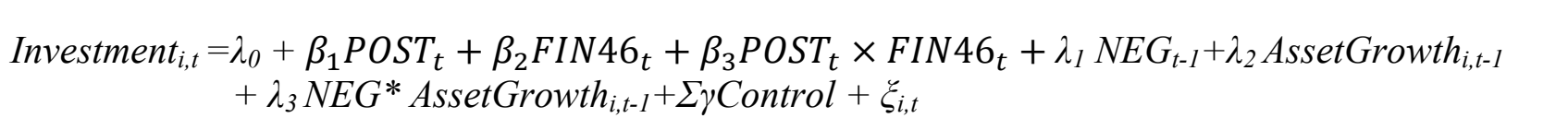 } & (15) \\
\hline
\end{tabular}


The test sample includes firms affected by FIN 46. The control sample includes the matched pairs of FIN 46 firms. FIN46 is an indicator variable, 1 for firms with VIEs and affected by FIN 46, 0 for the matched pairs; POST is an indicator variable for testing years after 2003. The dependent variable Investment is measured as the sum of research and development expenditure, capital expenditure, and acquisition expenditure less cash receipts from sale of property, plant, and equipment scaled by lagged total assets. FIN46 is an indicator variable for firms affected by FIN46; POST is an indicator variable for testing years after 2003; SIZE is logarithm of lagged total assets; Leverage is measured as total liability divided by total assets; $R O A$ is the income before extraordinary items divided by lagged total assets; $M B$ is the market value of equity divided by total assets; Tangibility is measured as property, plant and equipment divided by total assets; K-structure is measured as long-term debt divided by the sum of long-term debt and the market value of equity; CFOsale is operating cash flow divided by sales; Slack is cash divided by property, plant and equipment; Dividend is an indicator variable for firm paid a dividend; OPCycle is operating cycle measured as the sum of 365 divided by inventory turnover and 365 divided by receivable turnover; LOSS is an indicator variable, 1 if net income before extraordinary items is negative and 0 otherwise; RevGrowth is the annual revenue growth rate for firm $\mathrm{i}$ in year t; $N E G$ is an indicator variable for negative revenue growth; Lag_Invest is lagged investment; AssetGrowth is logarithm of total assets in year $t$ divided by total assets in year t-1, following McNichols and Stubben (2008) and Chen et al. (2011). 
TABLE 20 Regression Results for H4

\section{Investment-Cash Flow Sensitivity - Group 1 vs. Group 2}

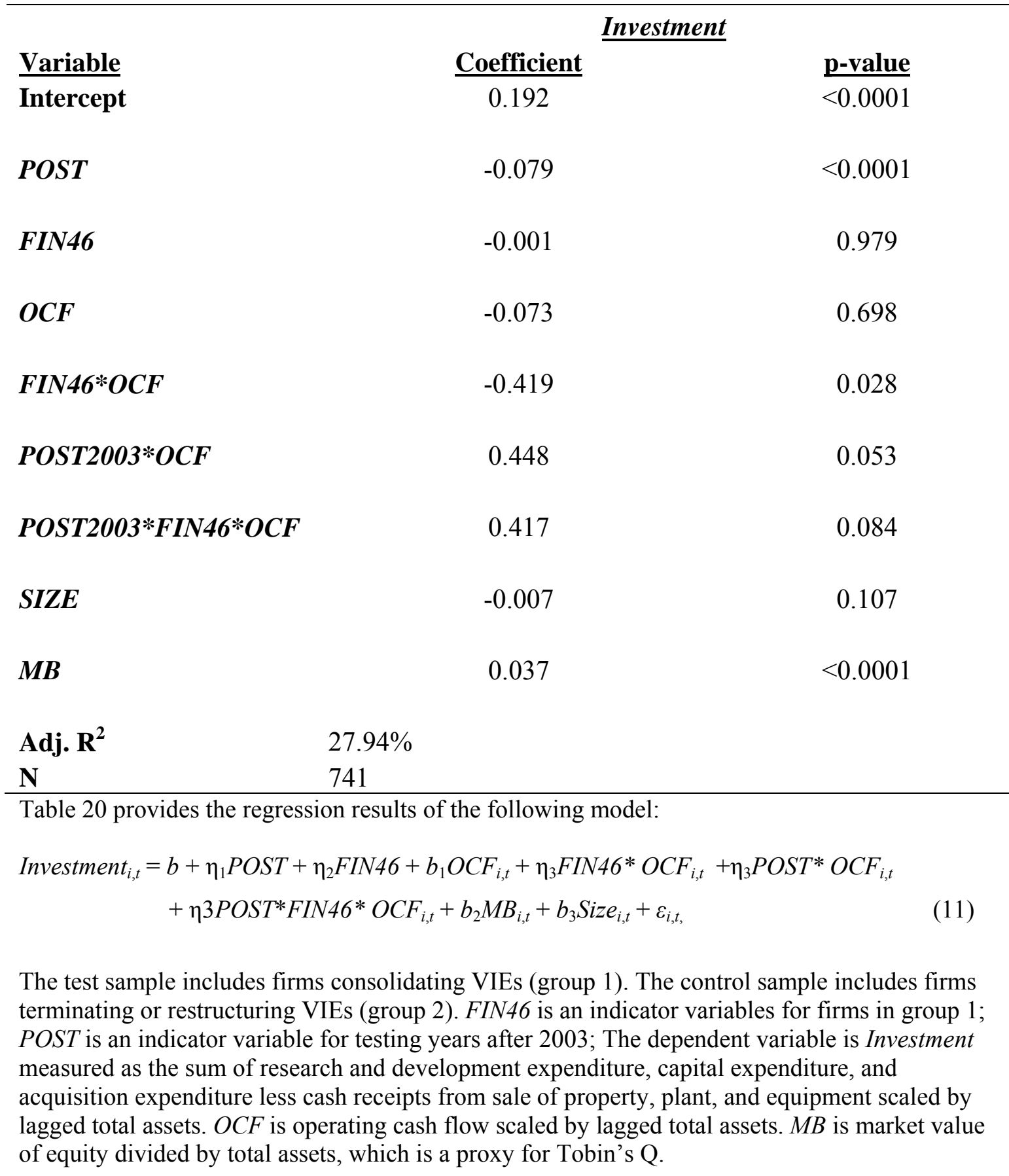


TABLE 21: Investment Efficiency: Firms consolidating VIEs versus Firms Terminating/Restructuring VIE H4 Matched Pairs

\begin{tabular}{|c|c|c|c|c|c|c|}
\hline \multirow[b]{2}{*}{ Variable } & \multicolumn{2}{|c|}{$\begin{array}{l}\text { Alternative Model } 1 \\
\text { Investment }\end{array}$} & \multicolumn{2}{|c|}{$\begin{array}{c}\text { Alternative Model } 2 \\
\text { Investment }\end{array}$} & \multicolumn{2}{|c|}{$\begin{array}{c}\text { Alternative Model } 3 \\
\text { Investment }\end{array}$} \\
\hline & $\underline{\text { Coefficient }}$ & p-value & $\underline{\text { Coefficient }}$ & p-value & Coefficient & p-value \\
\hline Intercept & 0.059 & 0.067 & 0.052 & 0.115 & 0.057 & 0.155 \\
\hline POST & 0.035 & 0.060 & 0.045 & 0.016 & 0.043 & 0.049 \\
\hline ONBOOK & 0.020 & 0.274 & 0.027 & 0.152 & 0.037 & 0.086 \\
\hline OFFBOОК & 0.041 & 0.070 & 0.049 & 0.032 & 0.090 & 0.001 \\
\hline POST ${ }^{*} O N B O O K$ & -0.052 & 0.054 & -0.065 & 0.019 & -0.075 & 0.019 \\
\hline POST*OFFBOOK & -0.031 & 0.358 & -0.040 & 0.226 & -0.080 & 0.039 \\
\hline ROA & -0.345 & $<0.0001$ & -0.363 & $<0.0001$ & -0.518 & $<0.0001$ \\
\hline SIZE & 0.000 & 0.987 & -0.001 & 0.739 & 0.002 & 0.688 \\
\hline MB & 0.033 & $<0.0001$ & 0.028 & $<0.0001$ & 0.044 & $<0.0001$ \\
\hline Tangibility & 0.122 & $<0.0001$ & 0.107 & 0.001 & 0.114 & 0.001 \\
\hline Kstructure & -0.033 & 0.329 & -0.041 & 0.242 & -0.046 & 0.262 \\
\hline
\end{tabular}




\begin{tabular}{|c|c|c|c|c|c|c|}
\hline CFOsale & -0.004 & 0.815 & 0.018 & 0.304 & 0.048 & 0.016 \\
\hline Slack & -0.005 & 0.003 & -0.005 & 0.008 & -0.005 & 0.056 \\
\hline Dividend & -0.024 & 0.070 & -0.015 & 0.243 & -0.005 & 0.741 \\
\hline OPCYCLE & 0.000 & 0.096 & 0.000 & 0.204 & 0.000 & 0.212 \\
\hline LOSS & -0.018 & 0.402 & -0.027 & 0.224 & -0.014 & 0.583 \\
\hline$N E G$ & -0.017 & 0.337 & -0.028 & 0.134 & -0.080 & 0.000 \\
\hline RevGrowth & 0.172 & $<0.0001$ & 0.153 & $<0.0001$ & & \\
\hline NEG*RevGrowth & -0.150 & 0.046 & -0.200 & 0.014 & & \\
\hline Lag_Invest & & & 0.139 & $<0.0001$ & & \\
\hline AssetGrowth & & & & & 0.434 & $<0.0001$ \\
\hline NEG*AssetGrowth & & & & & -0.021 & 0.824 \\
\hline Adj. $\mathbf{R}^{2}$ & $43.76 \%$ & & $39.74 \%$ & & $19.17 \%$ & \\
\hline $\mathbf{N}$ & 970 & & 884 & & 884 & \\
\hline
\end{tabular}

Table 21 presents the regression results of the following models:

Investment $_{i, t}=\lambda_{0}+\beta_{1}$ POST $_{t}+\beta_{2}$ ONBOOK $_{t}+\beta_{3}$ OFFBOOK $_{t}+\beta_{4}$ POST $_{t} \times O_{0 N B O O K_{t}}+\beta_{5}$ POST $_{t} \times$ OFFBOOK $_{t}$ 


$$
\begin{aligned}
& +\lambda_{1} \text { NEG }_{t-1}+\lambda_{2} \text { SalesGrowth }_{i, t-1}+\lambda_{3} \text { NEG }^{*} \text { SalesGrowth }_{i, t-1}+\sum \gamma \text { Control }+\xi_{i, t} \\
\text { Investment }_{i, t}= & \lambda_{0}+\beta_{1} \text { POST }_{t}+\beta_{2} \text { ONBOOK }_{t}+\beta_{3} \text { OFFBOOK }_{t}+\beta_{4} \text { POST }_{t} \times \text { ONBOOK }_{t}+\beta_{5} \text { POST }_{t} \times \text { OFFBOOK }_{t} \\
& +\lambda_{1} \text { NEG }_{t-1}+\lambda_{2} \text { SalesGrowth }_{i, t-1}+\lambda_{3} \text { NEG }^{*} \text { SalesGrowth }_{i, t-1}+\sum \gamma \text { Control }+\lambda_{4} \text { Investment }_{i, t-1}+\xi_{i, t} \\
\text { Investment }_{i, t}= & \lambda_{0}+\beta_{1} \text { POST }_{t}+\beta_{2} \text { ONBOOK }_{t}+\beta_{3} \text { OFFBOOK }_{t}+\beta_{4} \text { POST }_{t} \times \text { ONBOOK }_{t}+\beta_{5} \text { POST }_{t} \times \text { OFFBOOK }_{t} \\
& +\lambda_{1} \text { NEG }_{t-1}+\lambda_{2} \text { AssetGrowt }_{i, t-1}+\lambda_{3} \text { NEG }^{*} \text { AssetGrowth }_{i, t-1}+\sum \gamma \text { Control }+\xi_{i, t}
\end{aligned}
$$

The test sample includes firms affected by FIN 46. The control sample includes the matched pairs of FIN 46 firms. ONBOOK is an indicator variable for firms consolidating VIEs; $O F F B O O K$ is an indicator variable for firms terminating or restructuring VIEs; $P O S T$ is an indicator variable for testing years after 2003. The dependent variable Investment is measured as the sum of research and development expenditure, capital expenditure, and acquisition expenditure less cash receipts from sale of property, plant, and equipment scaled by lagged total assets. FIN46 is an indicator variable for firms affected by FIN46; POST is an indicator variable for testing years after 2003; SIZE is logarithm of lagged total assets; Leverage is measured as total liability divided by total assets; $R O A$ is the income before extraordinary items divided by lagged total assets; $M B$ is the market value of equity divided by total assets; Tangibility is measured as property, plant and equipment divided by total assets; $K$-structure is measured as long-term debt divided by the sum of long-term debt and the market value of equity; $C F O s a l e$ is operating cash flow divided by sales; Slack is cash divided by property, plant and equipment; Dividend is an indicator variable for firm paid a dividend; OPCycle is operating cycle measured as the sum of 365 divided by inventory turnover and 365 divided by receivable turnover; LOSS is an indicator variable, 1 if net income before extraordinary items is negative and 0 otherwise; RevGrowth is the annual revenue growth rate for firm $\mathrm{i}$ in year $\mathrm{t} ; N E G$ is an indicator variable for negative revenue growth; Lag_Invest is lagged investment; AssetGrowth is logarithm of total assets in year t divided by total assets in year t-1, following McNichols and Stubben (2008) and Chen et al. (2011). 
TABLE 22: Additional Analysis of $\mathbf{H 4}$

Group 1 and Matched Pairs

\begin{tabular}{|c|c|c|c|c|c|c|}
\hline \multirow[b]{2}{*}{ Variable } & \multicolumn{2}{|c|}{$\begin{array}{c}\text { Model } 1 \\
\text { INVEFF1 } \\
\end{array}$} & \multicolumn{2}{|c|}{$\begin{array}{c}\text { Model } 2 \\
\text { INVEFF2 } \\
\end{array}$} & \multicolumn{2}{|c|}{$\begin{array}{c}\text { Model } 3 \\
\text { INVEFF3 } \\
\end{array}$} \\
\hline & Coefficient & p-value & Coefficient & p-value & Coefficient & p-value \\
\hline Intercept & 0.122 & $<0.0001$ & 0.110 & $<0.0001$ & 0.094 & $<0.0001$ \\
\hline POST & 0.030 & 0.061 & 0.039 & 0.006 & 0.028 & 0.043 \\
\hline FIN46 & 0.024 & 0.105 & 0.029 & 0.029 & 0.021 & 0.099 \\
\hline POST*FIN46 & -0.036 & 0.097 & -0.046 & 0.017 & -0.028 & 0.137 \\
\hline ROA & -0.156 & 0.002 & -0.166 & 0.000 & -0.185 & $<0.0001$ \\
\hline SIZE & -0.004 & 0.256 & -0.006 & 0.042 & -0.001 & 0.812 \\
\hline MB & 0.010 & 0.002 & 0.007 & 0.053 & 0.009 & 0.007 \\
\hline Tangibility & -0.011 & 0.673 & 0.004 & 0.851 & 0.011 & 0.643 \\
\hline Kstructure & -0.020 & 0.504 & -0.028 & 0.316 & -0.027 & 0.319 \\
\hline CFOsale & 0.010 & 0.490 & 0.020 & 0.118 & 0.012 & 0.352 \\
\hline Slack & -0.002 & 0.123 & -0.001 & 0.515 & 0.000 & 0.936 \\
\hline
\end{tabular}




\begin{tabular}{|c|c|c|c|c|c|c|}
\hline Dividend & -0.003 & 0.822 & 0.002 & 0.872 & -0.007 & 0.516 \\
\hline OPCYCLE & 0.000 & 0.048 & 0.000 & 0.081 & 0.000 & 0.533 \\
\hline LOSS & 0.002 & 0.897 & 0.012 & 0.471 & -0.010 & 0.517 \\
\hline Adj. $\mathbf{R}^{2}$ & $5.13 \%$ & & $7.07 \%$ & & $5.94 \%$ & \\
\hline $\mathbf{N}$ & 662 & & 604 & & 604 & \\
\hline
\end{tabular}

Table 22 presents the regression results of the following models:

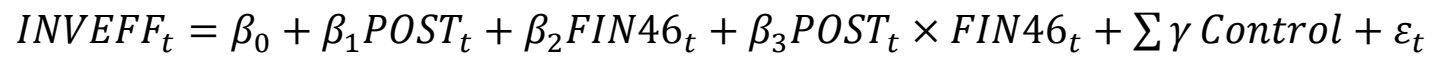

The test sample includes firms affected by FIN 46. The control sample includes the matched pairs of FIN 46 firms. The dependent variables INVEFF1, INVEFF2, INVEFF3 are the absolute values of the residuals from equation (8), (9) and (10) respectively.

$$
\begin{aligned}
& \text { Investment }_{\mathrm{i}, \mathrm{t}}=\lambda_{0}+\lambda_{1} N E G_{i, t-1}+\lambda_{2} \text { SalesGrowth }_{\mathrm{i}, \mathrm{t}-1}+\lambda_{3} N E G^{*} \text { SalesGrowth }_{\mathrm{i}, \mathrm{t}-1}+\xi_{\mathrm{i}, \mathrm{t}} \\
& \text { Investment }_{i, t}=\lambda_{0}+\lambda_{1} N E G_{t-1}+\lambda_{2} \text { SalesGrowth }_{i, t-1}+\lambda_{3} N E G^{*} \text { SalesGrowth }_{i, t-1}+\lambda_{4} \text { Investment }_{i, t-1}+\xi_{i, t+1} \\
& \text { Investment }_{i, t}=\lambda_{0}+\lambda_{1} N E G_{t-1}+\lambda_{2} \text { AssetGrowth }_{i, t-1}+\lambda_{3} N E G^{*} \text { AssetGrowth }_{i, t-1}+\xi_{i, t}
\end{aligned}
$$

FIN46 is an indicator variable, 1 for firms consolidating VIEs (group 1), 0 for group 1 firms' matched pairs; POST is an indicator variable for testing years after 2003. The control variables are defined as the following: SIZE is logarithm of lagged total assets; Leverage is measured as total liability divided by total assets; $R O A$ is the income before extraordinary items divided by lagged total assets; $M B$ is the market value of equity divided by total assets; Tangibility is measured as property, plant and equipment divided by total assets; K-structure is measured as long-term debt divided by the sum of long-term debt and the market value of equity; CFOsale is operating cash flow divided by sales; Slack is cash divided by property, plant and equipment; Dividend is an indicator variable for firm paid a dividend; OPCycle is operating cycle measured as the sum of 365 divided by inventory turnover and 365 divided by receivable turnover. 
TABLE 23: Additional Analysis of $\mathbf{H 4}$

Group 1 and Matched Pairs

\begin{tabular}{|c|c|c|c|c|c|c|}
\hline \multirow[b]{2}{*}{ Variable } & \multicolumn{2}{|c|}{$\begin{array}{c}\text { Alternative Model } 1 \\
\text { Investment }\end{array}$} & \multicolumn{2}{|c|}{$\begin{array}{c}\text { Alternative Model } 2 \\
\text { Investment }\end{array}$} & \multicolumn{2}{|c|}{$\begin{array}{c}\text { Alternative Model } 3 \\
\text { Investment }\end{array}$} \\
\hline & Coefficient & p-value & Coefficient & p-value & Coefficient & p-value \\
\hline Intercept & 0.102 & 0.003 & 0.086 & 0.013 & 0.121 & 0.004 \\
\hline POST & 0.033 & 0.099 & 0.038 & 0.056 & 0.036 & 0.124 \\
\hline FIN46 & 0.024 & 0.188 & 0.027 & 0.132 & 0.038 & 0.076 \\
\hline POST*FIN46 & -0.055 & 0.039 & -0.063 & 0.018 & -0.072 & 0.021 \\
\hline ROA & -0.259 & $<0.0001$ & -0.301 & $<0.0001$ & -0.418 & $<0.0001$ \\
\hline SIZE & -0.003 & 0.445 & -0.001 & 0.710 & -0.003 & 0.578 \\
\hline МB & 0.025 & $<0.0001$ & 0.019 & 0.000 & 0.028 & $<0.0001$ \\
\hline Tangibility & 0.103 & 0.002 & 0.107 & 0.001 & 0.101 & 0.009 \\
\hline Kstructure & -0.047 & 0.205 & -0.066 & 0.081 & -0.084 & 0.059 \\
\hline CFOsale & 0.006 & 0.740 & -0.002 & 0.899 & 0.027 & 0.206 \\
\hline Slack & -0.004 & 0.015 & -0.005 & 0.007 & -0.004 & 0.058 \\
\hline
\end{tabular}




\begin{tabular}{|c|c|c|c|c|c|c|}
\hline Dividend & -0.022 & 0.142 & -0.019 & 0.195 & 0.002 & 0.927 \\
\hline OPCYCLE & 0.000 & 0.114 & 0.000 & 0.239 & 0.000 & 0.487 \\
\hline LOSS & -0.014 & 0.547 & -0.023 & 0.320 & -0.009 & 0.748 \\
\hline$N E G$ & -0.022 & 0.277 & -0.032 & 0.114 & -0.078 & 0.001 \\
\hline RevGrowth & 0.142 & $<0.0001$ & 0.143 & $<0.0001$ & & \\
\hline NEG*RevGrowth & -0.134 & 0.088 & -0.188 & 0.027 & & \\
\hline Lag_Invest & & & 0.082 & 0.004 & & \\
\hline AssetGrowth & & & & & 0.263 & 0.002 \\
\hline NEG*AssetGrowth & & & & & -0.004 & 0.972 \\
\hline Adj. $R^{2}$ & $40.25 \%$ & & $41.62 \%$ & & $18.84 \%$ & \\
\hline $\mathbf{N}$ & 662 & & 604 & & 604 & \\
\hline
\end{tabular}

Table 23 presents the regression results of the following models:

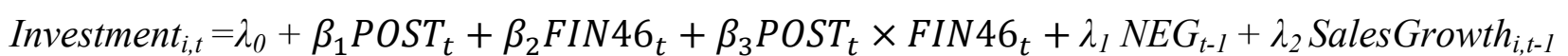

$+\lambda_{3}$ NEG $^{*}$ SalesGrowth $_{i, t-1}+\Sigma \gamma$ Control $+\xi_{i, t}$

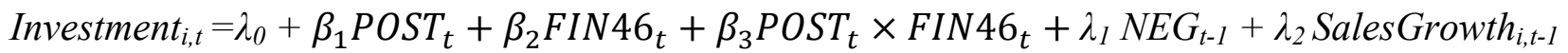

$+\lambda_{3} N E G^{*}$ SalesGrowth $_{i, t}+\lambda_{4}$ Investment $_{i, t-1}+\sum \gamma$ Control $+\xi_{i, t}$ 


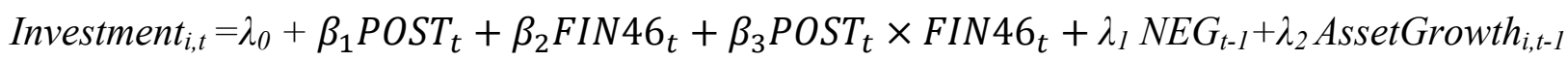

$+\lambda_{3}$ NEG $^{*}$ AssetGrowth $_{i, t-1}+\sum \gamma$ Control $+\xi_{i, t}$

The test sample only includes firms consolidating VIEs (group 1). The control sample includes the matched pairs of group 1 firms. FIN46 is an indicator variable, 1 for firms consolidating VIEs, 0 for the matched pairs; POST is an indicator variable for testing years after 2003.

The dependent variable Investment is measured as the sum of research and development expenditure, capital expenditure, and acquisition expenditure less cash receipts from sale of property, plant, and equipment scaled by lagged total assets. FIN46 is an indicator variable for firms affected by FIN46; POST is an indicator variable for testing years after 2003; SIZE is logarithm of lagged total assets; Leverage is measured as total liability divided by total assets; $R O A$ is the income before extraordinary items divided by lagged total assets; $M B$ is the market value of equity divided by total assets; Tangibility is measured as property, plant and equipment divided by total assets; K-structure is measured as long-term debt divided by the sum of long-term debt and the market value of equity; CFOsale is operating cash flow divided by sales; Slack is cash divided by property, plant and equipment; Dividend is an indicator variable for firm paid a dividend; OPCycle is operating cycle measured as the sum of 365 divided by inventory turnover and 365 divided by receivable turnover; LOSS is an indicator variable, 1 if net income before extraordinary items is negative and 0 otherwise; RevGrowth is the annual revenue growth rate for firm $\mathrm{i}$ in year $\mathrm{t}$; NEG is an indicator variable for negative revenue growth; Lag_Invest is lagged investment; AssetGrowth is logarithm of total assets in year $t$ divided by total assets in year t-1, following McNichols and Stubben (2008) and Chen et al. (2011). 
TABLE 24: Regression Results for $\mathrm{H1}$

Investment-Cash Flow Sensitivity - Constrained and Unconstrained Groups

\begin{tabular}{|c|c|c|c|c|}
\hline \multirow[b]{2}{*}{ Variable } & \multicolumn{2}{|c|}{$\begin{array}{l}\text { Constrained Group } \\
\text { Investment }\end{array}$} & \multicolumn{2}{|c|}{$\begin{array}{l}\text { Unconstrained Group } \\
\text { Investment }\end{array}$} \\
\hline & Coefficient & p-value & Coefficient & p-value \\
\hline$\overline{\text { Intercept }}$ & 0.151 & $<0.0001$ & 0.122 & $<0.0001$ \\
\hline POST & -0.156 & 0.351 & -0.067 & $<0.0001$ \\
\hline FIN46 & -0.017 & 0.450 & -0.024 & 0.174 \\
\hline OCF & -0.138 & $<0.0001$ & -0.277 & $<0.0001$ \\
\hline FIN46_OCF & -0.375 & $<0.0001$ & -0.126 & 0.117 \\
\hline POST_OCF & 0.122 & $<0.0001$ & 0.053 & 0.011 \\
\hline POST*FIN46_OCF & 0.767 & $<0.0001$ & 0.305 & 0.066 \\
\hline SIZE & 0.003 & 0.469 & 0.005 & 0.130 \\
\hline Мв & 0.026 & $<0.0001$ & 0.048 & $<0.0001$ \\
\hline $\begin{array}{l}\text { Adj. } R^{2} \\
N\end{array}$ & $\begin{array}{l}20.03 \% \\
2063\end{array}$ & & $\begin{array}{l}34.10 \% \\
2125\end{array}$ & \\
\hline
\end{tabular}

Table 24 provides the regression results of the following model:

$$
\begin{aligned}
& \text { Investment }_{i, t}=b+\eta_{1} \text { POST }+\eta_{2}{\text { FIN } 46+b_{1} O C F_{i, t}+\eta_{3}{\text { FIN } 46 * O C F_{i, t}}^{*} \eta_{3} \text { POST }}_{*} \text { OCF }_{i, t} \\
& +\eta 3 \text { POST }^{*} \text { FIN } 46 *^{*} \text { OCF }_{i, t}+b_{2} \text { MB }_{i, t}+b_{3} \text { Size }_{i, t}+\varepsilon_{i, t,}
\end{aligned}
$$

The test sample includes firms having VIEs affected by FIN 46 (group 1 and 2). The control sample includes firms reporting no (material) impact from FIN 46 (group 3). The whole sample is partitioned into two groups: constrained group and unconstrained group. I construct an index following Kaplan and Zingales (1997) and Lamont et al. (2001) by using the following model:

KZindex $=-1.002 *$ CashFlow $+0.283 * Q+3.139 *$ Leverage $-39.368 *$ Dividends $1.315^{*}$ CashHoldings

I assign the top (bottom) two quartiles as the financial constrained (unconstrained) group. 
The dependent variable is Investment measured as the sum of research and development expenditure, capital expenditure, and acquisition expenditure less cash receipts from sale of property, plant, and equipment scaled by lagged total assets. $O C F$ is operating cash flow scaled by lagged total assets. $M B$ is market value of equity divided by total assets, which is a proxy for Tobin's Q. 
TABLE 25: Regression Results for $\mathrm{H1}$

Investment-Cash Flow Sensitivity - FIN 46 Firms and Matched Pairs

\begin{tabular}{|c|c|c|c|c|}
\hline \multirow[b]{2}{*}{ Variable } & \multicolumn{2}{|c|}{$\begin{array}{l}\text { Constrained Group } \\
\text { Investment }\end{array}$} & \multicolumn{2}{|c|}{$\begin{array}{c}\text { Unconstrained Group } \\
\text { Investment }\end{array}$} \\
\hline & Coefficient & p-value & Coefficient & p-value \\
\hline$\overline{\text { Intercept }}$ & 0.206 & $<0.0001$ & 0.221 & $<0.0001$ \\
\hline POST & -0.050 & 0.014 & -0.018 & 0.249 \\
\hline FIN46 & 0.008 & 0.706 & -0.027 & 0.079 \\
\hline OCF & -0.410 & $<0.0001$ & -0.399 & $<0.0001$ \\
\hline FIN46_OCF & -0.093 & 0.252 & 0.042 & 0.508 \\
\hline POST_OCF & 0.428 & $<0.0001$ & 0.135 & 0.157 \\
\hline POST*FIN46_OCF & 0.515 & 0.001 & 0.139 & 0.319 \\
\hline SIZE & -0.010 & 0.050 & -0.013 & 0.001 \\
\hline MB & 0.045 & $<0.0001$ & 0.046 & $<0.0001$ \\
\hline Adj. $R^{2}$ & $28.25 \%$ & & $28.87 \%$ & \\
\hline $\mathbf{N}$ & 705 & & 751 & \\
\hline
\end{tabular}

Table 25 provides the regression results of the following model:

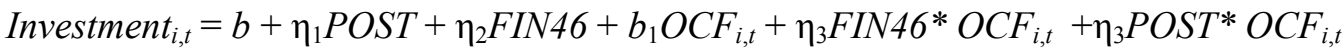

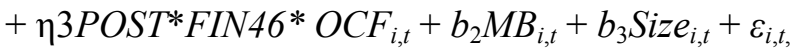

The test sample includes firms having VIEs affected by FIN 46 (group 1 and 2). The control sample includes the matched pairs of FIN 46 firms. The whole sample is partitioned into two groups: constrained group and unconstrained group. I construct an index following Kaplan and Zingales (1997) and Lamont et al. (2001) by using the following model:

KZindex $=-1.002 *$ CashFlow $+0.283 * Q+3.139 *$ Leverage $-39.368 *$ Dividends $1.315^{*}$ CashHoldings

I assign the top (bottom) two quartiles as the financial constrained (unconstrained) group. 
The dependent variable is Investment measured as the sum of research and development expenditure, capital expenditure, and acquisition expenditure less cash receipts from sale of property, plant, and equipment scaled by lagged total assets. $O C F$ is operating cash flow scaled by lagged total assets. $M B$ is market value of equity divided by total assets, which is a proxy for Tobin's Q. 


\section{REFERENCES}

Almeida, H., M. Campello, and M.S. Weisbach. 2004. The cash flow sensitivity of cash. The Journal of Finance LIX (4): 1777-1804.

Barua, A., L.F. Davidson, D.V. Rama, and S. Thiruvadi. 2010. CFO gender and accruals quality. Accounting Horizons 24 (1): 25-39.

Beatty, A., S. Liao, and J. Weber. 2008. Financial reporting quality, private information, monitoring and the lease-versus-buy decision. The Accounting Review 85 (4): 1215-1238.

Beatty, A., S. Liao, and J. J. Yu. 2013. The Spillover Effect of Fraudulent Financial Reporting on Peer Firms' Investments. Journal of Accounting and Economics

55: $183-205$.

Bens, D., and S. Monahan. 2004. Disclosure quality and the excess value of diversification. Journal of Accounting Research 42: 691-730.

Bens, D., and S. Monahan. 2008. Altering investment decisions to manage financial reporting outcomes: Asset-backed commercial paper conduits and FIN 46. Journal of Accounting Research 46 (5): 1017-1054.

Berle, A., Means, G., 1932. The Moder Corporation and Private Property. Macmillan, New York.

Biddle, G. C., C. M. Callahan, H. A. Hong and R. L. Knowles. 2011. Does mandatory adoption of international financial reporting standards increase investment efficiency? Working Paper.

, and G. Hilary. 2006. Accounting quality and firm level capital investment. The Accounting Review 81: 963-982.

, G. Hilary, and R.Verdi. 2009. How does financial reporting quality relate To investment efficiency? Journal of Accounting and Economics 48:112-131.

Bonsall IV, S., and Z. Bozanic. 2012. Ceteris paribus? Variable interest Entity (VIE) consolidation under FIN 46R. Working paper, The Ohio State University.

Bushman, R., and A. Smith. 2001. Financial accounting information and corporate governance. Journal of Accounting and Economics 31:237-333. 
Bushman, R., J. Piotroski, and A. Smith. 2011. Capital allocation and timely accounting recognition of economic losses: international evidence. Journal of Business, Finance and Accounting 38(1-2): 1-33.

Callahan, C. M., R. E. Smith, and A.W.Spencer.2012. Examination of the cost of capital implications of FIN 46. The Accounting Review 87 (4): 1105-1134.

, and

.2013. The valuation and reliability

implications of FIN 46 for synthetic lease liabilities. Journal of Accounting and

Public Policy 32: 271-291.

, and A.W.Spencer.2012. Risk implications of increased off-balance sheet disclosure: the case of FIN 46 and SOX. Accounting and Finance Research 1 (2): 126-138.

Chen, F., O. Hope, Q. Li, and X. Wang. 2011. Financial reporting quality and investment efficiency of private firms in emerging markets. The Accounting Review 86 (4): 1255-1288.

Cheng, M., D. Dhaliwal, and Y. Zhang. 2013. Does investment efficiency improve after the disclosure of material weaknesses in internal control over financial reporting? Journal of Accounting and Economics 56: 1-18.

Chi. W., L. L. Lisic, and M. Pevzner. 2011. Is enhanced audit quality associated with greater real earnings management? Accounting Horizons 25 (2): 315-335.

Danvers, K., A. Reinstein, and L. Jones. 2003. Financial performance effects of synthetic leases. Briefings in Real Estate Finance 3 (2), 131-146.

Dechow, P. 1994. Accounting earnings and cash flows as measures of firm performance: the role of accounting accruals. Journal of Accounting and Economics 18: 3-42.

Dechow, P., S. P. Kothari, and R. L. Watts. 1998. The relation between earnings and cash flows. Journal of Accounting and Economics 25: 133-168.

Fama, E., and K. French. 1997. Industry costs of equity. Journal of Finance 43: 153-193.

Dechow, P., and I. Dichev. 2002. The quality of accruals and earnings: the role of accrual estimation errors. The Accounting Review 77: 35-59.

, and C. Shakespeare. 2009. Do managers use securitization volume and fair value estimates to hit earnings targets? The Accounting Review 84 (1), 99-132. 
, W. Ge, and C. Schrand. 2010. Understanding earnings quality: a review for the proxies, their determinants and their consequences. Journal of Accounting and Economics 50: 344-401.

, L.A. Myers., and C. Shakespeare. 2010. Fair value accounting and gains from asset securitizations: A convenient earnings management tool with compensation side-benefits. Journal of Accounting and Economics 49: 2-25.

, Sloan, R., Sweeney, A., 1995. Detecting earnings management. The Accounting Review 70: 193-225.

Dickinson, V., M. Donohoe, and G. McGill. 2010. Clandestine accounting: variable interest entity consolidation, financial leverage and tax shelter participation. Working Paper, University of Mississippi, University of Illinois, and University of Florida.

Eisdorfer, A., C. Giaccotto, and R. White. 2013. Capital structure, executive compensation, and investment efficiency. Journal of Banking and Finance 37: 549-562.

Fazzari, S., R.G. Hubbard, and B.C. Petersen. 1988. Financial Constraint and Corporate Investment. Brookings Papers on Economic Activity: 141-195.

Feng, M., J. Gramlich, and S. Gupta. 2009. Special purpose vehicles: Empirical evidence on determinants and earnings management. The Accounting Review 84 (6): 18331876.

Financial Accounting Standards Board (FASB). 2003. Consolidation of Variable Interest Entities, an Interpretation of ARB No. 51. FASB Interpretation 46(R). Financial Accounting Series. Norwalk, CT: FASB.

Financial Accounting Standards Board (FASB). 2000b. Statement of financial accounting standards no. 140. Accounting for transfers and servicing of financial assets and extinguishments of liabilities.

Francis, J., R. LaFond, P. Olsson, and K. Schipper. 2005. The market pricing of accruals quality. Journal of Accounting and Economics 39 (2): 295-327.

Francis, J. R., and X. Martin. 2010. Acquisition profitability and timely loss recognition. Journal of Accounting and Economics 49: 161-178.

Gomariz, M. F. C., and J. P. S. Ballesta. 2014. Financial reporting quality, debt maturity and investment efficiency. Journal of Banking and Finance 40: 494-506. 
Gurun, U. G., A. Lerman, and J. Ronen. 2012. Anticipatory and implementation effects of FIN 46 on the behavior of different market participants. Asia-Pacific Journal of Accounting and Economics 19 (1): 30-55.

Hayashi, F., 1982. Tobin's marginal q and average q: a neoclassical interpretation. Econometrica 50: 213-224.

Hartgraves, A., and G.J. Benston 2002. Commentary: The evolving accounting standards for special purpose entities and consolidations. Accounting Horizons 16 (3): 245258.

Healy, P., and K. Palepu. 2001. Information asymmetry, corporate disclosure, and the capital markets: a review of the empirical disclosure literature. Journal of Accounting and Economics 31: 405-440.

Hunton, J., R. Libby, and C. Mazza. 2006. Financial reporting transparency and earnings management. The Accounting Review 81 (1): 135-157.

Jenson, M. C. 1986. Agency costs of free cash flow, corporate finance, and takeovers. American Economics Review 76 (May): 323-329.

Jensen, M., and W. Meckling. 1976. Theory of the Firm: Managerial Behavior, Agency Costs, and Capital Structure. Journal of Financial Economics 3: 305-360.

Jones, J., 1991. Earnings management during import relief investigations. Journal of Accounting Research 29, 193-228.

Kaplan, S. N., and L. Zingales. 1997. Do investment cash flow sensitivities provide useful measures of financing constraints? The Quarterly Journal of Economics February: 169-215.

Kothari, S.P., A. Leone, and C. Wasley. 2005. Performance matched discretionary accrual measures. Journal of Accounting and Economics 39: 163-197.

Lambert, R., C. Leuz, and R. Verrecchia. 2007. Accounting information, disclosure, and the cost of capital. Journal of Accounting Research 45: 385-420.

Leuz, C., and R. Verrecchia. 2000. The economic consequences of increased disclosure. Journal of Accounting Research 38: 91-124.

Lobo, G., and J. Zhou. 2001. Disclosure quality and earnings management. Asia-Pacic Journal of Accounting and Economics 8 (1): 1-20. 
Luo, T., and T. Warfield. 2014. The implementation effects of expanded consolidation: the case of consolidating special purpose entities. Accounting and Finance 54 (2): 539-566.

McNichols, M. 2002. Discussion of the quality of accruals and earnings: The role of accrual estimation errors. The Accounting Review 77 (Supplement): 61-69.

McNichols, M., and S. Stubben. 2008. Does earnings management affect firms' investment decisions? The Accounting Review 83: 1571-1603.

Moyen, N. 2004. Investment-cash flow sensitivities: constrained versus unconstrained firms. The Journal of Finance LIX 5: 2061-2092.

Myers, S. 1997. Determinants of corporate borrowing. Journal of Financial Economics 5: 147-175.

Myers,S., and N. Majluf. 1984. Corporate financing and investment decisions when firms have information that investors do not have. Journal of Financial Economics 13:187-221.

Opler,T., L. Pinkowitz, R. Stulz, and R. Williamson.1999. The determinants and implications of corporate cash holdings. Journal of Financial Economics 52: 346.

PricewaterhouseCoopers. 2004. Analysis of FIN 46: A Guide through the Maze. New York, NY: PricewaterhouseCoopers LLP.

Richardson, S. 2006. Over investment of free cash flow. Review of Accounting Studies 11: 159-189.

Shroff, N., R. S. Verdi, and G. Yu. 2014. Information Environment and the Investment Decisions of Multinational Corporations. The Accounting Review 89 (2): 759-790.

Soroosh, J., and J. Ciesielski. 2004. Accounting for special purpose entities revised: FASB Interpretation 46(R). The CPA Journal (July).

Stein, J. C. 2003. Agency,information and corporate investment. Handbook of the Economics of Finance 1 (1):111-165.

Verrecchia, R. 2001. Essays on disclosure. Journal of Accounting and Economics 32: 91180.

Williamson, O., 1974. Economics of discretionary behavior: managerial objectives in a theory of the firm. Kershar Publishing, London, UK. 
Yoshikawa, H. 1980. On the "q" theory of investment. American Economic Review 70: 739-743.

Zang, A.Y. 2012. Evidence on the trade-off between real activities manipulation and accrual-based earnings management. The Accounting Review 87 (2): 675-703.

Zhang, L. 2009. Economic consequences of recognizing off-balance sheet activities, Working paper, University of Washington. 


\section{APPENDIX}

\section{Variable Definitions}

Investment: the sum of research and development expenditure, capital expenditure, and acquisition expenditure less cash receipts from sale of property, plant, and equipment scaled by beginning total assets

SIZE: the $\log$ of total assets

$M B$ : market value of equity divided by total assets

Tangibility: property, plant and equipment divided by total assets

K-structure: long-term debt divided by the sum of long-term debt and the market value of equity

CFOsale: operating cash flow divided by sales

Slack: cash divided by property, plant and equipment

Dividend: indicator variable, 1 if the firm paid a dividend, 0 otherwise

OPCycle: operating cycle, the sum of 365 divided by inventory turnover and 365 divided by receivable turnover

Loss: indicator variable, 1 if net income before extraordinary items is negative, 0 otherwise

$R O A$ : income before extraordinary items divided by average total assets Leverage: total debts divided by total assets 
VITA

\title{
FANG ZHAO
}

\author{
Born, Tianjin, China
}

2006

B.B.A., Accounting and Financial Management Nanjing University

Nanjing, China

2008

M.A., Economics

University of Notre Dame

South Bend, Indiana

2010

M.S., Accounting

Indiana University South Bend

South Bend, Indiana

2014

Doctoral Candidate in Accounting

Florida International University

Miami, Florida 